\title{
AVALIAÇÃO DA PRODUÇÃO DE CAPIM TANZÂNIA EM AMBIENTE PROTEGIDO SOB DISPONIBILIDADE VARIÁVEL DE ÁGUA E NITROGÊNIO NO SOLO
}

\section{LEANDRO FELLET LOURENÇO}

\author{
Dissertação apresentada à Escola Superior de \\ Agricultura "Luiz de Queiroz”, Universidade \\ de São Paulo, para obtenção do título de \\ Mestre em Agronomia, Área de \\ Concentração: Irrigação e Drenagem.
}

P I R A C I C A B A

Estado de São Paulo - Brasil

Março - 2004 


\title{
AVALIAÇÃO DA PRODUÇÃO DE CAPIM TANZÂNIA EM AMBIENTE PROTEGIDO SOB DISPONIBILIDADE VARIÁVEL DE ÁGUA E NITROGÊNIO NO SOLO
}

\section{LEANDRO FELLET LOURENÇO \\ Engenheiro Agrônomo}

\section{Orientador: Prof. Dr. RUBENS DUARTE COELHO}

\author{
Tese apresentada à Escola Superior de \\ Agricultura "Luiz de Queiroz”, Universidade \\ de São Paulo, para obtenção do título de \\ Mestre em Agronomia, Área de \\ Concentração: Irrigação e Drenagem.
}

P I R A C I C A B A

Estado de São Paulo - Brasil

Março - 2004 


\title{
Dados Internacionais de Catalogação na Publicação (CIP) DIVSÃO DE BIBLIOTECA E DOCUMENTACÃO - ESALQ/USP
}

\author{
Lourenço, Leandro Fellet \\ Avaliação da produção de capim Tanzânia em ambiente protegido sob \\ disponibilidade variável de água e nitrogênio no solo / Leandro Fellet \\ Lourenço. - - Piracicaba, 2004. \\ $77 \mathrm{p}$. \\ 2004. \\ Dissertação (mestrado) - - Escola Superior de Agricultura Luiz de Queiroz, \\ Bibliografia. \\ 1. Capim Tanzânia 2. Deficiência hídrica 3. Estufa 4. Fertilizantes \\ nitrogenado 5. Irrigação I. Título \\ CDD 633.2
}

"Permitida a cópia total ou parcial deste documento, desde que citada a fonte - $\mathrm{O}$ autor" 


\author{
À minha noiva, Cristiane, \\ pela dedicação, apoio e estímulo, \\ e aos meus irmãos, Carolina e Rafael, \\ pelo carinho que sempre demonstraram,
}

\title{
Dedico
}

Aos meus pais, Bete e Luís Carlos (in memorian), pelo exemplo, carinho, dedicação e apoio que sempre demonstraram

Ofereço 


\section{AGRADECIMENTOS}

Ao Prof. Dr. Rubens Duarte Coelho, pelos ensinamentos oferecidos, pela orientação;

À minha família, em especial à minha mãe Bete pelo constante apoio e incentivo.

À minha noiva, Cristiane, pelo estímulo, paciência e compreensão durante todo o treinamento de mestrado.

Aos Professores do Departamento de Engenharia Rural: Prof. Décio Eugênio Cruciani, Prof. Marcos Vinícius Folegatti, Prof. José Antonio Frizzone, Prof. Tarlei Ariel Botrel, Prof. Sérgio Nascimento Duarte, pela confiança, apoio, orientação, ensinamentos proferidos e especialmente pela amizade;

Aos Professores Jarbas Honório de Miranda e Carlos Silveira Pedreira pela colaboração e incentivo;

Aos funcionários do Departamento de Engenharia Rural, Davilmar, Sandra, Gilmar, Hélio, César, Lino, em especial ao Sr. Anetonio pela colaboração na coleta de dados;

Ao magnífico grupo de estagiários GPID (Grupo de Prática em Irrigação e Drenagem), em especial ao Eng. Agr. Eduardo Bicego, ao Eng. Agr. Rafael Arruda pela dedicação, força de trabalho, respeito, alegria durante os serviços;

Aos amigos da República Pau-a-Pique, pelo companheirismo e histórias que ficarão para sempre;

À Escola Superior de Agricultura "Luiz de Queiroz” (ESALQ/USP), através do Departamento de Engenharia Rural, pelo apoio dispensado e pelo acolhimento;

Ao curso de Pós Graduação em Irrigação e Drenagem ESALQ/USP, pela oportunidade de fazer parte desta equipe;

Finalmente, a todos que contribuíram ou torceram pelo sucesso deste trabalho. 


\section{SUMÁRIO}

Página

LISTA DE FIGURAS ................................................................... vii

LISTA DE TABELAS …....................................................................... xii

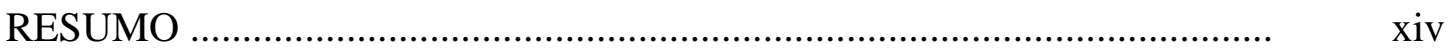

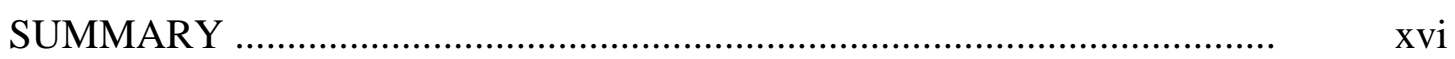

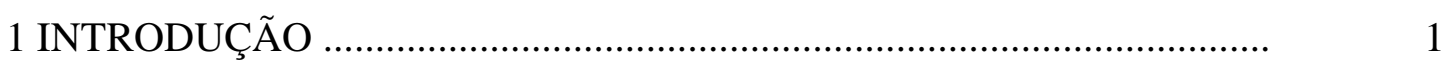

2 REVISÃO DE LITERATURA ...........................................................

2.1 O capim Tanzânia ............................................................................

2.2 Irrigação em pastagens .........................................................................

2.3 Adubação em pastagens .....................................................................

2.4 Modelos matemáticos para previsão da produção em função de variáveis climáticas ............................................................................... 11

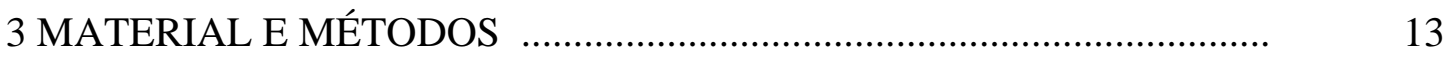

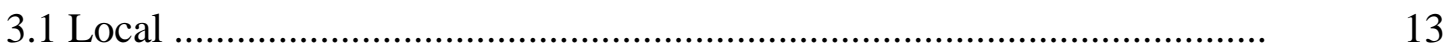

3.2 Área experimental ...................................................................... 13

3.3 Análise do solo, adubação de correção e plantio do capim ...................... 17

3.4 Tratamentos e delineamento experimental ............................................. 19

3.5 Sistema e condução da irrigação ........................................................... 20

3.6 Amostragem da forragem .............................................................. 20

3.7 Produção da forragem ......................................................................... 21

3.8 Eficiência do uso da água ................................................................. 22

3.9 Fator de resposta da cultura ................................................................. 23

3.10 Análise estatística ............................................................................. 24 
4. RESULTADOS E DISCUSSÃO …..................................................... 24

4.1 Dados meteorológicos ................................................................... 24

4.2 Lâmina de irrigação do capim Tanzânia ................................................. 27

4.3 Efeito da irrigação na produção de forragem ............................................ 31

4.4 Avaliação do efeito da adubação nitrogenada na produção de forragem . 33

4.5 Avaliação do efeito conjunto da irrigação e adubação nitrogenada na produção de forragem ..........................................................................

4.6 Estacionalidade de produção do capim Tanzânia .................................... 50

4.7 Coeficiente de resposta da cultura - ky ............................................... 52

4.8 Eficiência na utilização de água pelo capim Tanzânia ............................ 55

5 CONCLUSÕES ........................................................................ 59

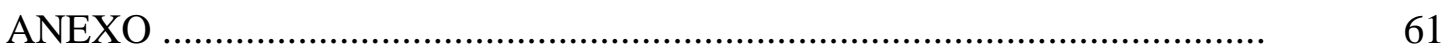

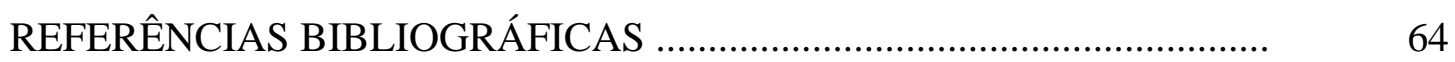




\section{LISTA DE FIGURAS}

Página

1 Croqui da área experimental indicando a disposição dos blocos ................ 14

2 Esquema de composição da caixa d’água de 500 l para os tratamento .......

3 Vista Geral do experimento durante a fase de crescimento do capim Tanzânia

4 Vista interna da área experimental durante o ciclo 3, com o capim Tanzânia emitindo sementes

5 Vista interna da área experimental durante o corte da forragem no ciclo 4.

6 Número ordinário dos tratamentos $\left(\mathrm{N}^{0}\right)$ em função do delineamento experimental dos tratamentos de adubação nitrogenada (DN) e lâmina de irrigação $(\mathrm{L})$............................................................................

7 Comparação da variação de temperatura média ao longo do período experimental e a temperatura média da normal

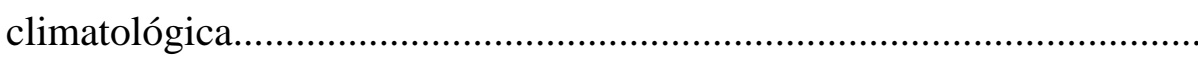

8 Comparação da variação de precipitação total ao longo do período experimental, a precipitação total da normal climatológica e a irrigação reposta no tratamento referência............................................................. 
9 Correlação entre a necessidade de irrigações do capim Tanzânia no tratamento $\mathrm{L}_{100}$ e a temperatura média do ciclo

10 Potencial mátrico do solo cultivado por capim Tanzânia, monitorado através de tensiômetros instalados a profundidade de 0,20 m para o período de crescimento de 30/10/02 a 18/10/03

11 Produção de forragem para o tratamento $0 \mathrm{~kg} \mathrm{~N}$ ciclo $^{-1}$ em função da lâmina de irrigação.............................................................................

12 Produção de forragem para o tratamento $30 \mathrm{~kg} \mathrm{~N}$ ciclo $^{-1}$ em função da lâmina de irrigação.................................................................................

13 Produção de forragem para o tratamento $60 \mathrm{~kg} \mathrm{~N}$ ciclo $^{-1}$ em função da lâmina de irrigação...............................................................................

14 Produção de forragem para o tratamento $110 \mathrm{~kg} \mathrm{~N}$ ciclo $^{-1}$ em função da lâmina de irrigação...............................................................................

15 Produção de forragem para o tratamento $270 \mathrm{~kg} \mathrm{~N}$ ciclo $^{-1}$ em função da lâmina de irrigação..............................................................................

16 Produção de forragem para o tratamento 25 \% ET da testem. em função da adubação nitrogenada

17 Produção de forragem para o tratamento 50 \% ET da testem. em função da adubação nitrogenada 
18 Produção de forragem para o tratamento 75 \% ET da testem. em função da adubação nitrogenada

19 Produção de forragem para o tratamento 100 \% ET da testem. em função da adubação nitrogenada

20 Produção de forragem para o tratamento 125 \% ET da testem. em função da adubação nitrogenada

21 Produção de forragem (t MS ha ${ }^{-1}$ ) do capim Tanzânia no ciclo 1 de 30/10 a 06/12/2002, para os tratamentos com lâmina de irrigação $L_{25}$, $\mathrm{L}_{50}, \mathrm{~L}_{75}, \mathrm{~L}_{100}$ e $\mathrm{L}_{125} \%$ da $\mathrm{ET}_{\text {Testemunha }}$ em comparação com as doses de adubação nitrogenada $\left(\mathrm{D}_{0}, \mathrm{D}_{30}, \mathrm{D}_{60}, \mathrm{D}_{110}\right.$ e $\mathrm{D}_{270} \mathrm{~kg} \mathrm{~N} \mathrm{ha}^{-1}$ ciclo $\left.^{-1}\right)$..........

22 Produção de forragem (t MS ha ${ }^{-1}$ ) do capim Tanzânia no ciclo 2 de 07/12/2002 a 10/01/2003, para os tratamentos com lâmina de irrigação $\mathrm{L}_{25}, \mathrm{~L}_{50}, \mathrm{~L}_{75}, \mathrm{~L}_{100}$ e $\mathrm{L}_{125} \%$ da $\mathrm{ET}_{\text {Testemunha }}$ em comparação com as doses de adubação nitrogenada $\left(\mathrm{D}_{0}, \mathrm{D}_{30}, \mathrm{D}_{60}, \mathrm{D}_{110}\right.$ e $\mathrm{D}_{270} \mathrm{~kg} \mathrm{~N} \mathrm{ha}^{-1}$ ciclo $\left.^{-1}\right) . . . .$.

23 Produção de forragem (t MS ha ${ }^{-1}$ ) do capim Tanzânia no ciclo 3 de 11/01 a 15/02/2003, para os tratamentos com lâmina de irrigação $L_{25}$, $\mathrm{L}_{50}, \mathrm{~L}_{75}, \mathrm{~L}_{100}$ e $\mathrm{L}_{125} \%$ da $\mathrm{ET}_{\text {Testemunha }}$ em comparação com as doses de adubação nitrogenada $\left(\mathrm{D}_{0}, \mathrm{D}_{30}, \mathrm{D}_{60}, \mathrm{D}_{110}\right.$ e $\mathrm{D}_{270} \mathrm{~kg} \mathrm{~N} \mathrm{ha}^{-1}$ ciclo $\left.{ }^{-1}\right)$..........

24 Produção de forragem (t MS ha ${ }^{-1}$ ) do capim Tanzânia no ciclo 4 de 16/02 a 22/03/2003, para os tratamentos com lâmina de irrigação $L_{25}$, $\mathrm{L}_{50}, \mathrm{~L}_{75}, \mathrm{~L}_{100}$ e $\mathrm{L}_{125} \%$ da $\mathrm{ET}_{\text {Testemunha }}$ em comparação com as doses de adubação nitrogenada $\left(\mathrm{D}_{0}, \mathrm{D}_{30}, \mathrm{D}_{60}, \mathrm{D}_{110}\right.$ e $\mathrm{D}_{270} \mathrm{~kg} \mathrm{~N}$ ha $^{-1}$ ciclo $\left.^{-1}\right)$.......... 
Página

25 Produção de forragem (t MS ha ${ }^{-1}$ ) do capim Tanzânia no ciclo 5 de 23/03 a 26/04/2003, para os tratamentos com lâmina de irrigação $L_{25}$, $\mathrm{L}_{50}, \mathrm{~L}_{75}, \mathrm{~L}_{100}$ e $\mathrm{L}_{125} \%$ da $\mathrm{ET}_{\text {Testemunha }}$ em comparação com as doses de adubação nitrogenada $\left(\mathrm{D}_{0}, \mathrm{D}_{30}, \mathrm{D}_{60}, \mathrm{D}_{110}\right.$ e $\mathrm{D}_{270} \mathrm{~kg} \mathrm{~N}$ ha $^{-1}$ ciclo $\left.^{-1}\right)$..........

26 Produção de forragem (t MS ha ${ }^{-1}$ ) do capim Tanzânia no ciclo 6 de 27/04 a 31/05/2003, para os tratamentos com lâmina de irrigação $L_{25}$, $\mathrm{L}_{50}, \mathrm{~L}_{75}, \mathrm{~L}_{100}$ e $\mathrm{L}_{125} \%$ da $\mathrm{ET}_{\text {Testemunha }}$ em comparação com as doses de adubação nitrogenada $\left(\mathrm{D}_{0}, \mathrm{D}_{30}, \mathrm{D}_{60}, \mathrm{D}_{110}\right.$ e $\mathrm{D}_{270} \mathrm{~kg} \mathrm{~N}$ ha $^{-1}$ ciclo $\left.^{-1}\right)$..........

27 Produção de forragem (t MS ha ${ }^{-1}$ ) do capim Tanzânia no ciclo 7 de 01/06 a 05/07/2003, para os tratamentos com lâmina de irrigação $L_{25}$, $\mathrm{L}_{50}, \mathrm{~L}_{75}, \mathrm{~L}_{100}$ e $\mathrm{L}_{125} \%$ da $\mathrm{ET}_{\text {Testemunha }}$ em comparação com as doses de adubação nitrogenada $\left(\mathrm{D}_{0}, \mathrm{D}_{30}, \mathrm{D}_{60}, \mathrm{D}_{110}\right.$ e $\mathrm{D}_{270} \mathrm{~kg} \mathrm{~N}$ ha $^{-1}$ ciclo $\left.^{-1}\right)$..........

28 Produção de forragem (t MS ha ${ }^{-1}$ ) do capim Tanzânia no ciclo 8 de 06/07 a 09/08/2003, para os tratamentos com lâmina de irrigação $L_{25}$, $\mathrm{L}_{50}, \mathrm{~L}_{75}, \mathrm{~L}_{100}$ e $\mathrm{L}_{125} \%$ da $\mathrm{ET}_{\text {Testemunha }}$ em comparação com as doses de adubação nitrogenada $\left(\mathrm{D}_{0}, \mathrm{D}_{30}, \mathrm{D}_{60}, \mathrm{D}_{110}\right.$ e $\mathrm{D}_{270} \mathrm{~kg} \mathrm{~N} \mathrm{ha}^{-1}$ ciclo $\left.^{-1}\right)$.

29 Produção de forragem (t MS ha ${ }^{-1}$ ) do capim Tanzânia no ciclo 9 de 10/08 a 13/09/2003, para os tratamentos com lâmina de irrigação $L_{25}$, $\mathrm{L}_{50}, \mathrm{~L}_{75}, \mathrm{~L}_{100}$ e $\mathrm{L}_{125} \%$ da $\mathrm{ET}_{\text {Testemunha }}$ em comparação com as doses de adubação nitrogenada $\left(\mathrm{D}_{0}, \mathrm{D}_{30}, \mathrm{D}_{60}, \mathrm{D}_{110}\right.$ e $\mathrm{D}_{270} \mathrm{~kg} \mathrm{~N}$ ha $^{-1}$ ciclo $\left.^{-1}\right)$..........

30 Produção de forragem (t MS ha ${ }^{-1}$ ) do capim Tanzânia no ciclo 10 de 14/09 a 18/10/2003, para os tratamentos com lâmina de irrigação $L_{25}$, $\mathrm{L}_{50}, \mathrm{~L}_{75}, \mathrm{~L}_{100}$ e $\mathrm{L}_{125} \%$ da $\mathrm{ET}_{\text {Testemunha }}$ em comparação com as doses de adubação nitrogenada $\left(\mathrm{D}_{0}, \mathrm{D}_{30}, \mathrm{D}_{60}, \mathrm{D}_{110}\right.$ e $\mathrm{D}_{270} \mathrm{~kg} \mathrm{~N}$ ha $^{-1}$ ciclo $\left.^{-1}\right)$.......... 
31 Comparação da produção de matéria seca (t MS ha ${ }^{-1}$ ) nos 10 ciclos de corte da forragem para os tratamentos com a mesma lâmina de irrigação $\mathrm{L}_{25}, \mathrm{~L}_{50}, \mathrm{~L}_{75}, \mathrm{~L}_{100}$ e $\mathrm{L}_{125} \%$ da $\mathrm{ET}_{\text {Testemunha }}$ em comparação com as doses

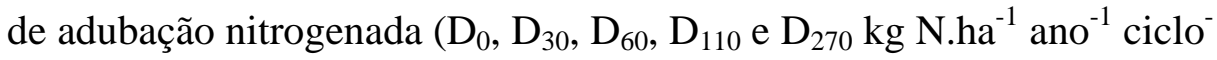
$\left.{ }^{1}\right)$.

32 Isolinhas da produção de forragem em capim Tanzânia em função do ciclo e quantidades de água e nitrogênio 


\section{LISTA DE TABELAS}

1 Análises químicas em amostras de solo na camada de $0-40 \mathrm{~cm}$ em

Página latossolo vermelho amarelo, utilizado no preenchimento das caixas.

2 Análise granulométrica em amostras de solo em latossolo vermelho amarelo, na profundidade $0-40 \mathrm{~cm}$, utilizado no preenchimento das caixas.

3 Período de crescimento do capim Tanzânia, temperatura média, chuva efetiva, irrigação $\left(\mathrm{T}_{100}\right)$ e saldo hídrico......................................................

4 Lâmina de irrigação aplicada nos ciclos do capim Tanzânia em função dos tratamentos.

5 Média de produção de forragem do capim Tanzânia nas 4 repetições (t MS ha ${ }^{-1}$ ), em função dos níveis de adubação nitrogenada e deficiência hídrica, em diferentes períodos de coleta...................................................

6 Modelo matemático de ajuste de superfície de resposta ao comportamento da produção de forragem do capim Tanzânia submetido a lâminas de irrigação e doses de adubação em 10 ciclos com os respectivos valores do coeficiente de correlação $\left(\mathrm{r}^{2}\right)$ e valor $\mathrm{F}$ 
7 Produção de forragem no período de verão (ciclos 1, 2, 3, 4 e 10) e inverno (ciclos 5, 6, 7, 8 e 9) em capim Tanzânia........................................

8 Coeficiente de resposta da cultura (ky) para capim Tanzânia submetido a diferentes doses de adubação nitrogenada...................................................

9 Média das EUA determinadas para diferentes lâmina de irrigação em capim Tanzânia, durante o período experimental 


\title{
AVALIAÇÃO DA PRODUÇÃO DE CAPIM TANZÂNIA EM AMBIENTE PROTEGIDO SOB DISPONIBILIDADE VARIÁVEL DE ÁGUA E NITROGÊNIO NO SOLO
}

\author{
Autor: LEANDRO FELLET LOURENÇO \\ Orientador: Prof. Dr. RUBENS DUARTE COELHO
}

\section{RESUMO}

O objetivo deste trabalho foi analisar a produtividade do capim Panicum maximum Jacq cv Tanzânia cultivado em casa de vegetação sob tratamentos de lâmina de irrigação e adubação nitrogenada durante 10 ciclos de produção (10 x 35 dias) na região de Piracicaba-SP. O capim foi cultivado em ambiente protegido sob os seguintes tratamentos: a) lâmina de irrigação $\mathrm{L}_{25}, \mathrm{~L}_{50}, \mathrm{~L}_{75}, \mathrm{~L}_{100}$ e $\mathrm{L}_{125} \%$ da Evapotranspiração da Testemunha e doses de nitrogênio $\mathrm{D}_{0}, \mathrm{D}_{30}, \mathrm{D}_{60}, \mathrm{D}_{110}$ e $\mathrm{D}_{270} \mathrm{~kg} \mathrm{~N}_{\mathrm{Na}}{ }^{-1}$ ciclo ${ }^{-1}$, totalizandose 25 tratamentos distribuídos em 4 blocos. Observou-se que os tratamentos sem deficiência hídrica apresentaram diferença significativa na produtividade de forragem nos ciclos de verão e não significativa nos ciclos de inverno. A estacionalidade de produção do capim Tanzânia (verão / inverno) foi praticamente equivalente (65 / 35\%) nos tratamentos intermediários de irrigação (50, 75 e 100\%), para os tratamentos extremos de irrigação 25 e 125\%, a estacionalidade de produção aumentou: 67 / 33 \% e 75 / 25\%, respectivamente. O coeficiente de resposta da cultura à deficiência hídrica 
(ky) variou entre 0,75 e 0,80. A eficiência de utilização da água do capim Tanzânia foi de 36,0 e 16,6 $\mathrm{kg} \mathrm{MS} \mathrm{mm}^{-1} \mathrm{ha}^{-1}$ respectivamente para os tratamentos $\mathrm{L}_{25}$ e $\mathrm{L}_{125}$. Com base no modelo matemático ajustado é possível estimar a produção do capim Tanzânia em função da disponibilidade de água e nitrogênio para a região de Piracicaba - SP. 


\title{
EVALUATION OF Panicum maximum Jacq. cv Tanzânia PRODUCTION UNDER RAINFALL CONTROLLED CONDITIONS ACCORDING TO WATER AND NITROGEN AVALIABILITY IN SOIL
}

\author{
Author: LEANDRO FELLET LOURENÇO \\ Adviser: Prof. Dr. RUBENS DUARTE COELHO
}

\section{SUMMARY}

The objective of this work was to analyze the productivity of the grass Panicum maximum Jacq cv Tanzania during 10 growing cycles (10 x 35 days) in the region of Piracicaba-SP. The grass was cultivated under rainfall controlled conditions, subjected to the following treatments: a) irrigation depths L25, L50, L75, L100 and L125\% of the control plot (field capacity condition - 100\%) and nitrogen doses D0, D30, D60, D110 and D270 kg N ha ${ }^{-1}$ cycle $^{-1}$, totalizing 25 treatments distributed among 4 blocks. It was observed that the treatments without water deficit had presented significant difference in the productivity of the forage plant during summer growing cycles and not significant difference during winter growing cycles. The irrigation did not modify the effect of the seasonal pattern of forage production and in fact had aggravated if in the treatments with more intensive fertilization.The seasonal pattern of forage production (summer / winter) 
was equivalent (65 / 35\%) in the intermediated irrigation treatments (50, 75 and 100\%), for the extreme irrigation treatments (25 and 125\%) it was observed an increase in the seasonal pattern 67 / 33\% and 75 / 25, respectively. The pasture coefficient of reply (ky) to water deficit varied between 0,75 and 0,80 . The Tanzania grass efficiency of water use was of 36,0 and 16,6 kg MS mm${ }^{-1}$ ha ${ }^{-1}$ respectively for the treatments $\mathrm{L}_{25}$ and $\mathrm{L}_{125}$. 


\section{INTRODUÇÃO}

A produção estacional de pastagem, associada diretamente ao período denominado "inverno" que apresenta distribuição irregular de chuvas, temperatura do ar e fotoperíodo, tendo influência direta na produção do rebanho bovino brasileiro, que possui o maior rebanho comercial do mundo com 162 milhões de cabeças, cerca de 15\% do total mundial (Anualpec, 2001). Como conseqüência dessa má distribuição da produção de matéria seca ao longo do ano, os rebanhos criados exclusivamente a pasto apresentam no inverno perda de peso, reprodução irregular, crescimento retardado e quebra de produção de leite. A ocupação das pastagens passa a ser regulada pela disponibilidade de alimentos no período de menor disponibilidade (inverno), considerando que boa parte dos pecuaristas utiliza o pasto como base de alimentação de seus animais com pouca ou nenhuma alimentação complementar (Faria \& Corsi, 1986).

Como alternativas para o pecuarista enfrentar o período de estiagem adota-se as seguintes alternativas: deixar os animais perderem peso durante a estação seca (na esperança de que o mesmo seja recuperado de forma compensatória durante a estação das chuvas); reservar parte da área de pastagem para ser usada durante a estação seca; controlar as parições e vendas de animais, reduzindo o tamanho do rebanho (de forma a harmonizar as exigências nutricionais com a disponibilidade de nutrientes). Estas atitudes são as mais populares, sendo responsáveis pelo longo período necessário para produzir um animal estritamente a pasto para o abate.

Porém, com a intensificação agrícola ocorrida nos últimos anos, houve valorização na terra, pressionando os pecuaristas a melhorar os índices de produtividade, adotando inovações tecnológicas através de diferentes técnicas, como a conserva de 
alimentos na forma de feno e silagem para confinar os bovinos no período em que a disponibilidade é limitada, usando resíduos e subprodutos da agricultura e agroindústria e, irrigação, adubação e rotação de pastagens.

Com o recente incentivo para exportação brasileira, com aumento da demanda internacional de carne bovina, principalmente após a identificação da síndrome da "Vaca Louca” em países da Europa e América do Norte, o suprimento adequado, para atender a grande demanda do mercado futuro no Brasil dependerá da modernização da atividade produtiva, com intensificação dos sistemas de produção. O processo de modernização pode contribuir com o aumento da produção por unidade animal e por unidade de área, levando em conta desde o fornecimento de dietas para animais confinados nos períodos de estacionalidade de produção até sistemas baseados exclusivamente em pastagens.

Todavia, o aumento da taxa de lotação animal em pastagens traz risco maior ao empreendimento pecuário, existindo a necessidade de haver maior produção de forragem para sustentar altas taxas de lotação, porém, haverá dependência das incertas variáveis climáticas, como a quantidade e a distribuição de chuvas. A água é o nutriente mais importante controlando a produtividade das pastagens (Jarvis el at., 1995). Dessa maneira, variações no volume de água disponível no solo para o crescimento da cultura, principalmente quando as taxas de lotação animal na propriedade são elevadas (> 3 UA $\mathrm{ha}^{-1}$ ), determinam maiores oscilações no ganho de peso individual dos animais em pastejo, no retorno econômico da atividade e, conseqüentemente, uma maior freqüência e magnitude de perda econômica (Parsch et al., 1997).

Já foram realizados uma série de trabalhos com o objetivo de estudar o comportamento do capim Tanzânia irrigado, conduzindo de forma rotacionado em Piracicaba e outras regiões do Brasil. O experimento conduzido por Soria (2002), estudando irrigação e adubação nitrogenada à campo, não observou efeito significativo na produção do capim Tanzânia no ano de 2001, desta forma, o presente trabalho de pesquisa teve como objetivo complementar os estudos já realizados, avaliando os efeitos da irrigação e deficiências hídricas em conjunto com a adubação nitrogenada na produção do capim Tanzânia em condição de ambiente protegido. 


\section{REVISÃO DE LITERATURA}

\subsection{O capim Tanzânia}

A produção pecuária do Brasil tropical se apóia em pastagens de gramíneas. Dentre elas, as da espécie Panicum maximum Jacq ocupam lugar de destaque, especialmente em áreas com solos de fertilidade elevada (Vieira \& Kichel, 1995).

O gênero Panicum caracteriza-se por possuir grande variabilidade genética e morfológica, além do cultivar mais conhecida no Brasil, capim colonião, têm-se também as seguintes cultivares: Búfalo, Colonião Deodoro, Colonião de Tanganica, Colonião sul-africano, Coloninho, Gatton panic, Green panic, Guiné, Guinezinho, Makueni, Tobiatã, Mombaça e Tanzânia (Aronovich, 1995). É constituída por espécies com hábito de crescimento ereto e rizomatoso, por plantas tolerantes ao encharcamento, por ecotipos que exigem solo com fertilidade moderada a alta, tolerantes ao alumínio e com reprodução apomítica e sexuada (Corsi, 1988).

O capim Tanzânia (BRA-007218) foi coletado pelo "Instituit Français de Recherche Scientifique pour lê Développement em Coopération” (ORSTOM) em Korogwe, na Tanzânia. O lançamento comercial desse capim em 1990, foi fruto de um longo trabalho de seleção coordenado pela Embrapa (Jank et al., 1995).

O potencial de utilização deste capim pode ser verificado através dos resultados obtidos durante a avaliação dos acessos no banco de germoplasma da Embrapa Gado de Corte. O capim Tanzânia Produziu $33 \mathrm{t} \mathrm{ha}^{-1} \mathrm{ano}^{-1}$ de matéria seca total, sendo $26 \mathrm{t} \mathrm{ha}{ }^{-1}$ ano $^{-1}$ de matéria seca foliar (80\%), e teve, em média 12,7\% de proteína bruta nas folhas e 9\% nos colmos (Jank et al., 1995). 
O capim Tanzânia apresenta algumas características que variam conforme o tipo de manejo adotado e que determinam a sua estrutura. Dentre essas características, o índice de área foliar (IAF) tem papel fundamental e é reconhecido como a principal característica estrutural do pasto. Quanto maior o IAF do pasto, maior a quantidade de luz interceptada pelo dossel, o que assegura maior produtividade fotossintética e, portanto, maior produção de matéria seca (Fagundes et al., 1999).

O capim Tanzânia apresenta elevada estacionalidade de produção. A taxa de acúmulo de matéria seca aumentou de $80 \mathrm{~kg}$ de $\mathrm{MS} \mathrm{ha}^{-1} \mathrm{dia}^{-1}$ em setembro/novembro para $100 \mathrm{~kg} \mathrm{MS} \mathrm{ha}^{-1} \mathrm{dia}^{-1}$ em janeiro/fevereiro, voltando a diminuir para $96 \mathrm{~kg} \mathrm{MS} \mathrm{ha-1}$ $\mathrm{dia}^{-1}$ em fevereiro/abril (Santos et al., 1999). Em experimento conduzido por Cecato et (1996), onde os cortes eram feitos a cada 35 dias no verão e 70 no inverno, a produção por corte no verão foi de $7.400 \mathrm{~kg} \mathrm{ha}^{-1}$ e no inverno de $2.700 \mathrm{~kg} \mathrm{ha}^{-1}$. Essa variação no nível de produção de matéria seca ao longo do ano é um dos motivos para a baixa produtividade observada em algumas áreas.

\subsection{Irrigação em pastagens}

Em situações déficit hídrico, as plantas apresentam mecanismos de aclimatação genética, alterando o padrão de distribuição de carboidratos (osmoregulação), direcionando-os para regiões mais prioritárias (sistema radicular). Schulz (1994) observou em pisum sativum L. aumento na translocação de carboidratos para células da raiz em resposta ao baixo potencial hídrico no solo. Por outro lado, o esforço realizado na expansão do sistema radicular evita que a planta morra, mas ocorre uma resposta antagônica em relação ao desenvolvimento vegetativo (área foliar) e a superfície de transpiração (Kalapos et al., 1996).

A forma de se evitar que as gramíneas tenham redução de produção pelo efeito da deficiência hídrica é através da técnica de irrigação. Segundo Soria (2002), a irrigação em pastagens tem sido utilizada como elemento regulador da produção e como instrumento para diminuir o efeito da estacionalidade. 
Ghelfi Filho (1972) foi um dos pioneiros, no Brasil, a avaliar a prática da irrigação em pastagem, estudando capim Elefante (Pennisetum purpureum, Schum.), observou aumento na produtividade no período seco em $26 \%$, quando comparado com a testemunha, não alterando o efeito estacional das gramíneas. Ghelfi Filho (1976) comenta que, embora os valores relativos (incremento percentual em relação à testemunha não irrigada) e absolutos (quantidade adicional de MS produzida em relação à testemunha não irrigada) da produção de forragem tenham sido significativamente aumentados pelo uso da irrigação nesse experimento, a estacionalidade da produção forrageira não foi alterada de maneira sensível na região de Piracicaba - SP .

Segundo Cooper (1970); citado por Corsi e Nascimento Júnior (1994) a falta estacional de água é um dos mais importantes fatores climáticos, limitando a produção de forragens nos trópicos e subtrópicos. Os mesmos autores enfatizam que até plantas que crescem em solos mantidos próximos ao teor de água correspondente à capacidade de campo podem desenvolver déficit hídrico quando as condições ambientais são favoráveis à elevadas taxas de evapotranspiração e, nessas condições, Turner e Begg (1978) esclarecem que o nível de água no solo só tem a finalidade de estabelecer os limites de recuperação da planta durante o período noturno.

Maldonado et al. (1997), estudando o capim elefante irrigado (Pennisetum purpureum), observaram efeito linear da produção de matéria seca em função da lâmina de água aplicada, no período de inverno. Os autores relatam que a deficiência hídrica na região, nos meses de maio a setembro, limita a produção forrageira de forma drástica, enquanto fatores como temperatura e luminosidade permanecem dentro de um padrão adequado para produção de plantas tropicais.

A eliminação da deficiência hídrica no período da seca, foi inicialmente considerada nos trabalhos de pesquisa, como responsável pela estacionalidade de produção das plantas forrageiras. Após alguns experimentos realizados com irrigação em pastagem observou-se a persistência da estacionalidade de produção. Este fato indica que outros fatores, que não a água, influenciam no desenvolvimento do capim no período da seca, como a temperatura (Coorper \& Tainton, 1968; Muller, 2000) e o fotoperíodo (Mannetje \& Pritchard, 1974; Villa Nova et al., 1999. 
Embora limitações de temperatura e de fotoperíodo invariavelmente limitem a produção de forragem no inverno, Rassini (2002) mostrou que a irrigação do capim Tanzânia melhorou a distribuição de forragem ao longo do ano. Sem irrigação, a produção de forragem foi de 4,1 $\mathrm{t} \mathrm{ha}^{-1}$ de MS nas estações de outono/inverno (21\% da produção anual), enquanto que o uso de irrigação elevou a produção de forragem no período para 11,7 t ha ${ }^{-1}$ de MS (34,6 \% da produção anual).

A comparação entre estudo de pastejo com o capim Tanzânia também indica efeitos positivos da irrigação durante a época seca. Experimentos realizados em condição de sequeiro, com níveis moderados de nitrogênio $\left(<100 \mathrm{~kg} \mathrm{ha}^{-1} \mathrm{ano}^{-1}\right.$ de $\left.\mathrm{N}\right)$, mostraram que a taxa de lotação durante a seca variou de 1,0 a 1,8 UA ha ${ }^{-1}$ (Euclides et al., 2001). Entretanto, em avaliação com o capim Tanzânia irrigado e adubado com níveis elevados de nitrogênio (80 $\mathrm{kg} \mathrm{ha}^{-1} \mathrm{ano}^{-1}$ de $\mathrm{N}$ em cada ciclo de pastejo), na seca, a taxa de lotação animal média foi de 3,7 UA ha-1 (Penati, 2002). Em fazendas comerciais, taxas de lotação da ordem de 3,5 UA ha ${ }^{-1}$, em pastagem de capim Tanzânia, têm sido relatadas no período do inverno (Corsi \& Martha Júnior, 1998).

O trabalho de Maya (2003), com o capim Tanzânia, não indicou efeitos favoráveis da irrigação na seca sobre a taxa de lotação animal, que foi de 1,9 UA ha ${ }^{-1}$ nas condições de sequeiro e de 2,1 UA ha ${ }^{-1}$ com o uso da irrigação. Nesse experimento as adubações nitrogenadas foram feitas apenas durante o período das águas. Todavia, podese inferir que resultados mais positivos da irrigação sobre a produção de forragem durante a época seca do ano e, conseqüentemente, sobre a taxa de lotação animal em pastagens irrigadas, são dependentes da adubação nitrogenada, conforme indicado no trabalho de Vilela et al. (2003).

Na literatura atual, os trabalhos científicos abordam a comparação entre áreas irrigadas e de sequeiro, sendo escassas informações sobre o efeito da água no rendimento das culturas. Em experimento realizado por Soria (2002) foi avaliado o comportamento do capim Tanzânia em função de diferentes lâminas de irrigação e adubação nitrogenadas na região de Piracicaba - SP e, segundo o autor, não foi observado efeito significativo na produção do capim em função das lâminas de irrigação 
devido ao clima regional apresentar períodos de temperaturas baixas e deficiência hídrica coincidente.

\subsection{Adubação em pastagens}

Grande parte das pastagens no Brasil encontra-se estabelecida em solo de baixa fertilidade química, com características restritivas ao crescimento vegetal (acidez elevada e níveis tóxicos de alumínio e de manganês) e/ou com baixa capacidade de fornecer nutrientes para o crescimento da planta forrageira, desta forma, a produção de forragem em solos tropicais, na ausência de uso de corretivos e fertilizantes, é bastante aquém do potencial de produção das gramíneas tropicais (Martha Júnior \& Vilela, 2002).

Entre os fatores que influem no valor nutritivo da planta forrageira está a disponibilidade dos nutrientes no solo e, também, suas interações. Para a produção ser efetiva, todos os outros nutrientes devem estar presentes em quantidades adequadas e equilibradas (Monteiro e Werner 1977). Além disso, a quantidade de nutrientes extraída do solo pela planta forrageira será maior quanto maior for a produção de forragem (Werner et al., 1996).

As gramíneas utilizadas em pastagens no Brasil, mesmo as mais rústicas e menos exigentes em fertilidade do solo, normalmente respondem bem à adubação. Mesmo assim, na maior parte das propriedades dedicadas à pecuária a exploração das pastagens é conduzida com pouco ou nenhum uso de corretivos e fertilizantes, em sistemas com baixa taxa de lotação. Adubações conservadoras são adequadas a maioria dos pecuaristas para melhorar significativamente o uso das pastagens, garantindo retorno econômico satisfatório, sem implicar em grandes investimentos. No entanto, sistemas de produção com maior intensificação na capacidade de produção, podem optar por um manejo intensivo das forrageiras e aproveitar as altas respostas das gramíneas à adubação (Cantarella et al., 2002). 
Corsi \& Nussio, (1988) comentam que a necessidade de calagem não deve ser subestimada em áreas adubadas com $\mathrm{N}$, com recomendação de calagem visando elevar o valor da saturação a cerca de 70 a 80 \%, apesar da relativa tolerância das gramíneas às condições de acidez do solo. Segundo Vicente-Chandler et al. (1983), a maioria das fontes nitrogenadas exerce efeito de acidificação sobre o solo devido a nitrificação e lixiviação das bases que acompanham o nitrato, desta forma, em pastagens adubadas com $\mathrm{N}$ e que não recebem calcário podem se deteriorar em médio prazo.

A deficiência do fósforo (P) nos solos brasileiros é generalizada o que limita o estabelecimento e a produtividade das pastagens, além de afetar negativamente a qualidade da forragem produzida. Nesta situação a adubação fosfatada é fundamental, principalmente em sistemas intensivos de produção, para não limitar a resposta da planta forrageira quando são utilizados níveis elevados de nitrogênio (Cantarella et al., 2002). Monteiro e Werner (1977) observaram em capim colonião, que a adubação fosfatada é mais importante na fase inicial do estabelecimento da gramínea e o nitrogênio é mais requerido após o desenvolvimento inicial, incrementando a produção de forragem e o teor de proteína bruta. Paulino (1990) notou que a calagem aumentou a eficiência do fósforo, melhorou a disponibilidade de molibdênio, resultando em maior acúmulo desse elemento na parte aérea, e também aumentou a produção de forragem em conjunto com a adubação fosfatada.

Corrêa et al. (1996) em estudo nos solos de cerrado de baixa fertilidade, avaliaram quatro cultivares de P. maximum (Tanzânia, Mombaça, Vencedor e Massai), verificaram resposta acentuada das plantas às doses de $\mathrm{P}$ aplicadas. $\mathrm{A}$ dose de $\mathrm{P}$ associada a $80 \%$ da produção máxima foi de $223 \mathrm{~kg}$ de $\mathrm{P}_{2} \mathrm{O}_{5}$ ha $^{-1}$, sendo semelhante para as quatro cultivares. O nível crítico de P-resina no solo foi de $21 \mathrm{mg} \mathrm{dm}^{-3}$ e na forragem de $2,3 \mathrm{~g} \mathrm{~kg}^{-1}$.

A essencialidade do $\mathrm{N}$ da produtividade da planta forrageira reflete a influência sobre aspectos morfológicos, em razão da participação desse elemento, por exemplo, na estrutura de proteínas, de clorofila e de carreadores que participam de processos fisiológicos no vegetal (Martha Júnior, 2003), interferindo positivamente na capacidade fotossintética da planta e na recuperação da área foliar após a desfolha. Para $P$. 
maximum, tem sido caracterizado que o aumento da disponibilidade de $\mathrm{N}$ no meio interfere positivamente sobre os fatores que estimulam o crescimento acelerado da planta forrageira e, conseqüentemente, contribuem para o aumento da produtividade da pastagem, como a mobilização de reservas (C e N) na planta após a desfolha (Corsi, 1984), a expansão da área foliar (Mello, 2002) e o aumento no número de perfilhos (Santos, 2002).

Desta forma, uma das peças chaves para elevar a produtividade de forragem e conseqüentemente o número de unidades animais por área, é o uso da adubação nitrogenada, que parece apresentar resposta linear na produção com o aumento na aplicação de nitrogênio até níveis de $1.800 \mathrm{~kg} \mathrm{~N} \mathrm{ha}^{-1}$ observado em um dos estudos pioneiros Vicente-Chandler, (1973) na América Central. No Brasil foram encontradas respostas marcantes a adubação nitrogenada, com os maiores incrementos de produção situados na faixa de 300 a $400 \mathrm{~kg} \mathrm{ha}^{-1}$ de N por ano (Werner et al., 1967; Corsi, 1986; Soria, 2002).

Primavesi et al., 2001b em estudo com o capim coastcross (Cynodon dactylon) observou o potencial de resposta ao $\mathrm{N}$ com a produção de forragem em 5 cortes elevando de $4 \mathrm{t} \mathrm{ha}^{-1}$ testemunha para $19 \mathrm{t} \mathrm{ha}^{-1}$ quando foram aplicados $1000 \mathrm{~kg} \mathrm{ha}^{-1} \mathrm{de}$ N. O mesmo autor comenta ainda que nem sempre as plantas conseguirem incorporar todo $\mathrm{N}$ absorvido quando são utilizadas doses altas, especialmente se o intervalo entre cortes ou pastejo for curto, havendo acúmulo significativo de nitrato nas plantas tratadas com $200 \mathrm{~kg} \mathrm{ha}^{-1}$ de $\mathrm{N}$ por corte. $\mathrm{O} \mathrm{N}$ que excede as necessidades de crescimento das plantas geralmente é acumulado nos vacúolos na forma de nitrato, o qual não é praticamente aproveitado pelo animal e pode até ter efeito tóxico para bovinos, quando os níveis de nitrato na matéria seca da forragem forem de 2,3 a 4,3 $\mathrm{g} \mathrm{kg}^{-1}$ (Whitehead, 1995). O acúmulo de nitrato depende também das condições climáticas que afetam o crescimento das plantas; assim, para uma mesma dose de adubação com nitrogênio, mais nitrato tende a ser estocado em períodos mais frios, secos ou de menor insolação, conclui o autor.

As fontes de $\mathrm{N}$ usadas em adubação de pastagem, quando o fertilizante é aplicado a lanço sobre as plantas e/ou solo, podem apresentar diferentes eficiências, pois 
resíduos vegetais sobre o solo, comuns em pastagens, apresentam alta atividade da ureáse, causando aumento na velocidade e intensidade das perdas e $\mathrm{NH}_{3}$ (Cantarella et al., 2002). Primavesi et al. (1999) observou perdas de $\mathrm{N}$ variando de 15 a mais de $40 \%$ do $\mathrm{N}$ aplicado na forma de uréia com dose de $200 \mathrm{~kg} \mathrm{ha}^{-1}$ de $\mathrm{N}$ em cinco adubações em pastagens de coastcross.

Alguns trabalhos foram realizados na tentativa de minimizar os efeitos da estacionalidade de produção através da utilização da adubação nitrogenada. Dias et al. (1998) estudando o uso de adubação nitrogenada no final do período de chuvas em três gramíneas tropicais, com doses variando de 0 a $400 \mathrm{~kg} \mathrm{~N} \mathrm{ha}^{-1}$ observaram aumento na produtividade, sendo que a dose de $100 \mathrm{~kg} \mathrm{~N} \mathrm{ha}^{-1}$ proporcionou maior eficiência de utilização e taxa de recuperação aparente do nitrogênio aplicado.

Segundo Corsi \& Nussio (1988) após a eliminação do meristema apical, pelo corte ou pastejo, a produção de forragem é determinada pela expansão das folhas, a qual dependente das condições climáticas e da disponibilidade de nitrogênio, justificando-se desse modo, a adubação com nitrogênio imediatamente após o corte.

Herling et al. (1991) observaram que a resposta das plantas forragerias ao nitrogênio apresenta interação com o potássio. Primavesi et al. (2001) observou que uma pastagem de coastcross adubada com $1000 \mathrm{~kg} \mathrm{ha}^{-1}$ de $\mathrm{N}$ extraiu quase $500 \mathrm{~kg} \mathrm{ha}^{-1}$ de $\mathrm{K}_{2} \mathrm{O}$ em 5 cortes durante a estação de crescimento.

A expressão do potencial genético da planta forrageira é dependente da atuação de componentes imponderáveis, juntamente com todo o sistema de produção adotado. Desta forma, é necessária a avaliação das relações entre os elementos bióticos e abióticos, em cada sistema, para melhor estabelecimento de bases de manejo que resltem em rendimentos agrícolas favoráveis. 


\subsection{Modelos matemáticos para previsão da produção em função de variáveis climáticas}

A estacionalidade de produção da forragem estimula o pecuarista a adotar técnicas para suprir a demanda por alimento nos períodos onde ocorrem déficits. A utilização de médias de produção de pastagem para estimativa da capacidade de suporte de um determinado pasto, torna as simulações para análises econômicas de sistema agropastoris limitada, existindo a necessidade no desenvolvimento mais apurado de equações básicas que permitam uma simulação mais próxima da realidade encontrada no campo (Tatizana, 1995), levando-se em consideração as condições climáticas: deficiências hídricas (Doorembos \& Kassan, 1979); temperatura do ar e fotoperíodo (Villa Nova et al.,1999) e adubação nitrogenada (Pinheiro et al., 2002).

Segundo Villa Nova et al. (1999) modelos matemáticos para estimativa do crescimento de gramíneas forrageiras apresentam desempenho aproximado das condições avaliadas em campo quando utiliza-se a unidade fototérmica (relação entre temperatura e fotoperíodo) para possibilitar a previsão de produtividade e o estabelecimento de critérios para otimizar a produção de sistemas de produção de forragem.

Pinheiro et al. (2002) utilizou um modelo matemático (função de Gompertz) para estimativa da produção de capim Tanzânia, calibrado em função do somatório de unidades fototérmicas e níveis de adubação nitrogenada em Piracicaba - SP, observndose que os dados simulados pelo modelo e os medidos em campo foram apresentaram boa correlação.

Porém, dentre os modelos existentes para previsão de produtividade em capim Elefante (Villa Nova et al., 1999) e capim Tanzânia (Pinheiro et al., 2002), foram considerados o potencial de produção da cultura irrigada sem deficiência hídrica. Desta

forma, o objetivo do presente trabalho de pesquisa foi avaliar o efeito do rendimento de capim Tanzânia conduzido sob os seguintes regimes hídricos: sem restrição, restrição de 25, 50 e 75\% da água disponível, avaliando a produção combinada com diferentes doses 
de adubações nitrogenadas durante 10 ciclos de corte, observando também o efeito de diferentes intensidades de temperatura e fotoperíodo. 


\section{MATERIAL E MÉTODOS}

\subsection{Local}

O experimento foi conduzido em área localizada na Escola Superior de

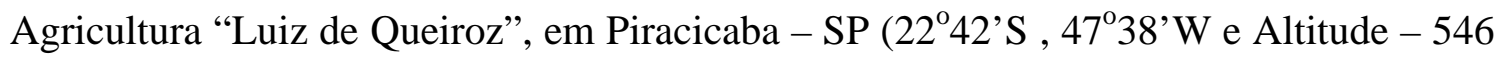
m), no período de maio de 2002 a novembro de 2003. O clima da região, segundo a classificação de Köppen, é do tipo Cwa (tropical úmido, apresentando três meses mais secos, junho, julho e agosto e chuvas durante o verão).

\section{1 Área Experimental}

Em fevereiro de 2002 foi realizada a sistematização do terreno por meio de um trator de esteira da área experimental com aproximadamente $500 \mathrm{~m}^{2}$. Foi utilizado uma retroescavadeira para realizar a perfuração de 4 trincheiras $(5,5 \times 5,0 \times 0,9 \mathrm{~m})$ no solo nos locais onde seriam instaladas os blocos.

As estufas que compreendiam o experimento foram construídas com as seguintes características: a) dimensões: 21,00 x 22,50 x 3,00 m; b) na cobertura da estufa utilizouse filme plástico polietileno de alta densidade de 150 micras, transparente, com tratamento anti-UV, instalado em peça única; c) A fixação do filme plástico foi realizada por perfis de alumínio e molas de aço galvanizado; d) O telado lateral de fechamento da estufa foi feito através de sombrite 30\% com tratamento anti-UV e e) A mureta perimetral foi construída com $45 \mathrm{~cm}$ de altura e largura de $6 \mathrm{~cm}$ em concreto. 
Foram utilizadas caixas d’água de 500 litros para plantio do capim com o objetivo de explorar maior número de tratamentos sem que houvesse a contaminação entre as lâmina de irrigação e doses de adubação nitrogenada, otimizando a superfície coberta das estufas.

Em abril de 2002 instalaram-se as 100 caixas d’água de cimento amianto com capacidade para 500 litros com as seguintes dimensões: 110,00 x 95,00 x 62,50 cm e peso de $66 \mathrm{~kg}$ cada. As caixas foram instaladas com a borda superior no nível do solo em 4 blocos de 25 caixas (Figura 1). No fundo das caixas colocou-se aproximadamente 50 litros de brita $\mathrm{n}^{0}$ 2, sobre uma camada de manta sintética (“bidin”) e um tubo de PVC de 35 mm para permitir acesso ao interior da caixa facilitando a drenagem (Figura 2).

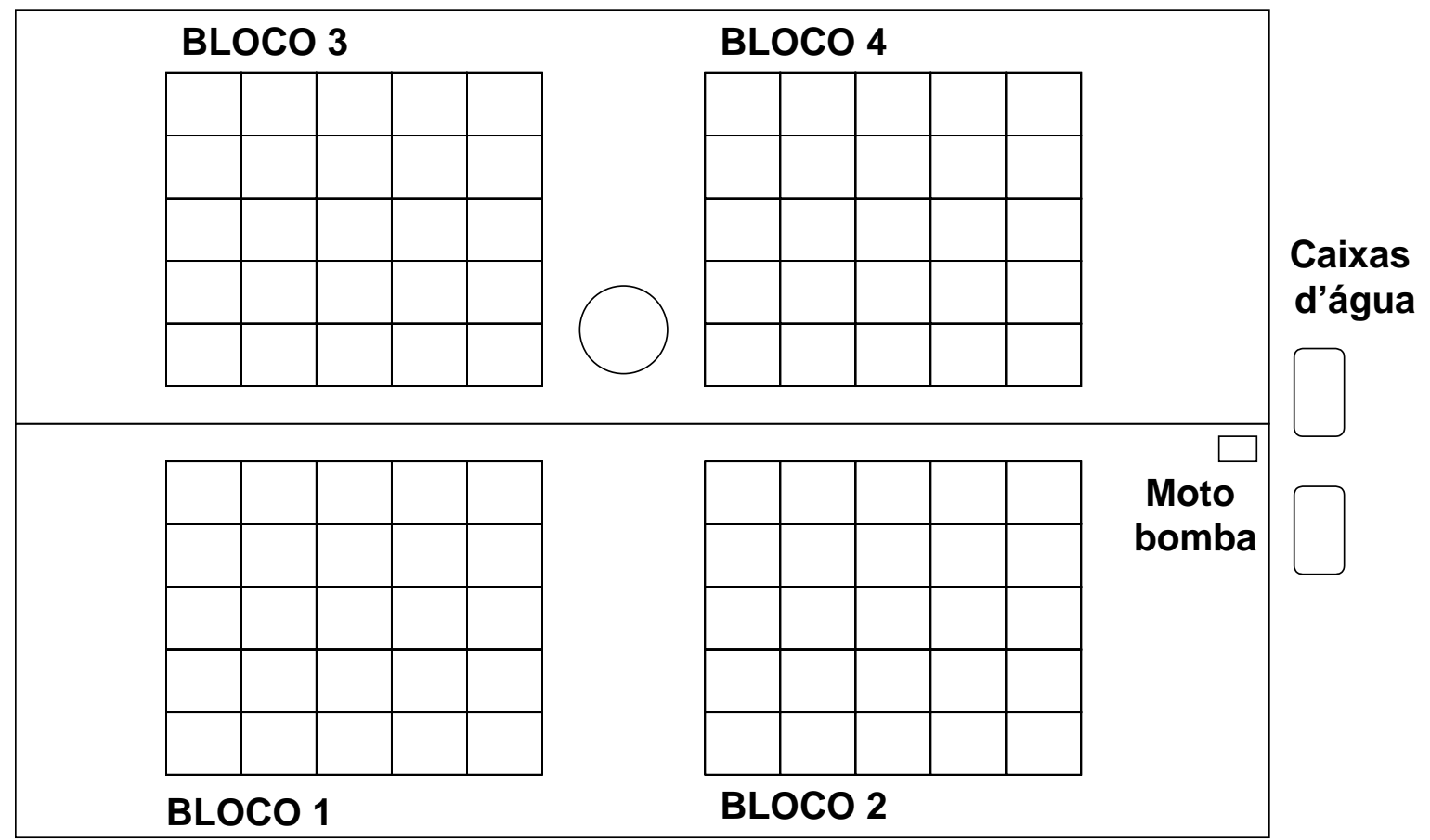

Figura 1 - Croqui da área experimental indicando a disposição dos blocos 


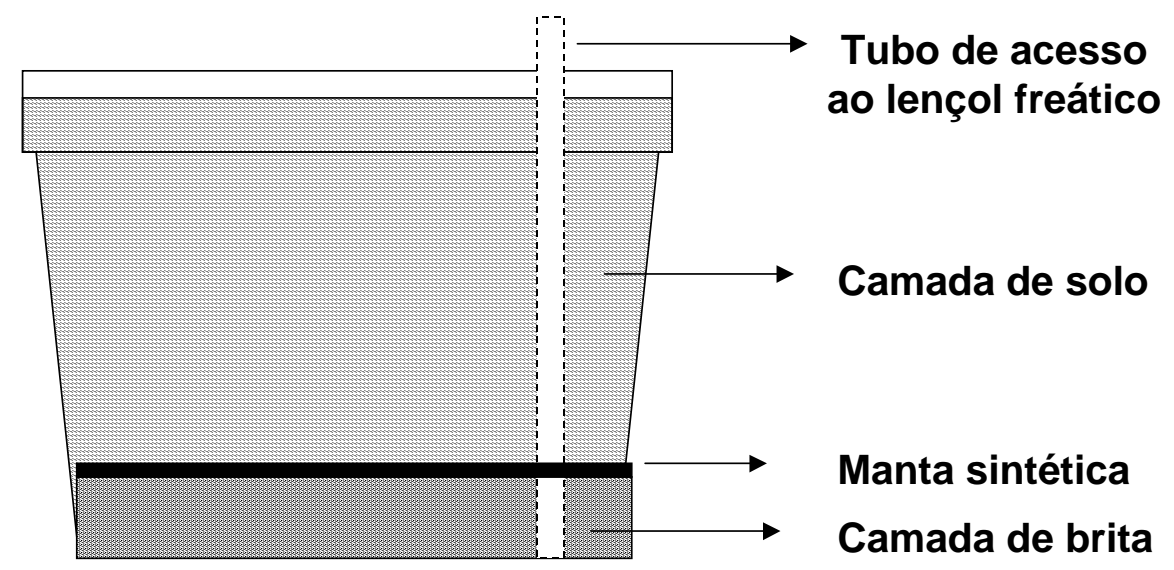

Figura 2 - Esquema de composição da caixa d’água de 500 l para os tratamento

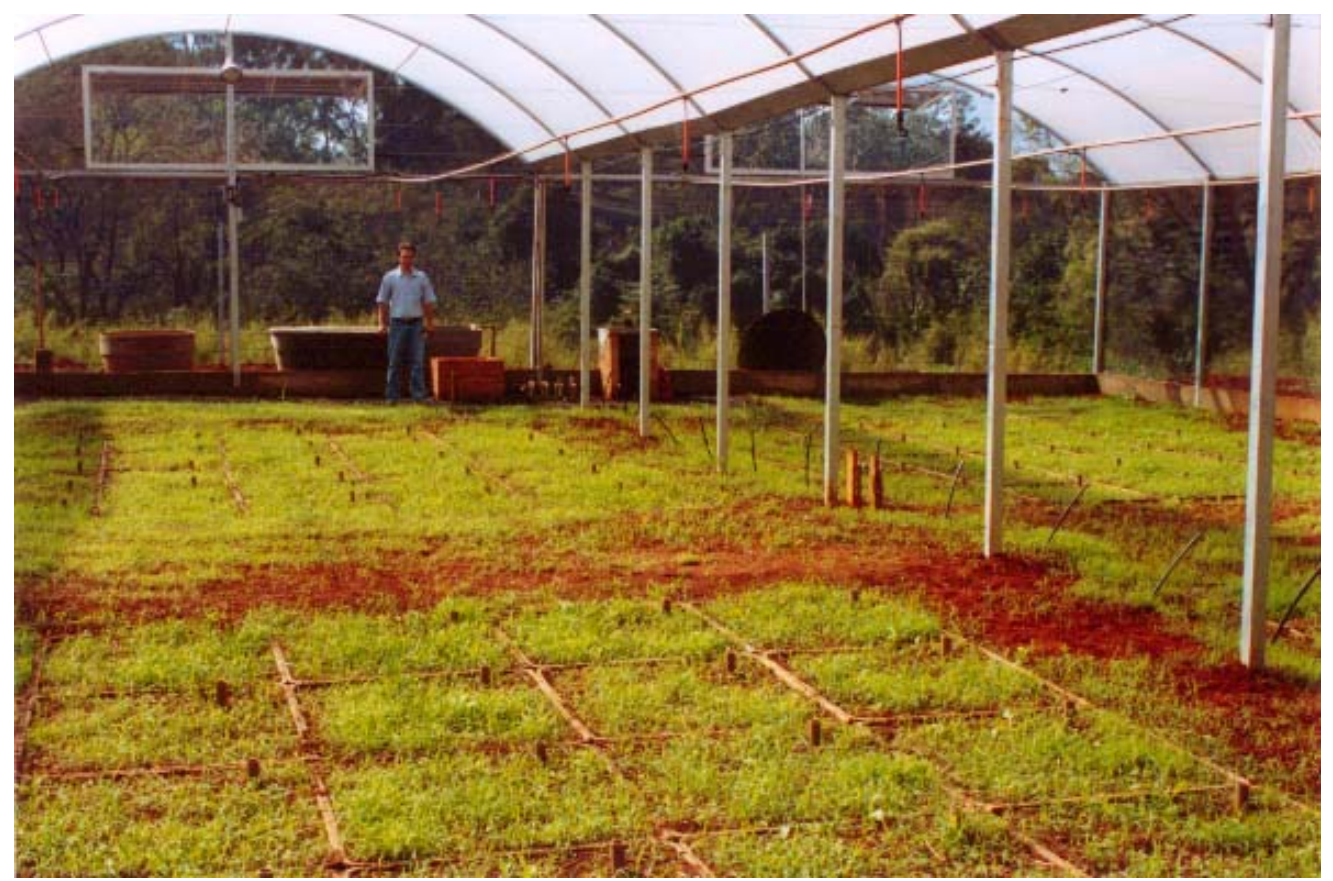

Figura 3 - Vista geral do experimento durante a fase de crescimento do capim Tanzânia 


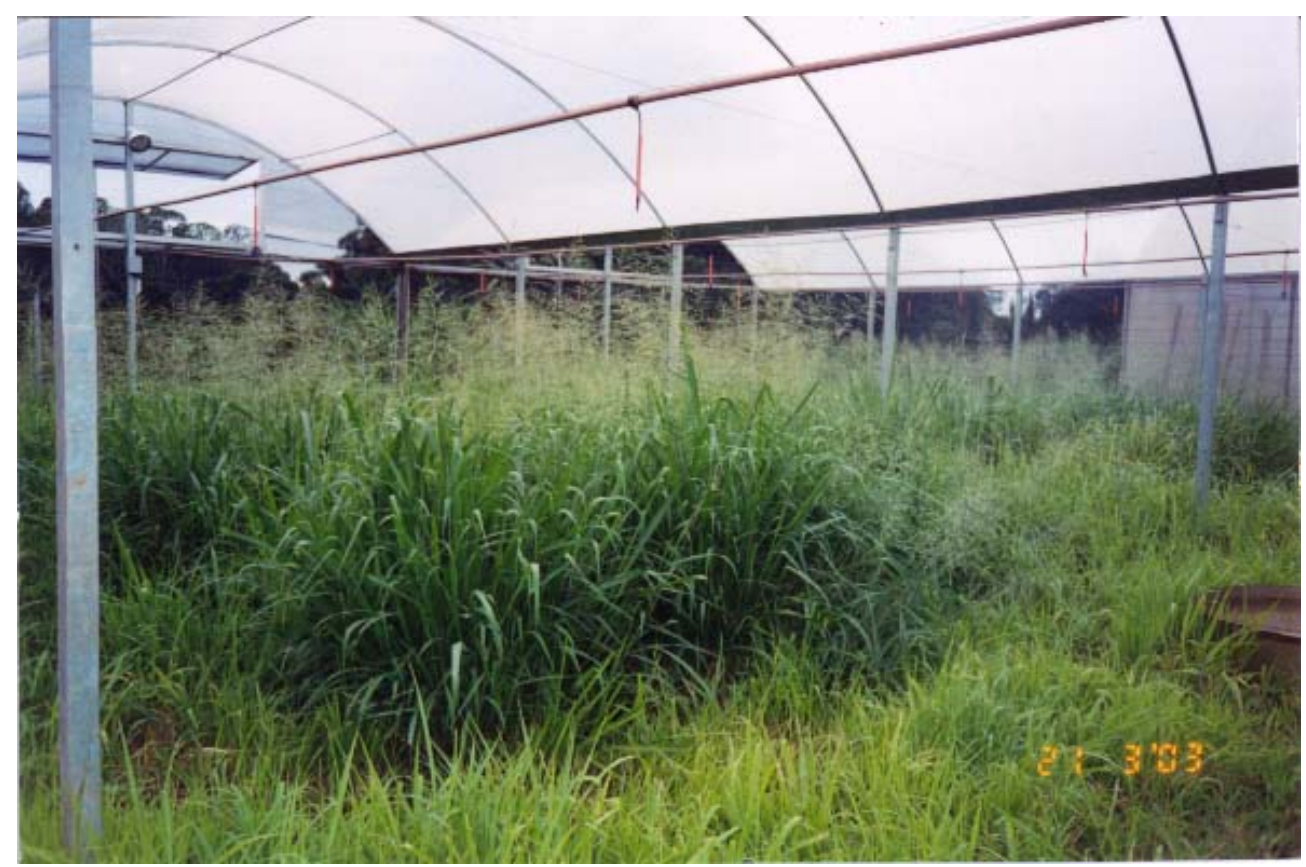

Figura 4 - Vista interna da área experimental durante o ciclo 3, com o capim Tanzânia emitindo sementes

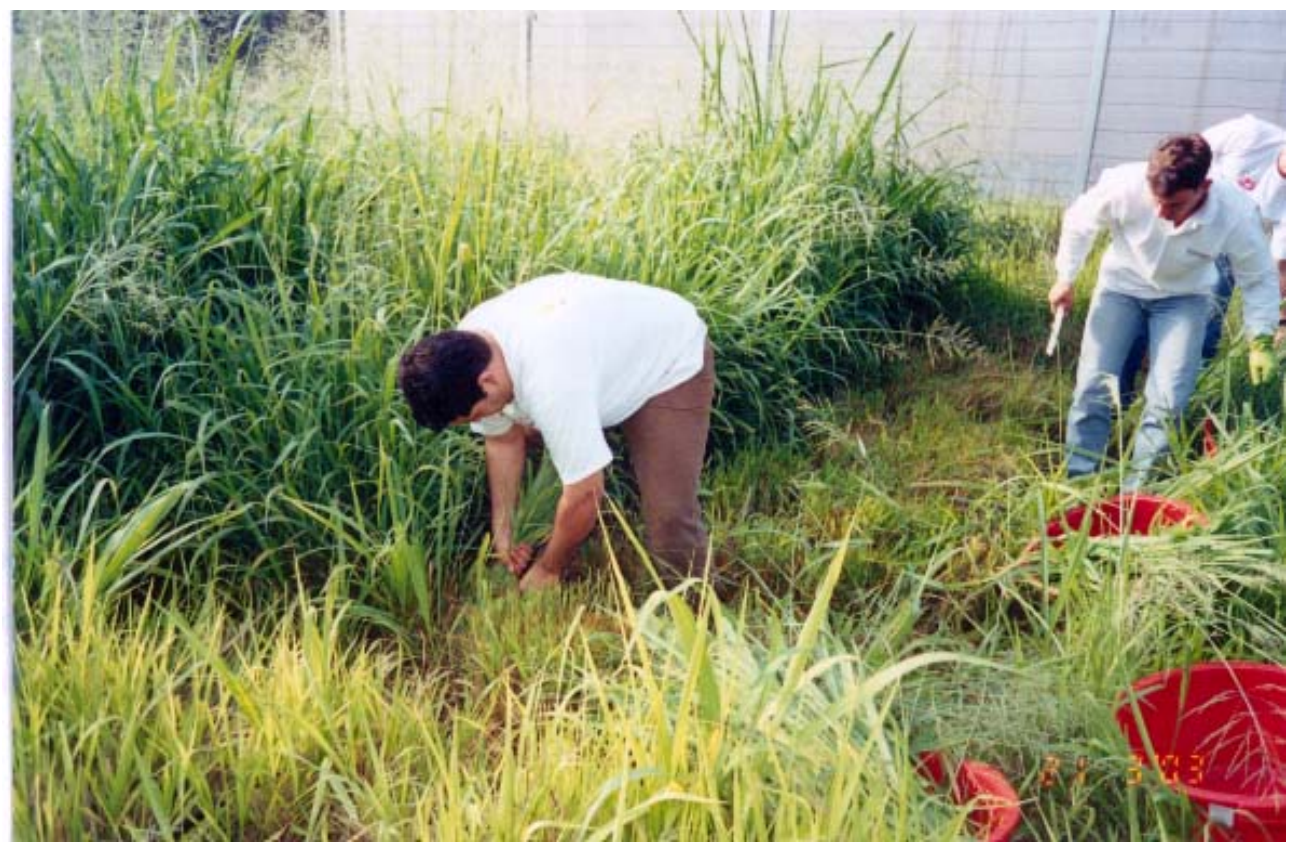

Figura 5 - Vista interna da área experimental durante o corte da forragem no ciclo 4 


\subsection{Análises de solo, adubação de correção e plantio do capim}

O solo da área experimental foi classificado como Latossolo Vermelho Amarelo Álico de textura média (Sertãozinho). Foram realizadas análises químicas (Tabela 1) e físicas (Tabela 2) na profundidade 0-0,40 m nos 4 blocos, para a determinação da necessidade de calagem e da adubação corretiva com fósforo, potássio e micronutriente.

Em função da análise de solo, a saturação por bases foi elevada a 80\% com a aplicação da dosagem de $3 \mathrm{t} \mathrm{ha}^{-1}$ de calcário dolomítico (PRNT de 120) (Corsi \& Nussio, 1988). Para correção da fertilidade do solo, foram aplicados $600 \mathrm{~kg} \mathrm{ha}^{-1}$ de $\mathrm{P}_{2} \mathrm{O}_{5}$ cuja fonte foi o superfosfato simples, $300 \mathrm{~kg} \mathrm{ha}^{-1}$ cuja fonte foi o cloreto de potássio (KCl) e, $30 \mathrm{~kg} \mathrm{ha}^{-1}$ de FTE BR 12 a fim de elevar os teores de micronutrientes (van RAIJ et. al., 1997; Cantarella et al., 2002).

A área foi preparada mecanicamente em maio de 2001 baseando-se em um revolvimento superficial do solo suficiente para o destorroamento do solo e incorporação dos produtos químicos aplicados. O capim Tanzânia foi semeado em área total através de sementes (Data: 16 de maio de 2001), com posterior vedação de 4 meses para possibilitar a formação da pastagem. 
Tabela 1. Análises químicas em amostras de solo na camada de $0-40 \mathrm{~cm}$ em latossolo vermelho amarelo, utilizado no preenchimento das caixas

\begin{tabular}{cccccccccccccc}
\hline Amostra & $\begin{array}{c}\mathrm{pH} \\
\mathrm{CaCl}_{2}\end{array}$ & $\begin{array}{c}\mathrm{M.O}^{1} \\
\mathrm{~g} \mathrm{dm}^{-3}\end{array}$ & $\begin{array}{c}\mathrm{P} \\
\mathrm{resina} \\
\mathrm{mg} \mathrm{dm}^{-3}\end{array}$ & & $\mathrm{~K}$ & $\mathrm{Ca}$ & $\mathrm{Mg}$ & $\mathrm{H}+\mathrm{Al}$ & $\mathrm{Al}$ & $\mathrm{S}_{\mathrm{B}}{ }^{2}$ & $\mathrm{CTC}^{3}$ & $\begin{array}{c}\mathrm{V} \\
\mathrm{mmol}_{\mathrm{c}} \mathrm{dm}^{-3}\end{array}$ & $\begin{array}{c}\mathrm{m} \\
\%^{5}\end{array}$ \\
\hline Bloco 1 & 4,4 & 10 & 5 & 1,3 & 9 & 6 & 25 & 2 & 16 & 41 & 39 & 11 \\
Bloco 2 & 4,7 & 13 & 8 & 2,5 & 13 & 7 & 20 & 1 & 23 & 43 & 53 & 4 \\
Bloco 3 & 4,7 & 13 & 6 & 2,3 & 11 & 7 & 22 & 1 & 20 & 42 & 48 & 5 \\
Bloco 4 & 4,8 & 13 & 6 & 2,7 & 13 & 8 & 22 & 1 & 24 & 46 & 52 & 4 \\
\hline
\end{tabular}

1'- Matéria orgânica

${ }^{2}$ - Soma de bases : $\mathrm{S}_{\mathrm{B}}=\mathrm{K}^{+}+\mathrm{Ca}^{2+}+\mathrm{Mg}^{2+}$

${ }^{3}$ - Capacidade de troca de cátions: $\mathrm{CTC}=\mathrm{S}_{\mathrm{B}}+\left(\mathrm{H}^{+}+\mathrm{Al}^{3+}\right)$

${ }^{4}$ - Porcentagem de saturação por bases: $\mathrm{V}=\left(100 \mathrm{~S}_{\mathrm{B}}\right) / \mathrm{CTC}$

${ }^{5}$ - Saturação por alumínio: $\mathrm{m}=\mathrm{Al}^{3+} /\left(\mathrm{Al}^{3+}+\mathrm{S}_{\mathrm{B}}\right) \cdot 100$

Tabela 2. Análise granulométrica em amostras de solo em latossolo vermelho amarelo, na profundidade 0-40 cm, utilizado no preenchimento das caixas

\begin{tabular}{cccccc}
\hline \multirow{2}{*}{ Amostra } & $\begin{array}{c}\text { Argila } \\
<0,002 \mathrm{~mm}\end{array}$ & $\begin{array}{c}\text { Silte } \\
0,053-0,002 \mathrm{~mm}\end{array}$ & Areia total & $\begin{array}{c}\text { Areia Grossa } \\
2,00-0,210 \mathrm{~mm}\end{array}$ & $\begin{array}{c}\text { Areia Fina } \\
0,210-0,053 \mathrm{~mm}\end{array}$ \\
\cline { 2 - 6 } & \multicolumn{5}{c}{$\mathrm{g} \mathrm{kg}^{-1}$} \\
\hline Bloco 1 & 184 & 41 & 775 & 268 & 507 \\
Bloco 2 & 190 & 13 & 797 & 260 & 537 \\
Bloco 3 & 192 & 43 & 765 & 259 & 506 \\
Bloco 4 & 190 & 40 & 770 & 279 & 491 \\
\hline
\end{tabular}




\subsection{Tratamentos e delineamento experimental}

Foram estudados a relação fatorial entre 5 doses de adubação e 5 lâminas de irrigação. As doses de nitrogênio 0, 30, 60, 110 e 270 kg N.(ha.ciclo) ${ }^{-1}$ foram aplicados após o corte, nas parcelas, via fertirrigação com nitrato de potássio e nitrato de amônia. O potássio foi aplicado na forma de nitrato de potássio, junto com os tratamento de $\mathrm{N}$, a fim de repor o $\mathrm{K}_{2} \mathrm{O}$ removido pelos cortes e para manter os níveis de $\mathrm{K}$ na matéria seca (MS) em um mínimo de 20 g. $\mathrm{kg}^{-1}$ (PRIMAVESI et al, 2001).

O delineamento experimental utilizado foi em blocos casualizados, com quatro repetições (Figura 6). Nos blocos, foram distribuídas aleatoriamente as diferentes lâminas de irrigação $\mathrm{L}_{25}, \mathrm{~L}_{50}, \mathrm{~L}_{75}, \mathrm{~L}_{100}$ e $\mathrm{L}_{125} \%$ da $\mathrm{ET}_{\text {Testemunha }}$ e doses de nitrogênio $\mathrm{D}_{0}$, $\mathrm{D}_{30}, \mathrm{D}_{60}, \mathrm{D}_{110}$ e $\mathrm{D}_{270} \mathrm{~kg} \mathrm{~N}^{-1}$ ciclo $^{-1}$, totalizando-se 25 tratamentos.
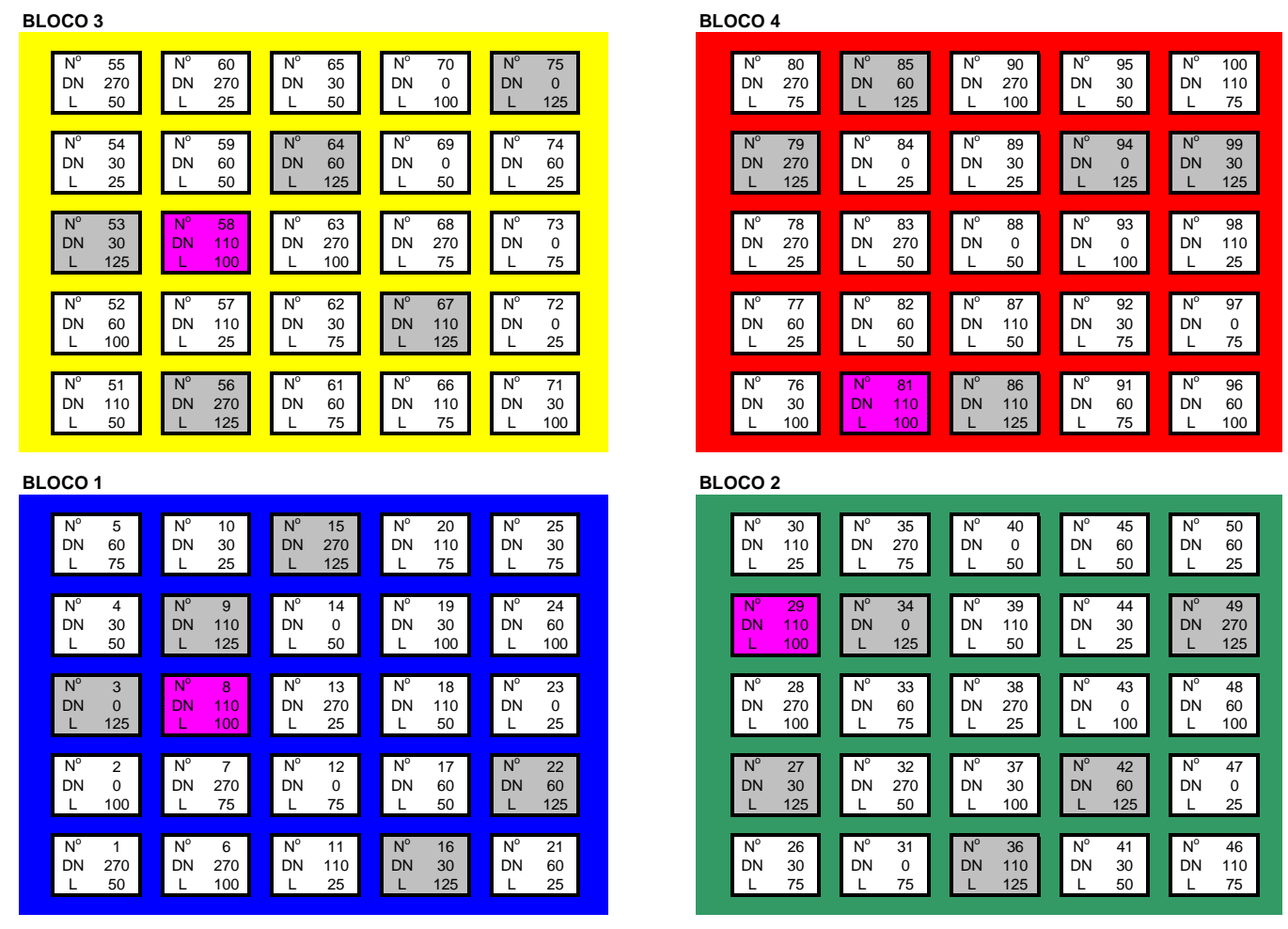

Figura 6 - Número ordinário dos tratamentos $\left(\mathrm{N}^{0}\right)$ em função dos tratamentos de adubação nitrogenada (DN) e lâmina de irrigação (L) 


\subsection{Sistema e condução da irrigação}

A variação da lâmina de irrigação, representando os tratamento de déficit hídrico, foram obtidos a partir de um percentual da quantidade de água evapotranspirada pela testemunha com 100\% de reposição, mantida à capacidade de campo, através do monitoramento do potencial mátrico do solo com base em tensiômetros de punção digital, instalados com o objetivo de monitorar o perfil do solo, nas profundidades de 0,10, 0,30 e 0,50 m, com leituras realizadas diariamente durante o período de amostragem.

Como a quantidade de água a ser aplicada nos tratamentos deveria ter boa precisão, para respeitar a disposição de blocos, as irrigações foram realizadas com o mesmo tempo, sendo utilizado o sistema de irrigação tipo gotejamento, com os emissores autocompensantes com vazão de 2,4 litros hora $^{-1}$, que permitiu realizar a equalização dos tratamentos que foram porções de $25 \%\left(\mathrm{~L}_{25}\right), 50 \%\left(\mathrm{~L}_{50}\right), 75 \%\left(\mathrm{~L}_{75}\right)$, 100\% (100\% testemunha $\left.\mathrm{L}_{100}\right)$ e 125\% ( $\left.\mathrm{L}_{125}\right)$, totalizando-se 5 lâminas de irrigação. A variação da vazão foi realizada através do número de gotejadores em cada tratamento, distribuídos proporcionalmente sobre as caixas d'água de acordo com o tratamento, ou seja: $\mathrm{L}_{25} 1$ gotejador, $\mathrm{L}_{50} 2$ gotejadores, $\mathrm{L}_{75} 3$ gotejadores, $\mathrm{L}_{100} 4$ gotejadores e $\mathrm{L}_{125} 5$ gotejadores.

A freqüência de irrigação e a quantidade de água aplicada foram determinadas em função da variação do potencial mátrico no tratamento testemunha $\left(\mathrm{L}_{100}\right)$. A irrigação teve início quando a média dos tensiômetros, posicionados a $20 \mathrm{~cm}$, registravam entre 0,03 e -0,04 MPa.

Os tensiômetros foram instalados no tratamento $\mathrm{L}_{100}$ e $\mathrm{D}_{110}$ com repetição nos 4

blocos e, devido as condições financeiras não foi possível monitorar e diferenciar a lâmina de irrigação entre os tratamento de adubação, sendo necessário maior número de sensores e, um sistema de irrigação capaz de diferir a água aplicada em cada um dos tratamentos dos blocos. 


\subsection{Amostragem da forragem}

O corte da forragem foi conduzido de forma manual, com altura de corte de 0,30 a 0,40 proporcionando um resíduo de 3500 a $5000 \mathrm{~kg}$ de matéria verde $\mathrm{ha}^{-1}$, em intervalos de 35 dias, conforme a recomendação de GARCIA (1993). Visando minimizar o coeficiente de variação e a eficiência do processo de amostragem, foram utilizadas caixas d’água com superfície de aproximadamente $1 \mathrm{~m}^{2}$, estimando-se a massa de forragem através do método destrutivo (PENATI, et al. 2001).

Após o corte, a forragem foi pesada em balança digital (precisão: 0,05 kg) e denominada matéria verde total (MVT), em seguida foram retiradas sub-amostras representativas da massa (aproximadamente 0,20 kg de material verde), as quais foram identificadas e pesadas novamente com balança digital (precisão: 0,001 kg) e colocadas em sacos de papel, denominando-se matéria verde parcial (MVP). O procedimento de secagem da forragem foi realizado em estufa com circulação forçada de ar a $65{ }^{\circ} \mathrm{C}$, até peso seco constante durante 24 a 48 h e posteriormente pesada.

\subsection{Produção de forragem}

Para cálculo da produção total de matéria verde por hectare, foram utilizadas as Equção 1, 2 e 3.

$$
\begin{aligned}
& M S=\frac{M S P-T_{\text {final }}}{M V P-T_{\text {inicial }}} \\
& M S T=\left(M V T-T_{\text {bacia }}\right) \cdot M S
\end{aligned}
$$




$$
P M S=\frac{M S T .100}{A_{c x}}
$$

Onde:

$M S$ - Relação entre matéria seca e matéria verde (g.g $\left.{ }^{-1}\right)$;

MSP - Matéria seca parcial (g);

MVP - Matéria verde parcial (g);

$T_{\text {inicial }}$ - Tara do saco de papel antes do secamento (g);

$T_{\text {final }}$ - Tara do saco de papel após o secamento (g);

MST - Produção total de matéria seca na área experimental (g);

MVT - Produção total de matéria verde na área experimental (g);

$T_{\text {bacia }}$ - Tara da bacia para coleta do capim (g);

PMS - Produção de matéria seca por hectare (t.ha $\left.{ }^{-1}\right)$;

$\mathrm{A}_{\mathrm{cx}}$ - Área superficial do tratamento $\left(\mathrm{m}^{2}\right)$.

\subsection{Eficiência do uso da água (EUA)}

A eficiência do uso da água foi determinada pela divisão da massa seca, produzida em um período de crescimento, pela quantidade de água aplicada durante esse mesmo período, seguindo orientação de Pieterse et al. (1997). O denominador da Equação 4 representa a lâmina total de água aplicada em cada período de crescimento (Soria, 2002).

$$
E U A=\frac{Y}{T}
$$

Onde:

EUA - eficiência do uso da água ( $\left.\mathrm{kg} \mathrm{MS} \mathrm{mm}^{-1} \mathrm{ha}^{-1}\right)$; 
Y - produção de matéria seca $\left(\mathrm{kg} \mathrm{ha}^{-1}\right)$;

$\mathrm{T}$ - água para o crescimento (mm).

\subsection{Fator de resposta da cultura}

O coeficiente de resposta a água foi determinado pela Equação 5.

$$
\left(1-\frac{Y r}{Y m}\right)=k y\left(1-\frac{E T r}{E T m}\right)
$$

Onde:

- $\quad Y r$ - rendimento real obtido;

- $\quad Y m$ - rendimento máximo obtido;

- $k y$ - coeficiente de resposta da cultura;

- $E T r$ - evapotranspiração real

- ETm - evapotranspiração máxima.

\subsection{Análise estatística}

A análise de variância de Fisher (Gomes, 1987) para as variáveis estudadas foi executada utilizando-se o programa SAS e, no caso de rejeição da hipótese de nulidade, foi utilizado o programa Table Curve para obtenção das superfícies de resposta, cuja avaliação teve como critétrio o valor F, o coeficiente de correlação. 


\section{RESULTADOS E DISCUSSÃO}

\subsection{Dados meteorológicos}

No início do experimento (30/10/2002) foi realizado um corte no capim Tanzânia para uniformização da área experimental através de roçadeira motorizada e a adubação do capim com as dosagens de adubação pré-determinadas. Os cortes foram realizados a intervalos de 35 dias, respeitando o ciclo do capim. Nos ciclos 1 e 3, o período de crescimento foi de 37 e 36 dias respectivamente, devido a problemas técnicos ocorridos nos equipamentos utilizados. Foram realizados 10 cortes no capim, encerrando-se o experimento após 353 dias de coletas de dados (18/10/2003).

Os valores de temperatura foram obtidos dentro da área experimental e os valores de precipitação através da estação meteorológica padrão do Departamento de Física e Meteorologia Ambiental da ESALQ/USP (Tabela 3). A temperatura média durante o período de crescimento foi de $21.4{ }^{\circ} \mathrm{C}$. A temperatura média dos ciclos 1 a 4 foi

próxima de $24{ }^{\circ} \mathrm{C}$ e no ciclo 4 , foi observado a maior temperatura $\left(24.4{ }^{\circ} \mathrm{C}\right.$ ). Enquanto que os ciclos 6 a 9 a temperatura ficou próxima de $18.8{ }^{\circ} \mathrm{C}$. As temperaturas médias dos ciclos ficaram próximas da normal climatológica (Figura 7), com exceção do ciclo 9, onde foi constatado a menor temperatura $18.0^{\circ} \mathrm{C}$, que normalmente seria em torno de 21 ${ }^{\mathrm{o}} \mathrm{C}$.

O saldo hídrico foi positivo nos ciclos 1, 3 e 4 quando comparado a chuva efetiva com a irrigação do tratamento $\mathrm{L}_{100}$ (Figura 8), ou seja, em experimento conduzido a campo neste período, não seria necessária acionar o equipamento de irrigação, da mesma forma que não seria possível conduzir o capim Tanzânia sob déficit hídrico neste 
período sem a utilização da estufa. Soria, (2002), não observou diferença significativa na produção de forragem em capim Tanzânia conduzidos com lâmina sob déficit em experimento conduzido a campo, devido à interação existente entre o efeito climático (precipitação excessivamente maior que a evapotranspiração), elevada capacidade de armazenamento de água pelo solo e desenvolvimento radicular das plantas em profundidade.

Tabela 3 - Período de crescimento do capim Tanzânia, temperatura média, chuva efetiva, irrigação $\left(\mathrm{L}_{100}\right)$ e saldo hídrico

\begin{tabular}{|c|c|c|c|c|c|c|c|c|}
\hline \multirow[t]{2}{*}{ Ciclo } & \multicolumn{3}{|c|}{ Período de crescimento } & \multirow{2}{*}{$\begin{array}{l}\text { Temp } \\
\text { Média } \\
{ }^{\circ} \mathrm{C}\end{array}$} & \multirow{2}{*}{$\begin{array}{c}\text { Rad. } \\
\text { Solar }^{1} \\
\text { MJ m }^{-2} \cdot \mathrm{d}^{-1}\end{array}$} & \multirow{2}{*}{$\begin{array}{c}\text { Chuva } \\
\text { efetiva } \\
\text { mm }\end{array}$} & \multirow{2}{*}{$\begin{array}{c}\text { Irrigação }^{2} \\
\mathrm{~mm}\end{array}$} & \multirow{2}{*}{$\begin{array}{c}\text { Saldo } \\
\text { Hídrico }^{3} \\
\text { mm }\end{array}$} \\
\hline & Início & Final & Dias & & & & & \\
\hline 1 & $30 / 10 / 02$ & $06 / 12 / 02$ & 37 & 23.8 & 373.2 & 228.6 & 185 & 43.6 \\
\hline 2 & 07/12/02 & 10/01/03 & 35 & 24.3 & 368.8 & 158.8 & 168 & -9.2 \\
\hline 3 & $11 / 01 / 03$ & $15 / 02 / 03$ & 36 & 24.0 & 322.8 & 273.1 & 136 & 157.1 \\
\hline 4 & $16 / 02 / 03$ & $22 / 03 / 03$ & 35 & 24.4 & 328.6 & 175.2 & 145 & 30.2 \\
\hline 5 & 23/03/03 & $26 / 04 / 03$ & 35 & 21.7 & 261.3 & 82.1 & 92 & -9.9 \\
\hline 6 & $27 / 04 / 03$ & $31 / 05 / 03$ & 35 & 18.7 & 185.0 & 54.1 & 73 & -18.9 \\
\hline 7 & 01/06/03 & 05/07/03 & 35 & 18.8 & 171.3 & 9.1 & 60 & -50.9 \\
\hline 8 & 06/07/03 & 09/08/03 & 35 & 18.8 & 164.5 & 24.6 & 105 & -80.4 \\
\hline 9 & $10 / 08 / 03$ & $13 / 09 / 03$ & 35 & 18.0 & 220.0 & 15.4 & 97 & -109.6 \\
\hline 10 & $14 / 09 / 03$ & 18/10/03 & 35 & 21.2 & 279.3 & 35 & 127 & -92.0 \\
\hline Total & & & 353 & - & & 1.056 & 1.196 & \\
\hline
\end{tabular}

\footnotetext{
${ }^{1}$ - Radiação solar líquida

2 - Irrigação na parcela testemunha $\left(\mathrm{L}_{100}\right)$ controlada por tensiômetros

3 - Saldo hídrico = Chuva efetiva - Irrigação
} 


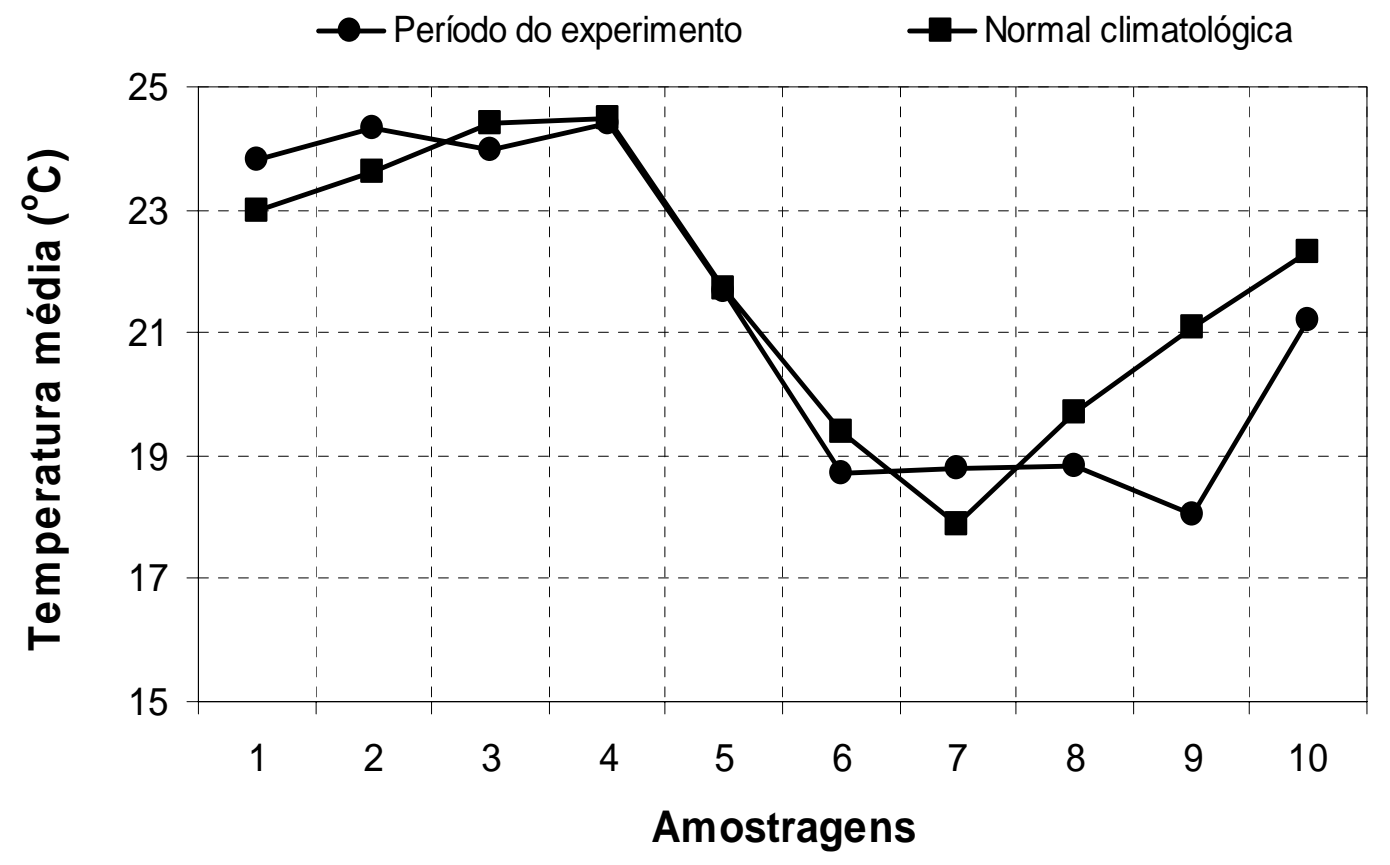

Figura 7 - Comparação da variação de temperatura média ao longo do período experimental e a temperatura média da normal climatológica

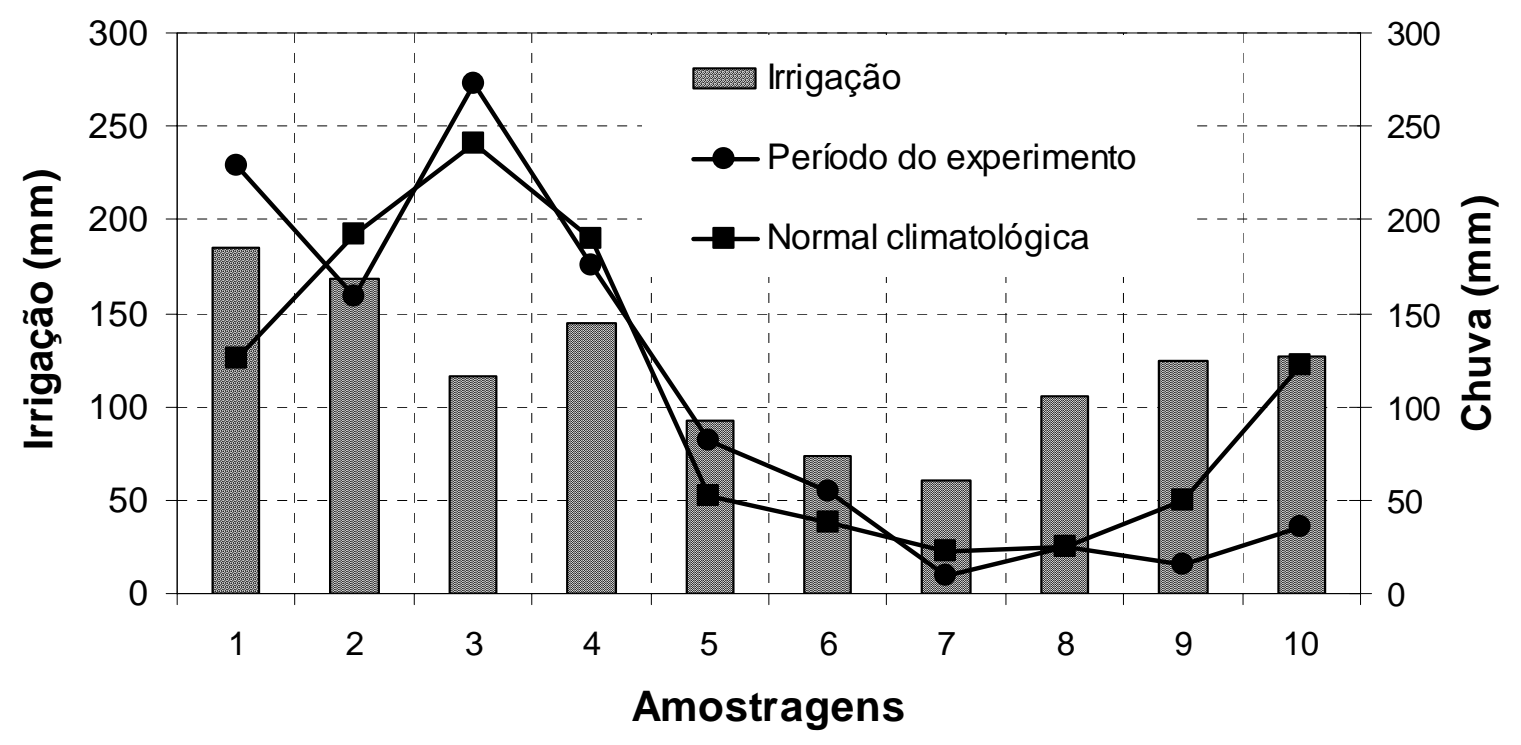

Figura 8 - Comparação da variação de precipitação total ao longo do período experimental, a precipitação total da normal climatológica e a irrigação aplicada no tratamento de referência $\left(\mathrm{L}_{100 \%}\right)$ 


\subsection{Lâmina de irrigação do capim Tanzânia}

A influência das condições climáticas e do tipo de rebrota sobre o desenvolvimento e produção do capim Tanzânia é constatada através da lâmina de irrigação aplicada durante o período de amostragem (Tabela 4). A lâmina requerida pelo capim submetido ao tratamento $\mathrm{L}_{100}$ foi variável em função da necessidade de água da planta, identificada através dos tensiômetros. A lâmina total aplicada durante os 10 ciclos de pastejo foi de 1485, 1188, 891, 594 e 297 mm para os tratamentos $\mathrm{L}_{25}$, $\mathrm{L}_{50}$, $\mathrm{L}_{75}$, $\mathrm{L}_{100}$ e $\mathrm{L}_{125 \%}$ respectivamente.

Tabela 4. Lâmina de irrigação aplicada nos ciclos do capim Tanzânia em função dos tratamentos

\begin{tabular}{cccccc}
\hline Ciclo & \multicolumn{5}{c}{ Tratamento } \\
& $\mathrm{L}_{125}$ & $\mathrm{~L}_{100}$ & $\mathrm{~L}_{75}$ & $\mathrm{~L}_{50}$ & $\mathrm{~L}_{25}$ \\
\hline 1 & & \multicolumn{3}{c}{ Irrigação $(\mathrm{mm})$} \\
2 & 231 & 185 & 139 & 93 & 46 \\
3 & 210 & 168 & 126 & 84 & 42 \\
4 & 170 & 136 & 102 & 68 & 34 \\
5 & 181 & 145 & 109 & 73 & 36 \\
6 & 115 & 92 & 69 & 46 & 23 \\
7 & 91 & 73 & 55 & 37 & 18 \\
8 & 75 & 60 & 45 & 30 & 15 \\
9 & 131 & 105 & 79 & 53 & 26 \\
10 & 121 & 97 & 73 & 49 & 24 \\
Total & 159 & 127 & 95 & 64 & 32 \\
\hline
\end{tabular}


Pinheiro et al. (2002) usou um método para estimativa da produtividade do capim Tanzânia através de um modelo matemático (função de Gompertz), calibrado em função da somatória de unidades fototérmicas. A correlação do modelo entre fotoperíodo e temperatura, apresentou correlação significativa com a produção, chegando à máxima produção de $4.500 \mathrm{~kg} \mathrm{MS} \mathrm{ha}^{-1}$, no mês de fevereiro, após o período de 36 dias de descanso, e a produção mínima de $290 \mathrm{~kg} \mathrm{MS} \mathrm{ha}^{-1}$, no mês de julho.

A necessidade de água no ciclo 1 foi de $185 \mathrm{~mm}$, diminuindo até o ciclo 7 (60 $\mathrm{mm}$ ), voltando a subir até $127 \mathrm{~mm}$ (ciclo 10), acompanhado a tendência da temperatura média, ou seja, existe uma correlação entre consumo de água e temperatura média do ar (Figura 9), quanto maior a disponibilidade de radiação solar, maior a temperatura média, aumentando o potencial de evapotranspiração do sistema solo-planta-atmosfera.

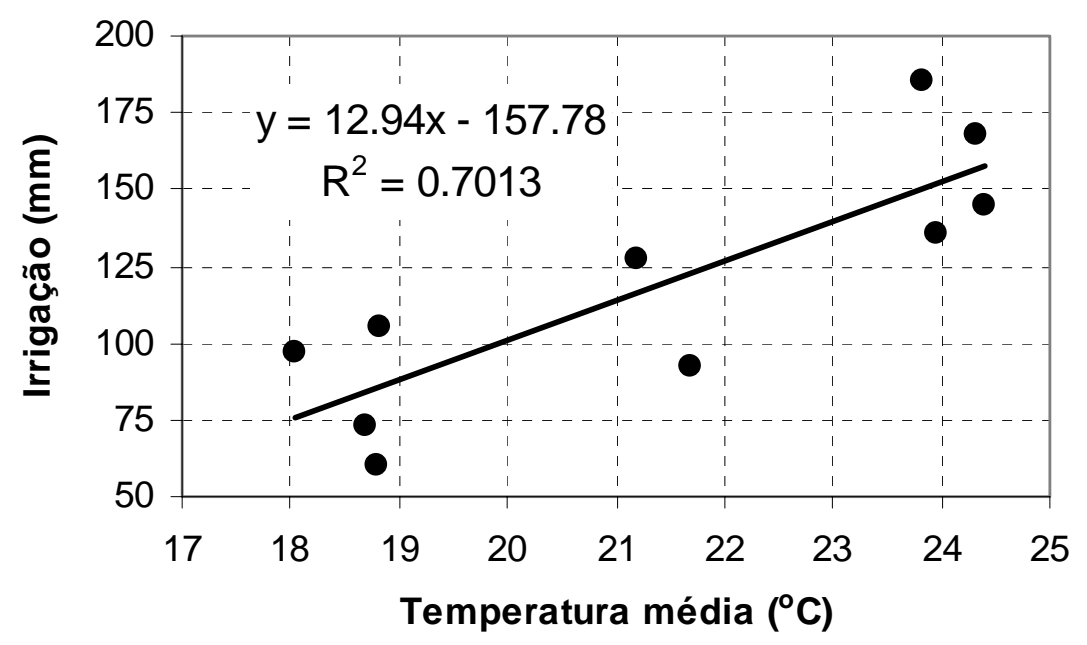

Figura 9 - Correlação entre a necessidade de irrigações do capim Tanzânia no tratamento $\mathrm{L}_{100}$ e a temperatura média do ciclo

Como pode ser observado na Figura 10 o potencial de água no período de crescimento ficou em média próximo a - 0,04 MPa, variando em função da evapotranspiração da cultura e o restabelecimento da umidade do solo através das 
irrigações. O déficit de água afeta o crescimento da planta provocando alterações em sua anatomia, morfologia e bioquímica (Kramer, 1969).

Segundo Reichardt (1987), a manutenção do potencial matricial do solo entre os limites de -0,02 e -0,2 MPa na profundidade radicular de 15 a $150 \mathrm{~cm}$ parece ser ideal para a produção vegetativa. Potenciais maiores ou próximos de $-0,02 \mathrm{MPa}$ não permitem boa aeração, favorecem o desenvolvimento de patógenos anaeróbicos e potenciais menores que $-0,2 \mathrm{MPa}$ podem reduzir a produtividade. No período destinado a produção de sementes, o solo deve ser mantido mais seco, com manutenção do potencial matricial entre os limites de -0,2 a -0,8 MPa.

Cunha (1991), em condições de campo, constatou maior produção da alfafa cv, Crioula quando a irrigação foi manejada no período primavera-verão, com potencial de água no solo superior a -0,06 MPa, enquanto Cossa e Pedras (1997), estudando em casa de vegetação a produção cv. Crioula em três regimes hídricos (-0,004 - capacidade de campo, -0,004 a -0,001 MPa e -0,04 a -0,4 MPa), constataram queda na produtividade da parte aérea e das raízes com o potencial matricial no solo entre -0,004 e -0,04 MPa.Entretanto, Tashima (1995), também em casa de vegetação, estudando níveis de água no solo para a cultura da alfafa, correspondendo a -0,001 (capacidade de campo); 0,05 e 1,5 MPa, conclui que maiores potenciais de água no solo permitiram melhor desenvolvimento vegetativo e produtividade até o quinto corte e da altura até o sexto corte; a partir de então, o processo inverteu-se, possivelmente devido à redução na aeração do solo, ocasionada pelo aumento no volume de raízes, em conseqüência do volume limitado de solo. 


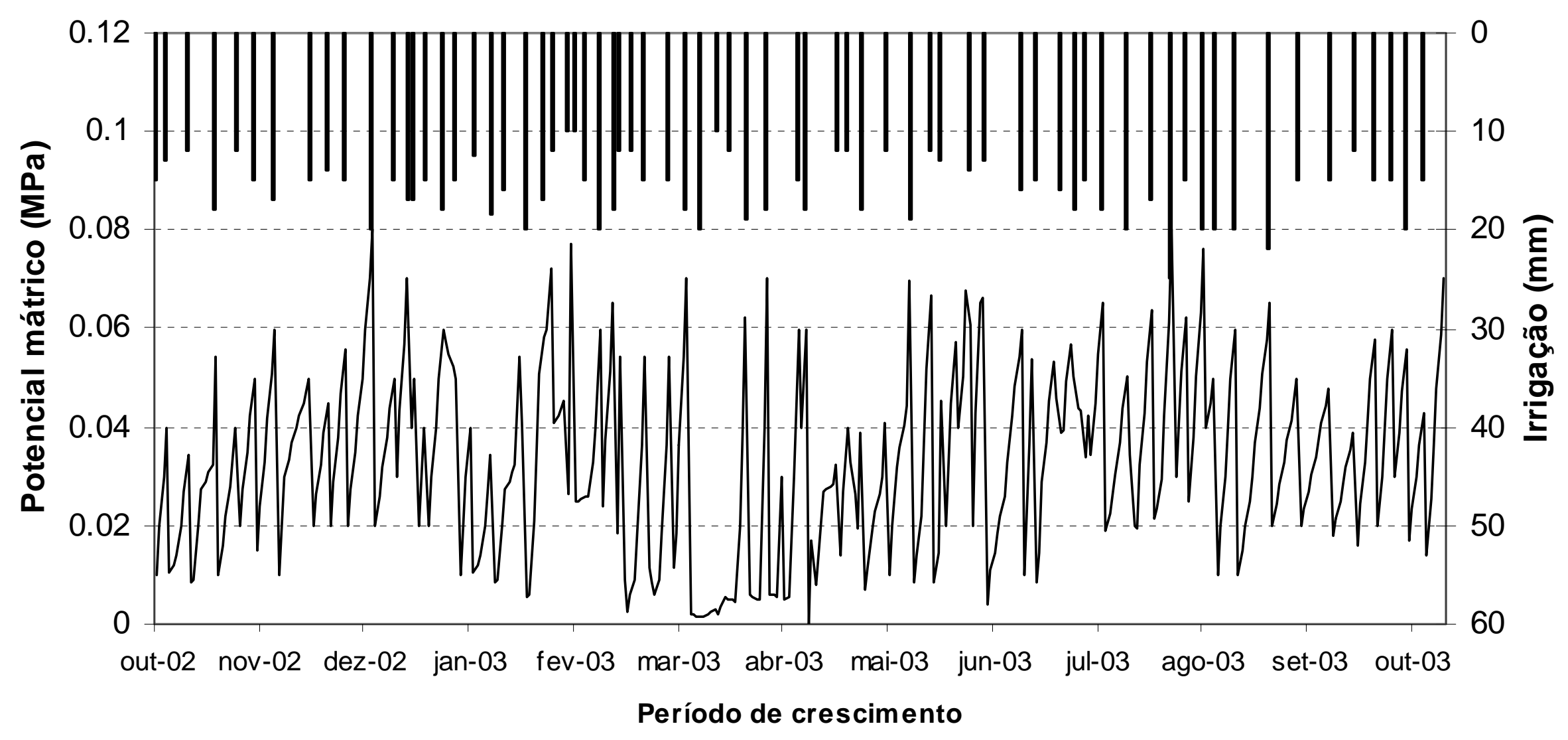

Figura 10 - Potencial mátrico do solo cultivado por capim Tanzânia, monitorado através de tensiômetros instalados a profundidade de 0,20 m para o período de crescimento de 30/10/02 a 18/10/03 


\subsection{Efeito da irrigação na produção de forragem}

A produção total do capim Tanzânia sob o tratamento $\mathrm{D}_{0}$ não apresentou diferença significativa em função das lâminas $\mathrm{L}_{75}, \mathrm{~L}_{100}$ e $\mathrm{L}_{125}$ (Figura 11). Porém quanto maior a dose de adubação nitrogenada, mais significativo é o efeito da deficiência hídrica na produção de forragem do capim Tanzânia (Figuras 12, 13, 14 e 15). Desta forma, quanto mais intensificado for o sistema de produção, maior será a quebra de produtividade quando ocorrer veranicos na produtividade, sendo um atrativo importante ao pecuarista optar por um sistema de irrigação, evitando-se os riscos climáticos, para garantir a produção. 


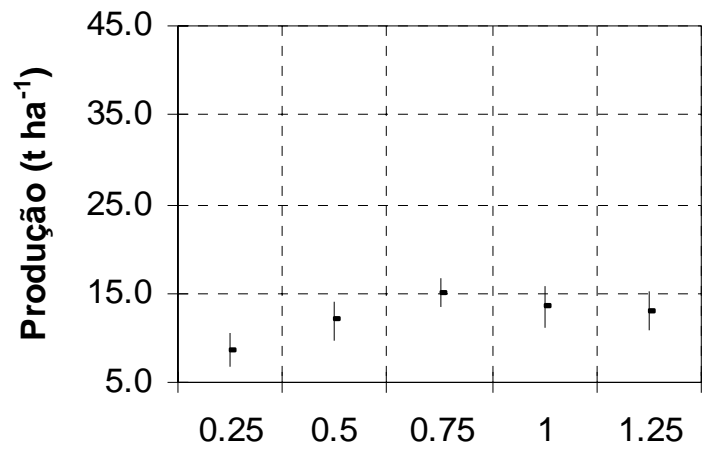

Figura 11 - Produção de forragem para o tratamento $0 \mathrm{~kg} \mathrm{~N}$ ciclo $^{-1}$ em função da lâmina de irrigação

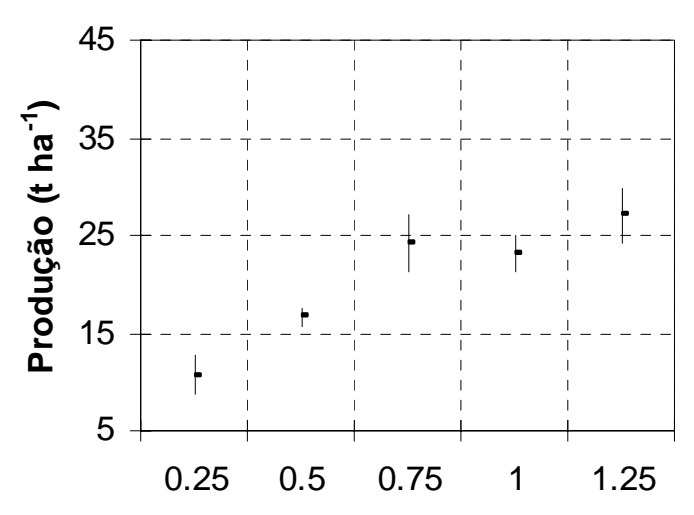

Figura 13 - Produção de forragem para o tratamento $60 \mathrm{~kg} \mathrm{~N}$ ciclo $^{-1}$ em função da lâmina de irrigação

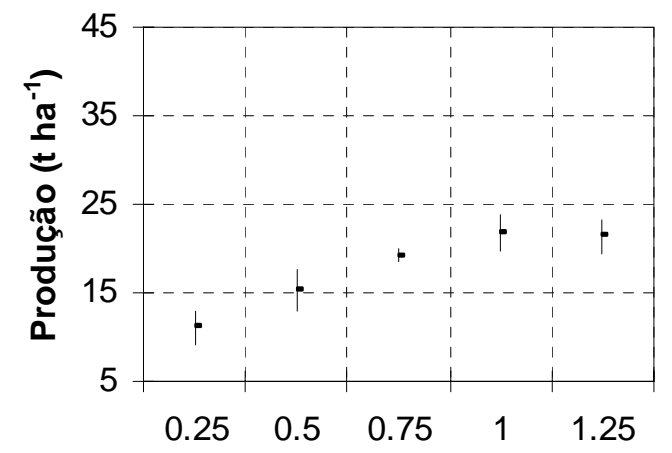

Figura 12 - Produção de forragem para o tratamento $30 \mathrm{~kg} \mathrm{~N}$ ciclo $^{-1}$ em função da lâmina de irrigação

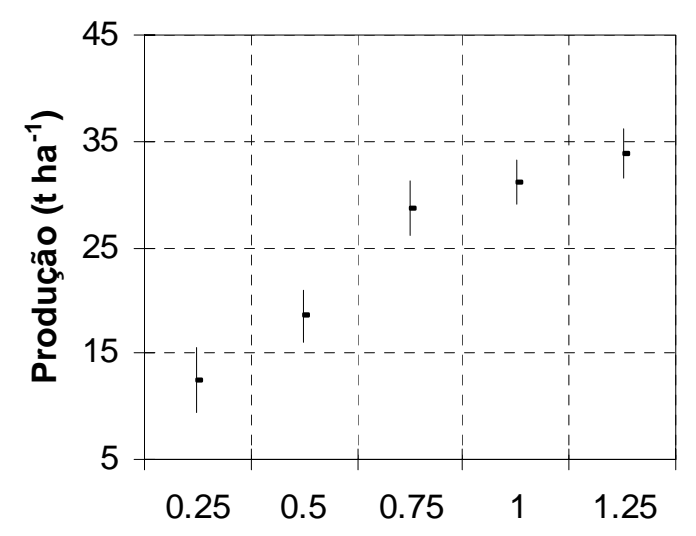

Figura 14 - Produção de forragem para o tratamento $110 \mathrm{~kg} \mathrm{~N}$ ciclo $^{-1}$ em função da lâmina de irrigação

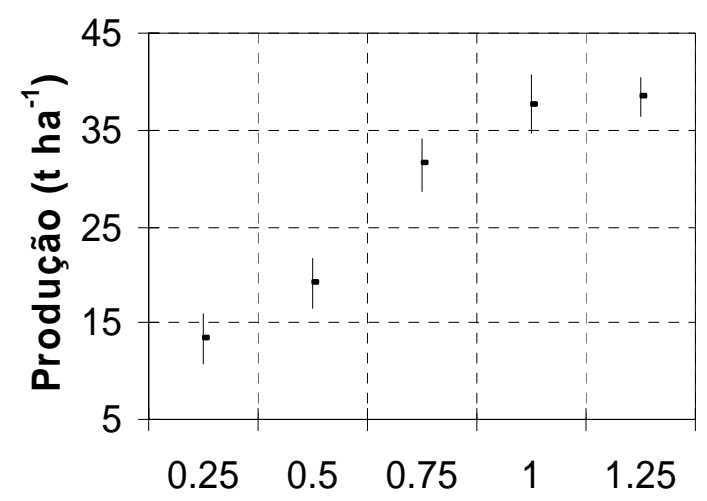

Figura 15 - Produção de forragem para o tratamento $270 \mathrm{~kg} \mathrm{~N}$ ciclo $^{-1}$ em função da lâmina de irrigação 


\subsection{Avaliação do efeito da adubação na produção de forragem}

Observa-se que com o uso da adubação nitrogenada a produção total de matéria seca do capim Tanzânia no período de coleta dos dados, aumentou linearmente em função das doses empregadas até o tratamento $\mathrm{D}_{270}$, com acúmulo de $2700 \mathrm{~kg}$ de $\mathrm{N} \mathrm{ha}^{-1}$, produzindo cerca de $42 \mathrm{t}$ de $\mathrm{MS} \mathrm{ha}^{-1}\left(\mathrm{~L}_{125}\right)$ (Figuras 16, 17, 18, 19 e 20) e, o suprimento de água no solo tem papel importante na recuperação do nitrogênio pelo capim Tanzânia. Trabalhos realizados com aveia de inverno estudando quatro doses de nitrogênio (25, 50, 75 e $100 \mathrm{~kg}$ N há-1), que o aumento de $39 \mathrm{~mm}$ (509 para $548 \mathrm{~mm}$ ) no suprimento de água no solo, melhorou a taxa de recuperação do nitrogênio para todas as doses utilizadas. Porém, neste mesmo experimento, o aumento de $90 \mathrm{~mm}$ (509 para $599 \mathrm{~mm}$ ) não foi observado efeito significativo na produção (Benbi, 1990) citado por Soria, (2002).

O incremento positivo na produção de forragem em relação a doses de adubação nitrogenada apresentou efeito significativo em diferentes gramíneas e foi observada em vários trabalhos presente na literatura Soria, (2002), Pinheiro et al. (2001), Cunha et al. (2001), Werner et al. (1996) e Monteiro \& Werner (1977). Vicente Chandler et al. (1962) trabalhando com P. maximum (ciclo de 60 dias) sob as seguintes doses de adubação nitrogenada: 0, 200, 400, 800 e $1600 \mathrm{~kg} \mathrm{~N} \mathrm{ha}^{-1}$ ano $^{-1}$, observou efeito linear entre o incremento de produção e as doses de adubação nitrogenadas. 

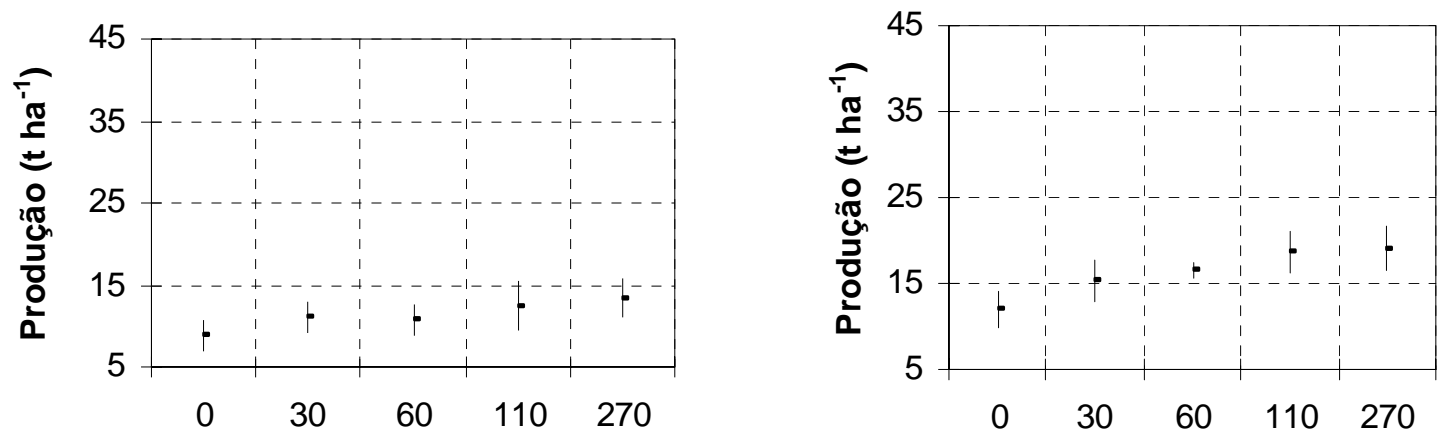

Figura 16 - Produção de forragem 25\% ET Figura 17 - Produção de forragem 50\% ET em função da adubação em função da adubação nitrogenada (kg N ciclo $^{-1}$ ) nitrogenada (kg N ciclo ${ }^{-1}$ )
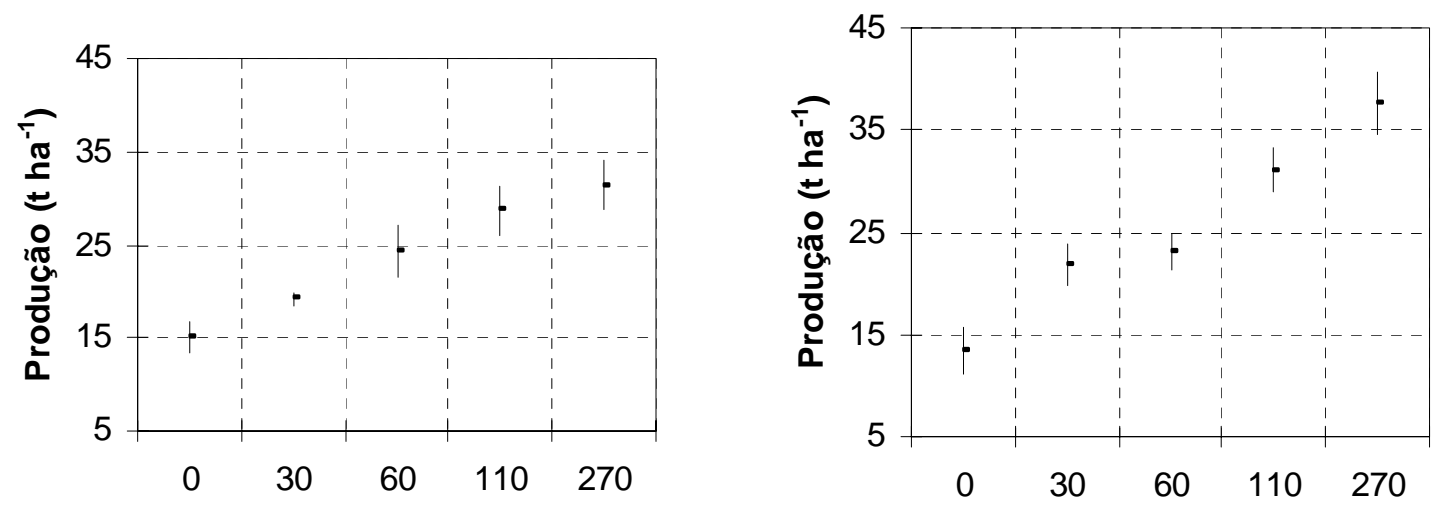

Figura 18 - Produção de forragem 75\% ET Figura 19 - Produção de forragem 100\% ET em função da adubação em função da adubação nitrogenada $\left(\mathrm{kg} \mathrm{N} \mathrm{ciclo}^{-1}\right) \quad$ nitrogenada $\left(\mathrm{kg} \mathrm{N} \mathrm{ciclo}{ }^{-1}\right)$

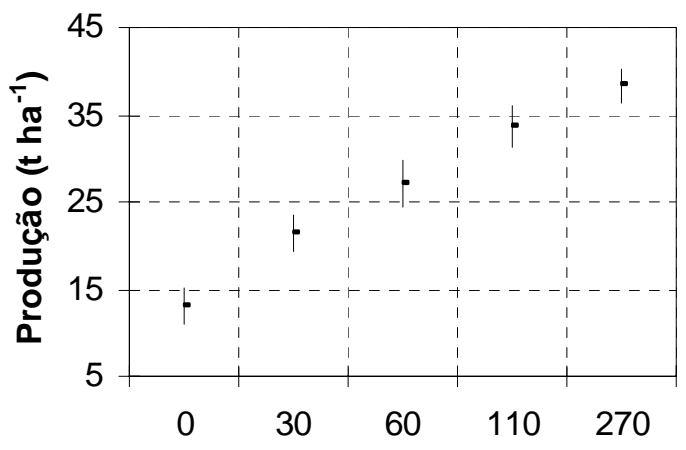

Figura 20 - Produção de forragem 125\% ET em função da adubação nitrogenada (kg N ciclo $^{-1}$ ) 


\subsection{Avaliação do efeito conjunto da irrigação e adubação nitrogenada na produção de forragem}

Nas Figuras 21, 22, 23, 24, 25, 26, 27, 28, 29, 30 e 31 pode ser observado o efeito conjunto da irrigação e adubação nitrogenada para os ciclos 1 a 10 do capim Tanzânia. Observa-se que o quarto ciclo de coleta apresentou a maior temperatura $\left(24.4^{\circ} \mathrm{C}\right)$ e a produção do capim Tanzânia foi a maior produção em relação aos demais ciclos, o que está relacionado com a presença de condições favoráveis para o desenvolvimento do capim com elevada temperatura média e radiação solar. Segundo Gomide et al. (1999), o crescimento das plantas superiores fundamenta-se na conversão de energia luminosa em energia química, cuja intensidade é proporcional à interceptação e captura da luz pelo dossel da cultura e fatores do meio, principalmente radiação solar e temperatura, condicionam os valores dos índices de crescimento vegetal. Altas temperaturas favorecem a rápida expansão de folhas e, conseqüentemente favorecem o desenvolvimento da cultura. 
Tabela 5 - Média de produção de forragem do capim Tanzânia nas 4 repetições ( MS ha $^{-1}$ ), em função dos níveis de adubação nitrogenada e deficiência hídrica, em diferentes períodos de coleta

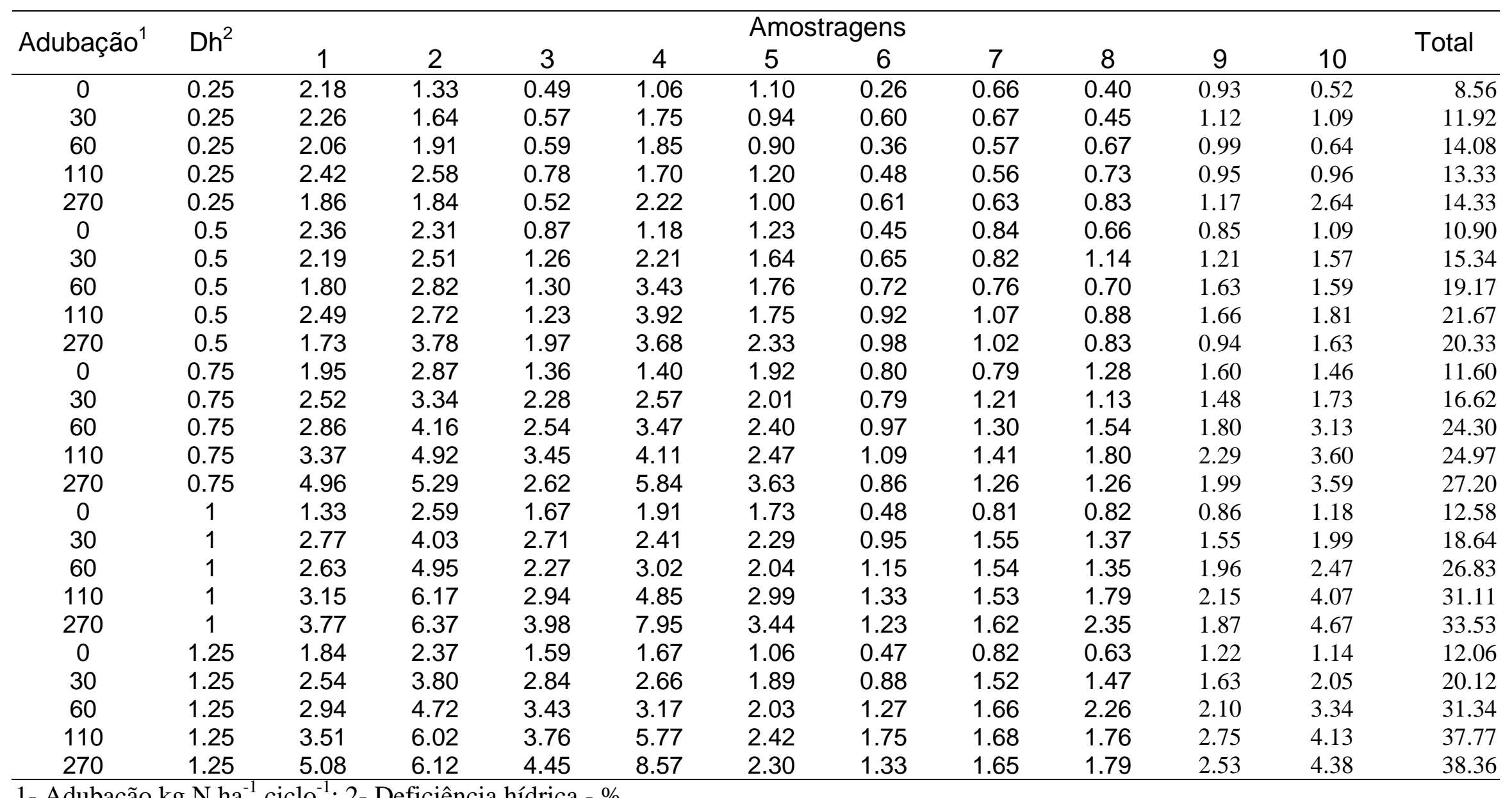




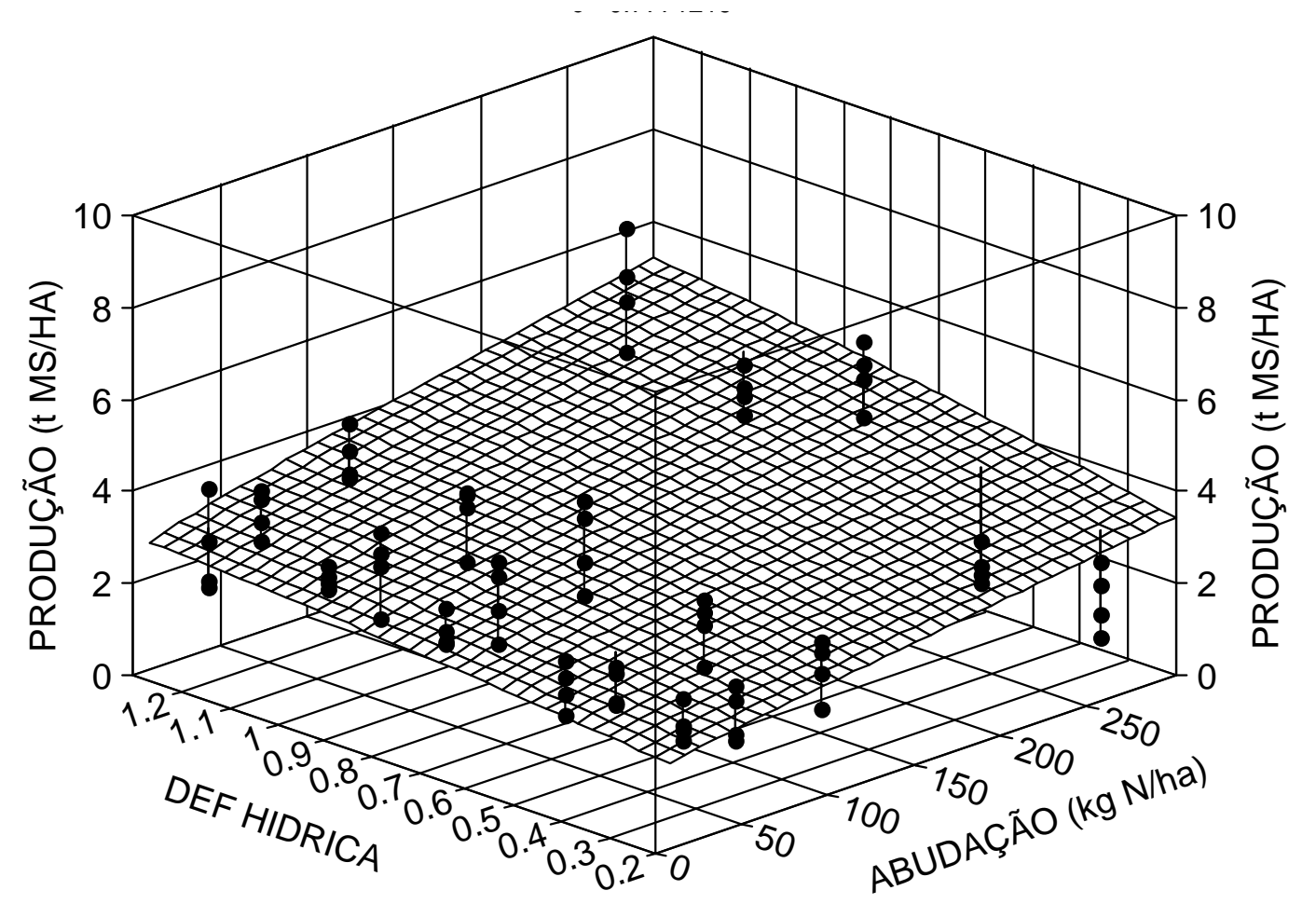

Figura 21 - Produção de forragem (t MS ha ${ }^{-1}$ ) do capim Tanzânia no ciclo 1 de 30/10 a 06/12/2002 nos 4 blocos avaliados, para os tratamentos com lâmina de irrigação $\mathrm{L}_{25}, \mathrm{~L}_{50}, \mathrm{~L}_{75}, \mathrm{~L}_{100}$ e $\mathrm{L}_{125} \%$ da $\mathrm{ET}_{\text {Testemunha }}$ em comparação com as doses de adubação nitrogenada $\left(\mathrm{D}_{0}, \mathrm{D}_{30}, \mathrm{D}_{60}, \mathrm{D}_{110}\right.$ e $\mathrm{D}_{270} \mathrm{~kg} \mathrm{~N} \mathrm{ha}^{-1}$ ciclo $\left.^{-1}\right)$ 


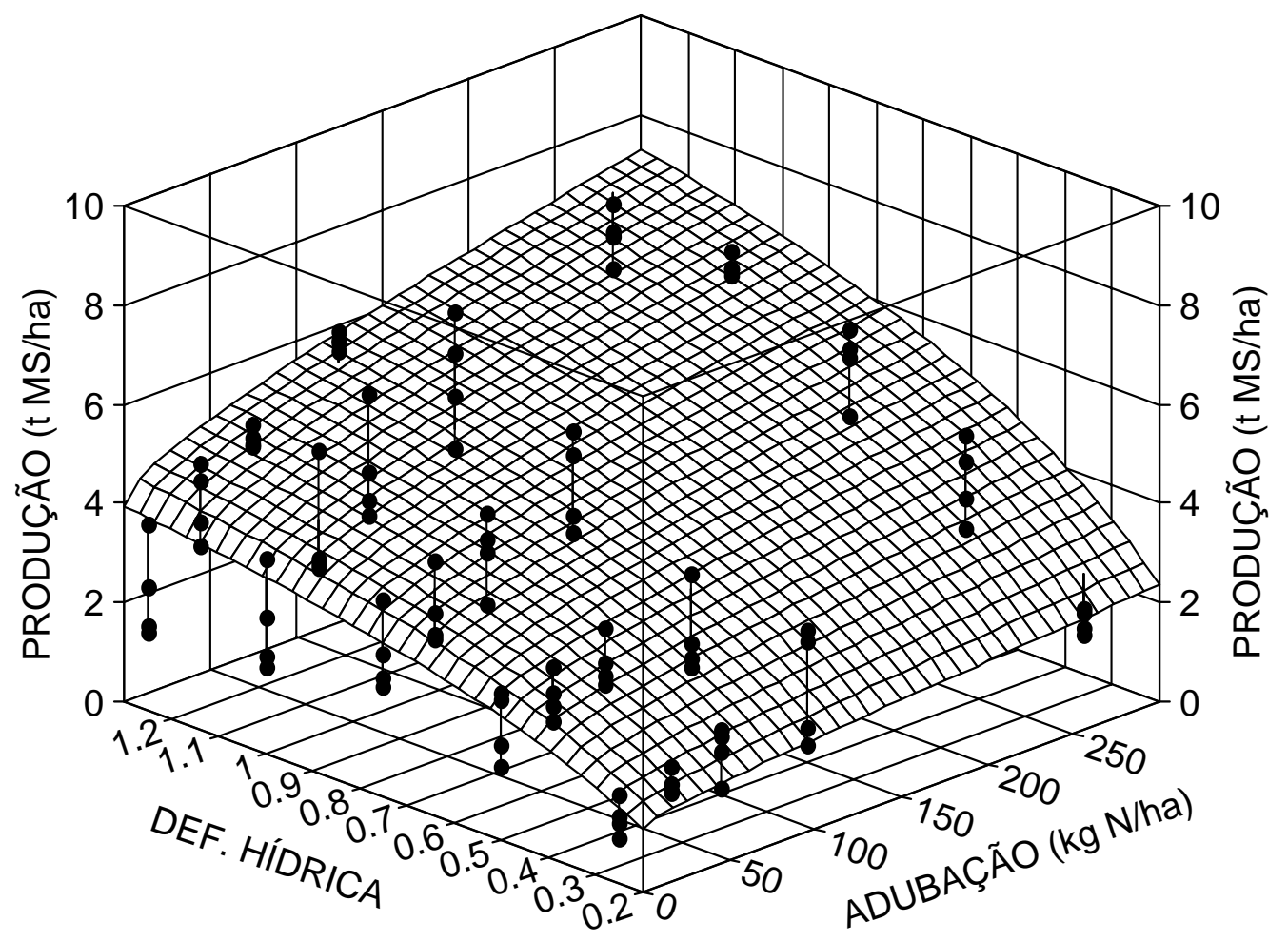

Figura 22 - Produção de forragem (t MS ha ${ }^{-1}$ ) do capim Tanzânia no ciclo 2 de 07/12/2002 a 10/01/2003 nos 4 blocos avaliados, para os tratamentos com lâmina de irrigação $\mathrm{L}_{25}, \mathrm{~L}_{50}, \mathrm{~L}_{75}$, $\mathrm{L}_{100}$ e $\mathrm{L}_{125} \%$ da $\mathrm{ET}_{\text {Testemunha }}$ em comparação com as doses de adubação nitrogenada $\left(\mathrm{D}_{0}, \mathrm{D}_{30}, \mathrm{D}_{60}, \mathrm{D}_{110}\right.$ e $\mathrm{D}_{270} \mathrm{~kg} \mathrm{~N}$ ha ${ }^{-1}$ ciclo $^{-1}$ ) 


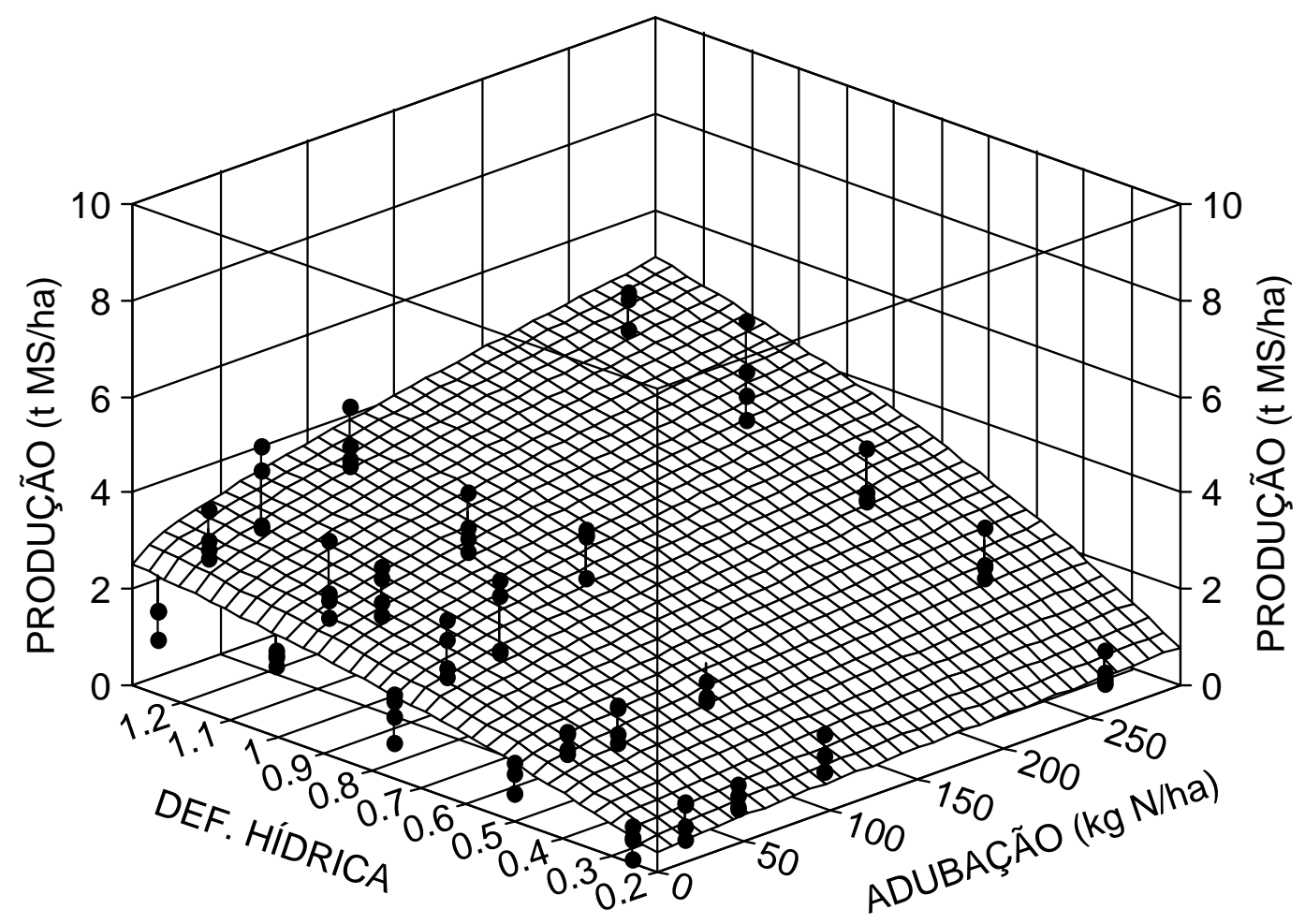

Figura 23 - Produção de forragem (t MS ha ${ }^{-1}$ ) do capim Tanzânia no ciclo 3 de 11/01 a 15/02/2003 nos 4 blocos avaliados, para os tratamentos com lâmina de irrigação $\mathrm{L}_{25}, \mathrm{~L}_{50}, \mathrm{~L}_{75}, \mathrm{~L}_{100}$ e $\mathrm{L}_{125} \%$ da $\mathrm{ET}_{\text {Testemunha }}$ em comparação com as doses de adubação nitrogenada $\left(\mathrm{D}_{0}, \mathrm{D}_{30}, \mathrm{D}_{60}, \mathrm{D}_{110}\right.$ e $\mathrm{D}_{270} \mathrm{~kg} \mathrm{~N} \mathrm{ha}^{-1}$ ciclo $\left.^{-1}\right)$ 


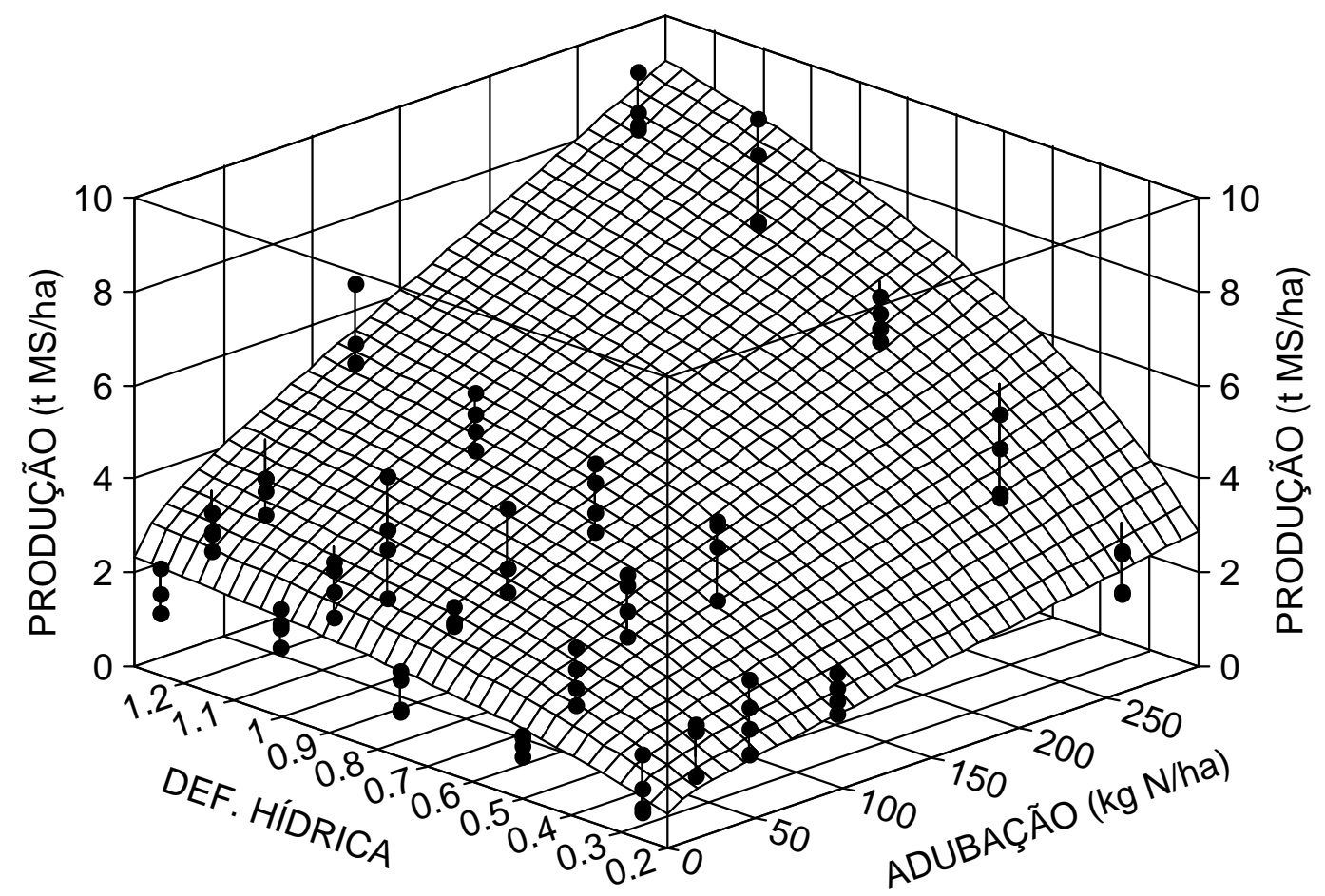

Figura 24 - Produção de forragem (t MS ha ${ }^{-1}$ ) do capim Tanzânia no ciclo 4 de 16/02 a 22/03/2003 nos 4 blocos avaliados, para os tratamentos com lâmina de irrigação $\mathrm{L}_{25}, \mathrm{~L}_{50}, \mathrm{~L}_{75}, \mathrm{~L}_{100}$ e $\mathrm{L}_{125} \%$ da $\mathrm{ET}_{\text {Testemunha }}$ em comparação com as doses de adubação nitrogenada $\left(\mathrm{D}_{0}, \mathrm{D}_{30}, \mathrm{D}_{60}, \mathrm{D}_{110}\right.$ e $\mathrm{D}_{270} \mathrm{~kg} \mathrm{~N} \mathrm{ha}^{-1}$ ciclo $\left.^{-1}\right)$ 


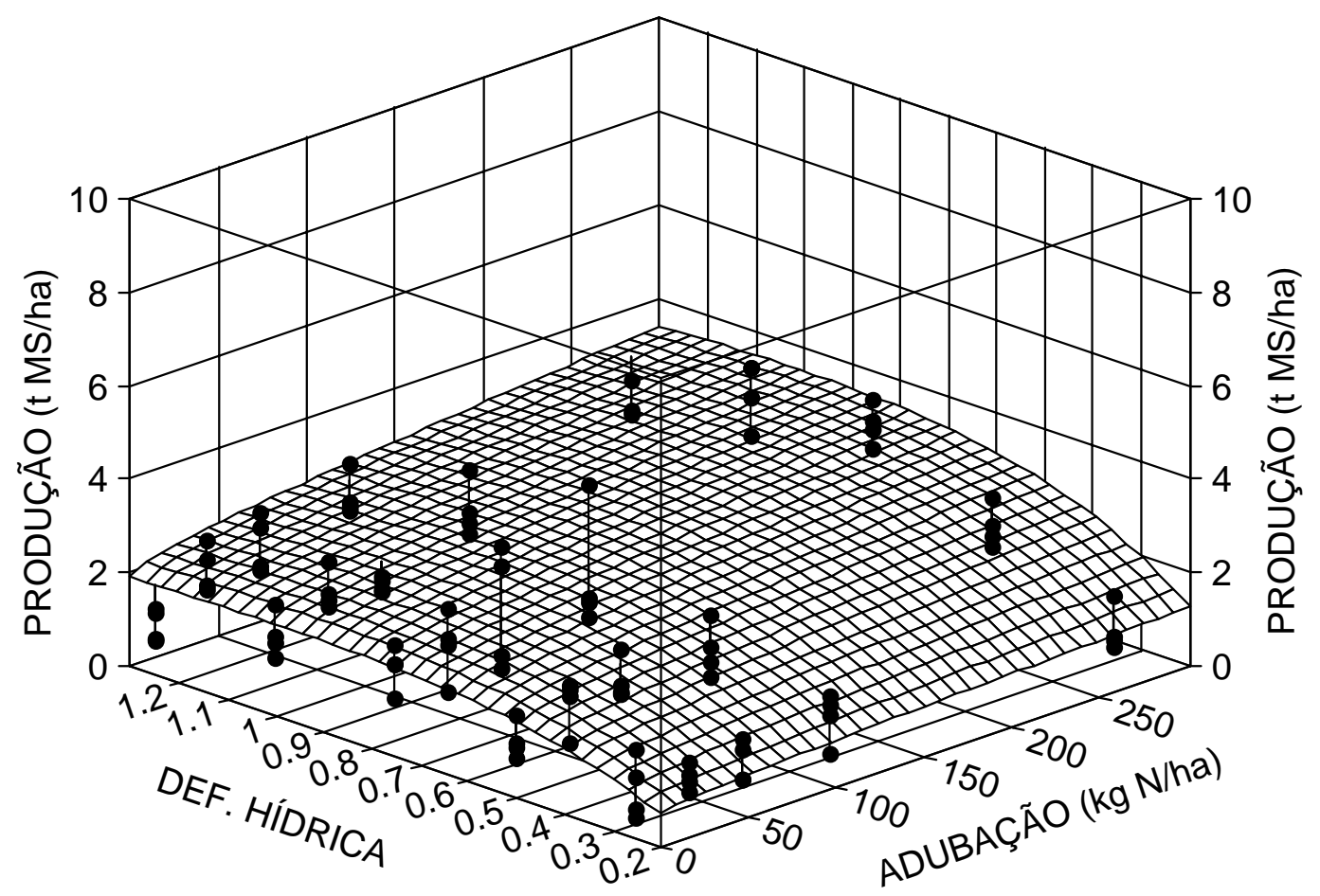

Figura 25 - Produção de forragem (t MS ha ${ }^{-1}$ ) do capim Tanzânia no ciclo 5 de 23/03 a 26/04/2003 nos 4 blocos avaliados, para os tratamentos com lâmina de irrigação $\mathrm{L}_{25}, \mathrm{~L}_{50}, \mathrm{~L}_{75}, \mathrm{~L}_{100}$ e $\mathrm{L}_{125} \%$ da $\mathrm{ET}_{\text {Testemunha }}$ em comparação com as doses de adubação nitrogenada $\left(\mathrm{D}_{0}, \mathrm{D}_{30}, \mathrm{D}_{60}, \mathrm{D}_{110}\right.$ e $\mathrm{D}_{270} \mathrm{~kg} \mathrm{~N} \mathrm{ha}^{-1}$ ciclo $\left.^{-1}\right)$ 


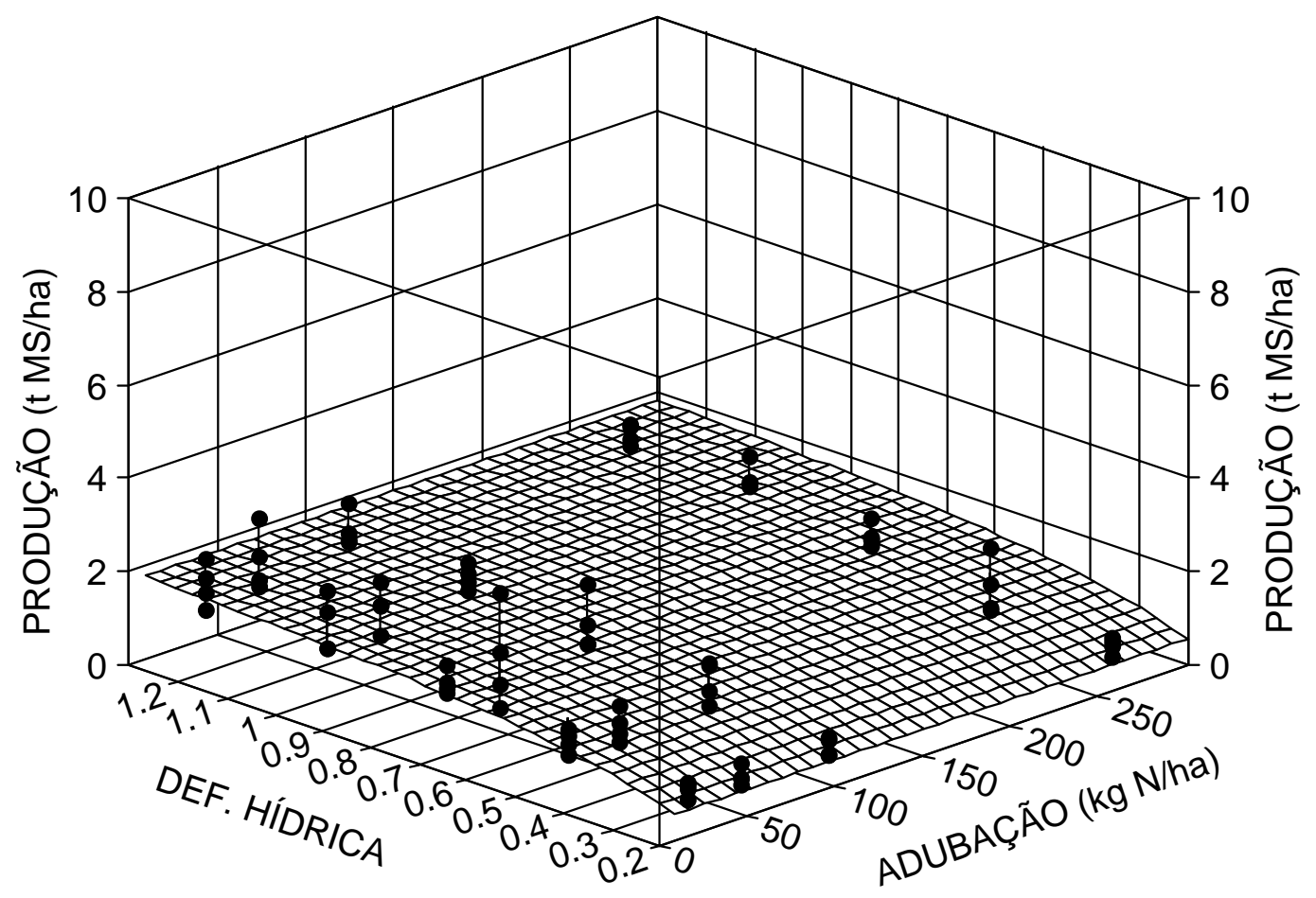

Figura 26 - Produção de forragem (t MS ha ${ }^{-1}$ ) do capim Tanzânia no ciclo 6 de 27/04 a 31/05/2003 nos 4 blocos avaliados, para os tratamentos com lâmina de irrigação $\mathrm{L}_{25}, \mathrm{~L}_{50}, \mathrm{~L}_{75}, \mathrm{~L}_{100}$ e $\mathrm{L}_{125} \%$ da $\mathrm{ET}_{\text {Testemunha }}$ em comparação com as doses de adubação nitrogenada $\left(\mathrm{D}_{0}, \mathrm{D}_{30}, \mathrm{D}_{60}, \mathrm{D}_{110}\right.$ e $\mathrm{D}_{270} \mathrm{~kg} \mathrm{~N}$ ha $^{-1}$ ciclo $\left.{ }^{-1}\right)$ 


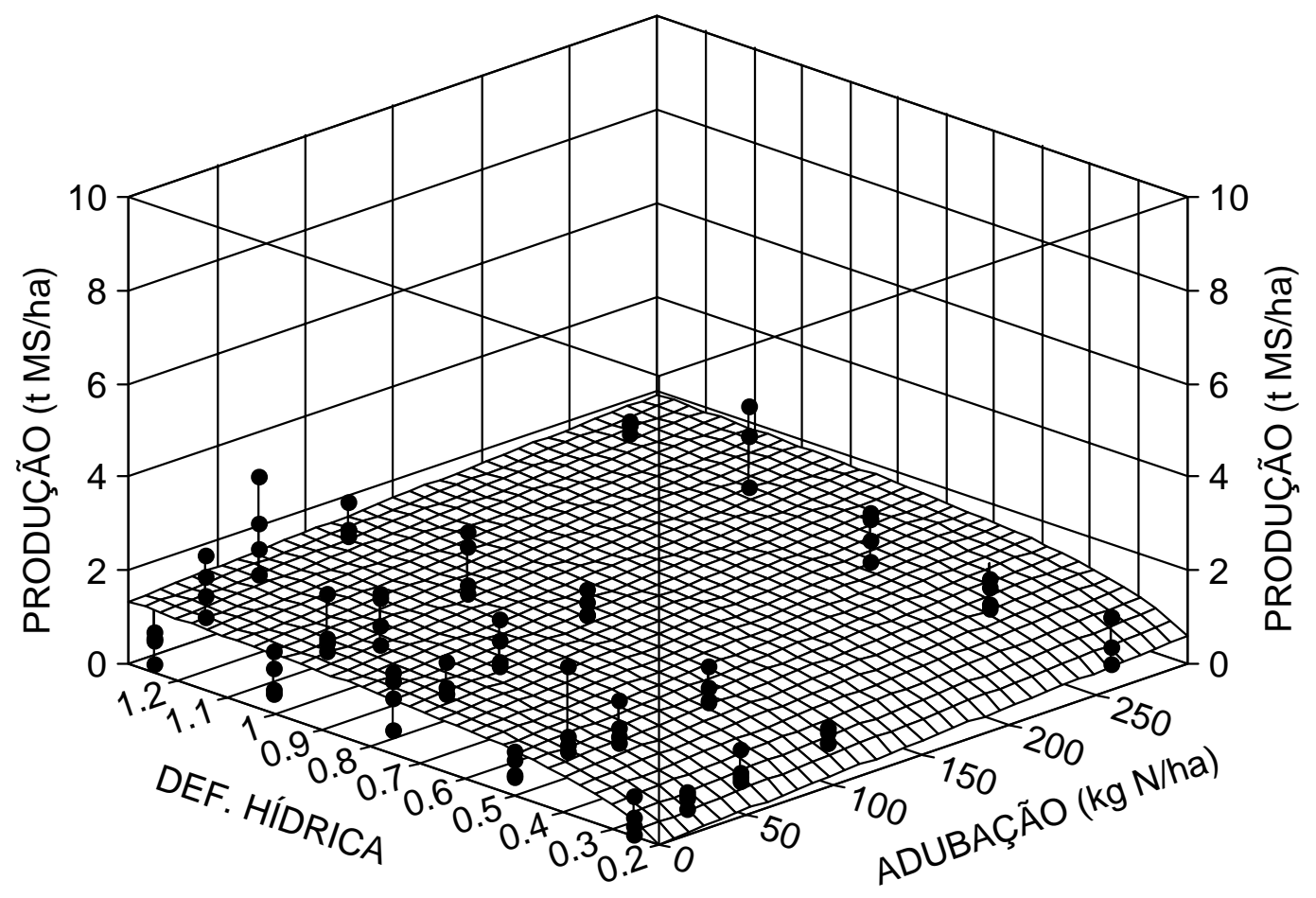

Figura 27 - Produção de forragem (t MS ha ${ }^{-1}$ ) do capim Tanzânia no ciclo 7 de 01/06 a 05/07/2003 nos 4 blocos avaliados, para os tratamentos com lâmina de irrigação $\mathrm{L}_{25}, \mathrm{~L}_{50}, \mathrm{~L}_{75}, \mathrm{~L}_{100}$ e $\mathrm{L}_{125} \%$ da $\mathrm{ET}_{\text {Testemunha }}$ em comparação com as doses de adubação nitrogenada $\left(\mathrm{D}_{0}, \mathrm{D}_{30}, \mathrm{D}_{60}, \mathrm{D}_{110}\right.$ e $\mathrm{D}_{270} \mathrm{~kg} \mathrm{~N} \mathrm{ha}^{-1}$ ciclo $\left.^{-1}\right)$ 


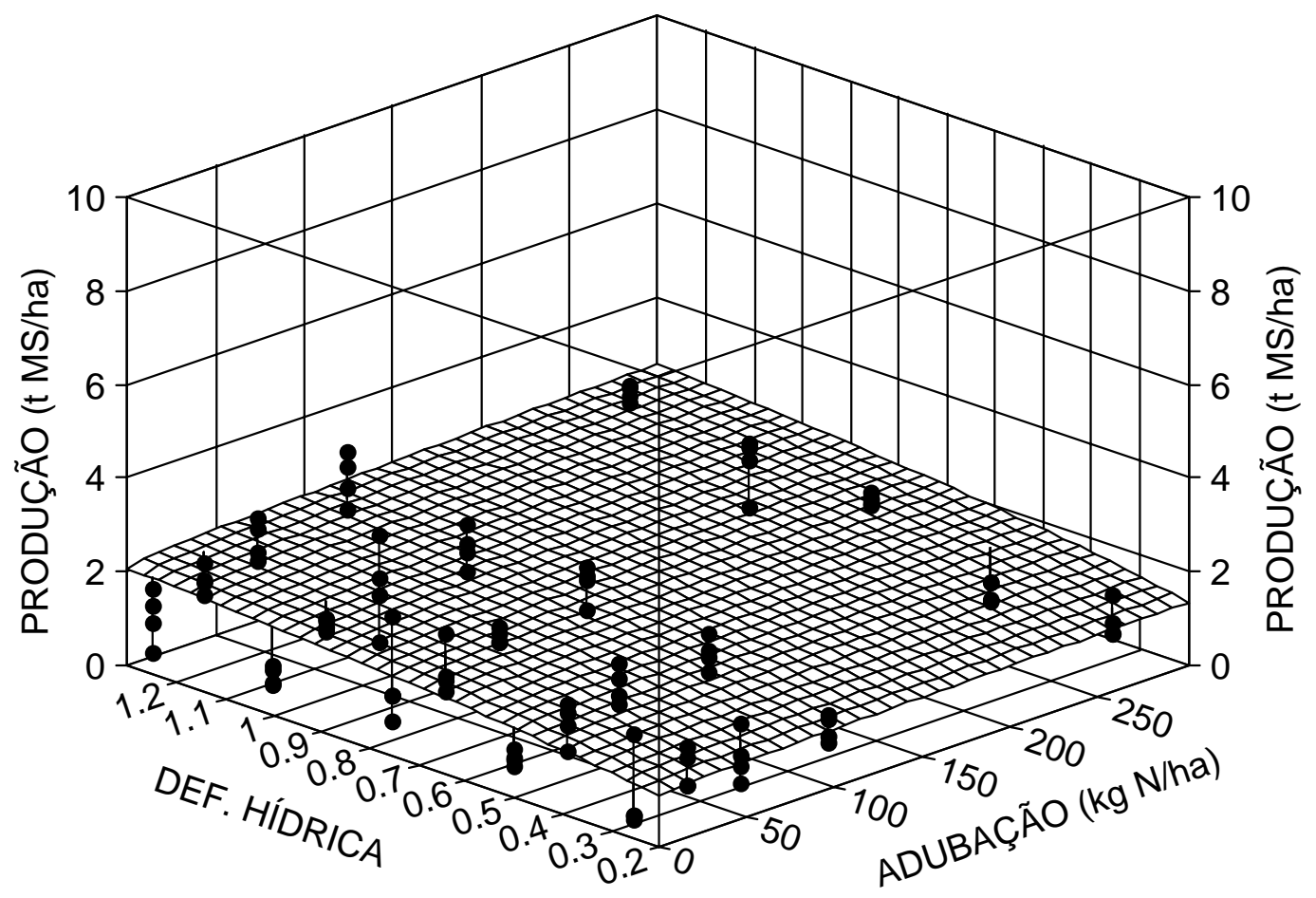

Figura 28 - Produção de forragem (t MS ha ${ }^{-1}$ ) do capim Tanzânia no ciclo 8 de 06/07 a 09/08/2003 nos 4 blocos avaliados, para os tratamentos com lâmina de irrigação $\mathrm{L}_{25}, \mathrm{~L}_{50}, \mathrm{~L}_{75}, \mathrm{~L}_{100}$ e $\mathrm{L}_{125} \%$ da $\mathrm{ET}_{\text {Testemunha }}$ em comparação com as doses de adubação nitrogenada $\left(\mathrm{D}_{0}, \mathrm{D}_{30}, \mathrm{D}_{60}, \mathrm{D}_{110}\right.$ e $\mathrm{D}_{270} \mathrm{~kg} \mathrm{~N} \mathrm{ha}^{-1}$ ciclo $\left.^{-1}\right)$ 


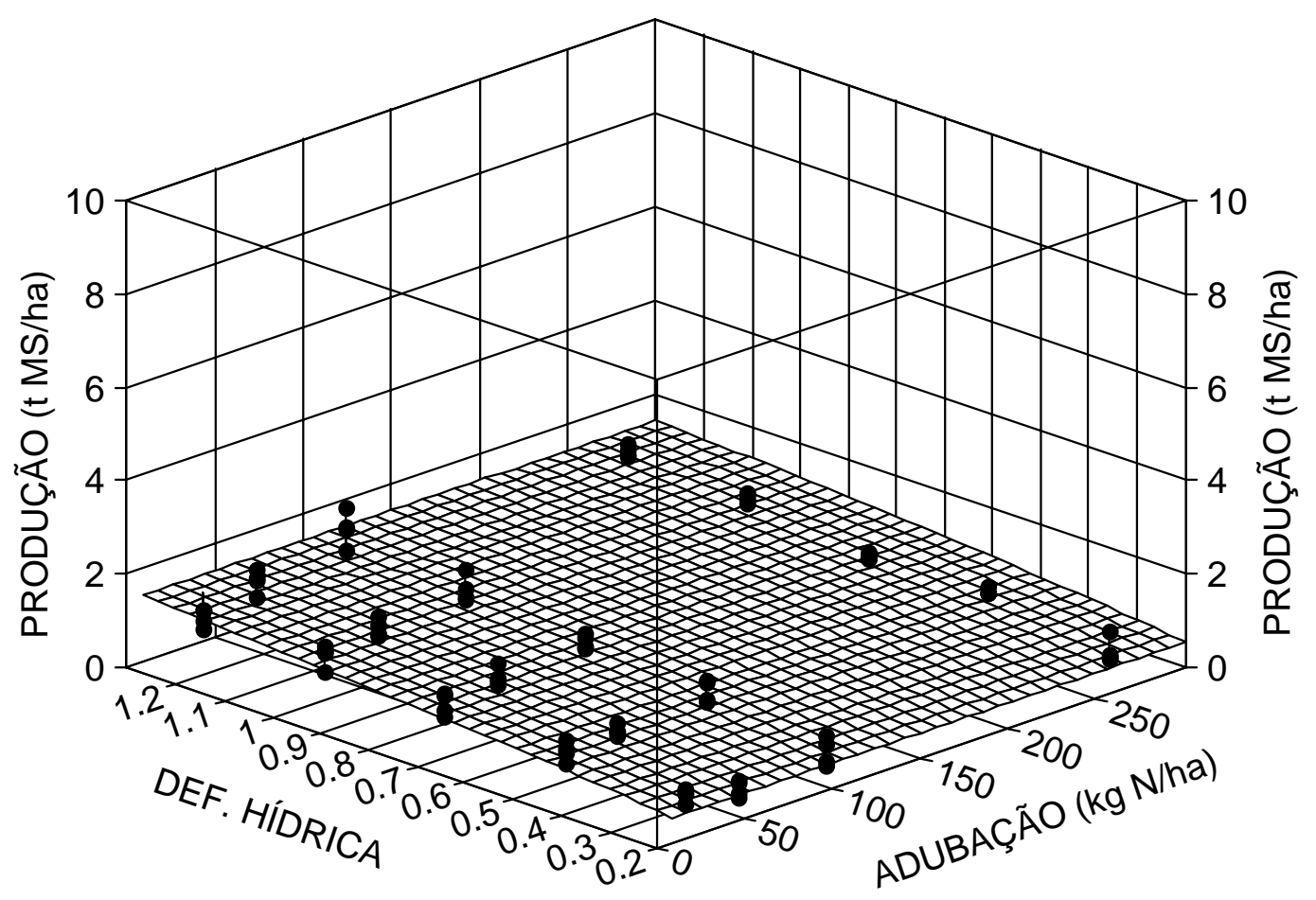

Figura 29 - Produção de forragem (t MS ha ${ }^{-1}$ ) do capim Tanzânia no ciclo 9 de 10/08 a 13/09/2003 nos 4 blocos avaliados, para os tratamentos com lâmina de irrigação $\mathrm{L}_{25}, \mathrm{~L}_{50}, \mathrm{~L}_{75}, \mathrm{~L}_{100}$ e $\mathrm{L}_{125} \%$ da $\mathrm{ET}_{\text {Testemunha }}$ em comparação com as doses de adubação nitrogenada $\left(\mathrm{D}_{0}, \mathrm{D}_{30}, \mathrm{D}_{60}, \mathrm{D}_{110}\right.$ e $\mathrm{D}_{270} \mathrm{~kg} \mathrm{~N}$ ha $^{-1}$ ciclo $\left.^{-1}\right)$ 


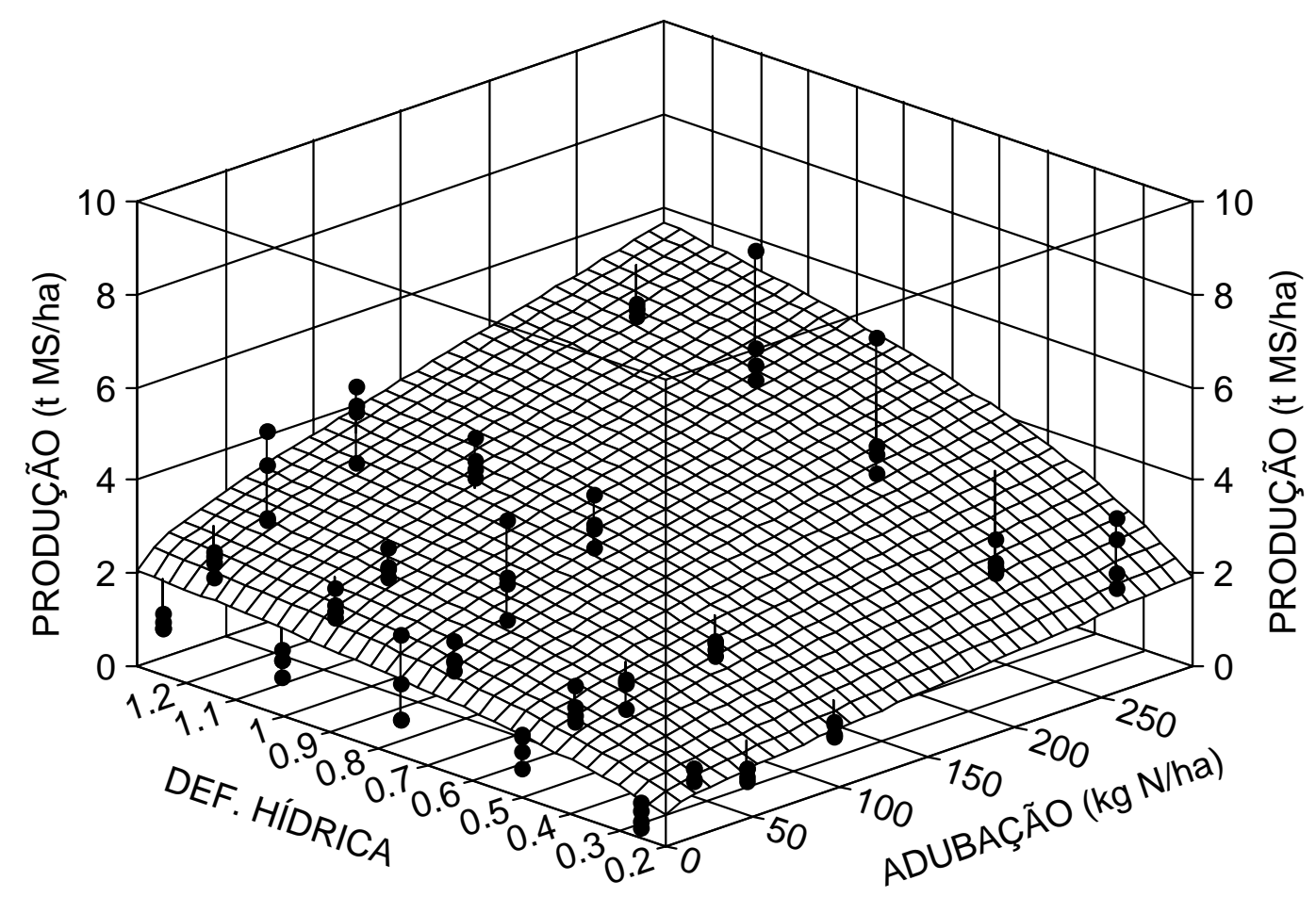

Figura 30 - Produção de forragem (t MS ha ${ }^{-1}$ ) do capim Tanzânia no ciclo 10 de 14/09 a 18/10/2003 nos 4 blocos avaliados, para os tratamentos com lâmina de irrigação $\mathrm{L}_{25}, \mathrm{~L}_{50}, \mathrm{~L}_{75}, \mathrm{~L}_{100}$ e $\mathrm{L}_{125} \%$ da $\mathrm{ET}_{\text {Testemunha }}$ em comparação com as doses de adubação nitrogenada $\left(\mathrm{D}_{0}, \mathrm{D}_{30}, \mathrm{D}_{60}, \mathrm{D}_{110}\right.$ e $\mathrm{D}_{270} \mathrm{~kg} \mathrm{~N} \mathrm{ha}^{-1}$ ciclo $\left.^{-1}\right)$ 


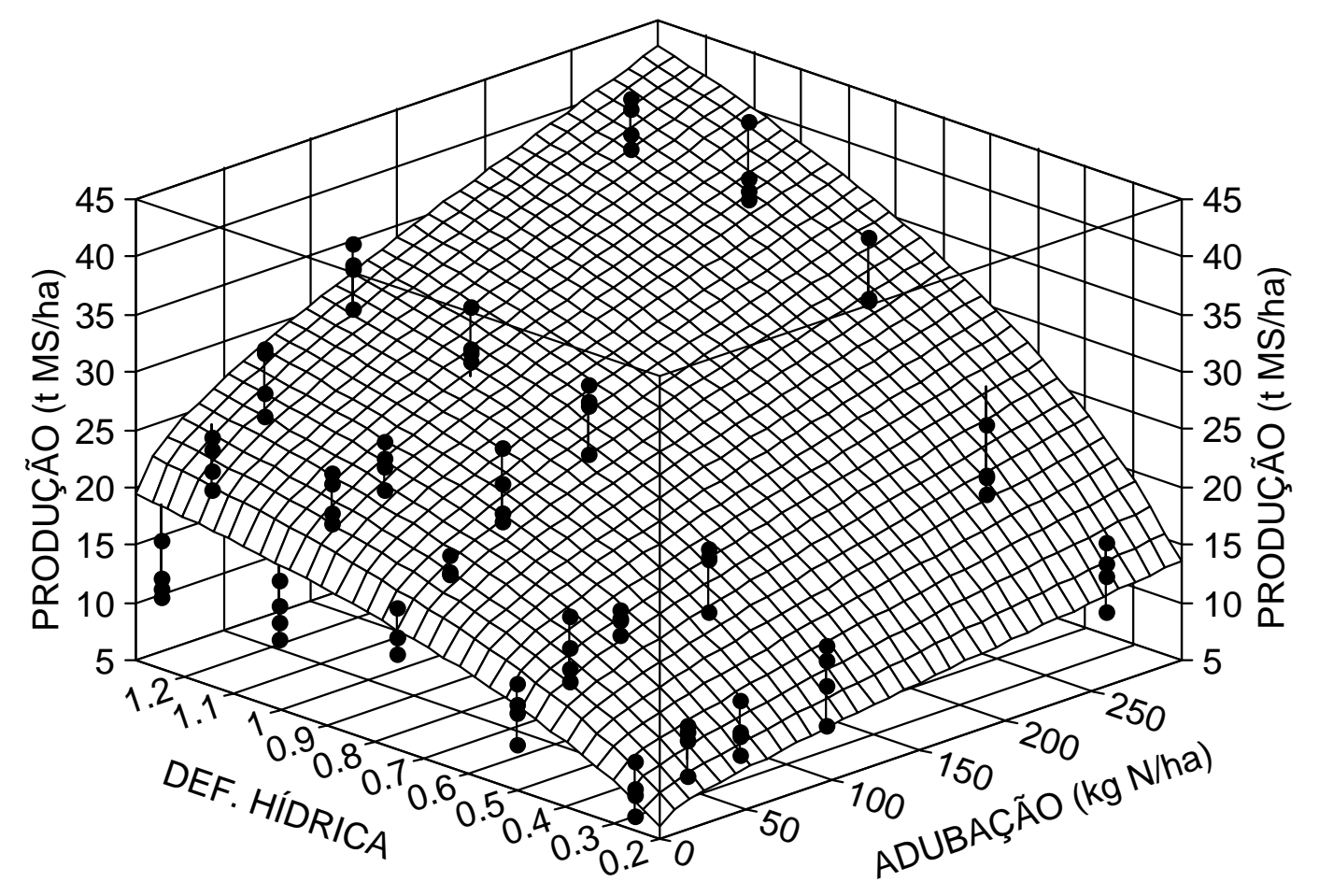

Figura 31 - Comparação da produção de matéria seca (t MS ha ${ }^{-1}$ ) no ciclo 10 de 14/09 a 18/10/2003 nos 4 blocos avaliados, para os tratamentos com a mesma lâmina de irrigação $\mathrm{L}_{25}, \mathrm{~L}_{50}, \mathrm{~L}_{75}, \mathrm{~L}_{100}$ e $\mathrm{L}_{125} \%$ da $\mathrm{ET}_{\text {Testemunha }}$ em comparação com as doses de adubação nitrogenada $\left(\mathrm{D}_{0}, \mathrm{D}_{30}, \mathrm{D}_{60}, \mathrm{D}_{110}\right.$ e $\mathrm{D}_{270} \mathrm{~kg}$ N.ha ${ }^{-1}$ ano $^{-1}$ ciclo $^{-1}$ ) 
Tabela 6. Modelo matemático de ajuste de superfície de resposta ao comportamento da produção de forragem do capim Tanzânia submetido a lâminas de irrigação e doses de adubação em 10 ciclos com os respectivos valores do coeficiente de correlação ( $\left.r^{2}\right)$ e valor F

$$
P=e^{a+b x^{0.5}+\frac{c}{y^{0.5}}}
$$

\begin{tabular}{|c|c|c|c|c|c|c|}
\hline \multirow{2}{*}{ Ciclo } & \multicolumn{3}{|c|}{ Parâmetros do modelo } & \multicolumn{3}{|c|}{ Parâmetros estatísticos } \\
\hline & a & $\mathrm{b}$ & c & $r^{2}$ & Fit Std Err & $\mathrm{F}$ \\
\hline 1 & & & & & & $*$ \\
\hline 2 & 2.101 & 0.035 & -0.834 & 0.70 & 0.92 & 113.3 ** \\
\hline 3 & 2.107 & 0.039 & -1.350 & 0.77 & 0.59 & $168.3 * *$ \\
\hline 4 & 1.589 & 0.077 & -0.838 & 0.82 & 0.84 & $234.3 * *$ \\
\hline 5 & & & & & & $*$ \\
\hline 6 & & & & & & * \\
\hline 7 & & & & & & * \\
\hline 8 & & & & & & $*$ \\
\hline 9 & & & & & & $*$ \\
\hline 10 & 1.419 & 0.058 & -0.788 & 0.612 & 0.837 & $76.7 * *$ \\
\hline Total & 3.705 & 0.045 & -0.841 & 0.86 & 3.346 & $299.4 * *$ \\
\hline
\end{tabular}

* Não Significativo; ** Significativo ao nível de 1\% de probabilidade.

As respostas de produção de forragem do capim Tanzânia em função dos ciclos analisados podem ser observados através do gráfico de isolinhas na Figura 32. Quanto maior a intensidade do tom vermelho, maior a produção de forragem. O ciclo 4 foi o que apresentou maior produção, enquanto que o ciclo 6,7 e 8 foram praticamente equivalentes na produtividade, que voltou a subir nos ciclos 9 e 10, devido aos efeitos climáticos deste períodos. 

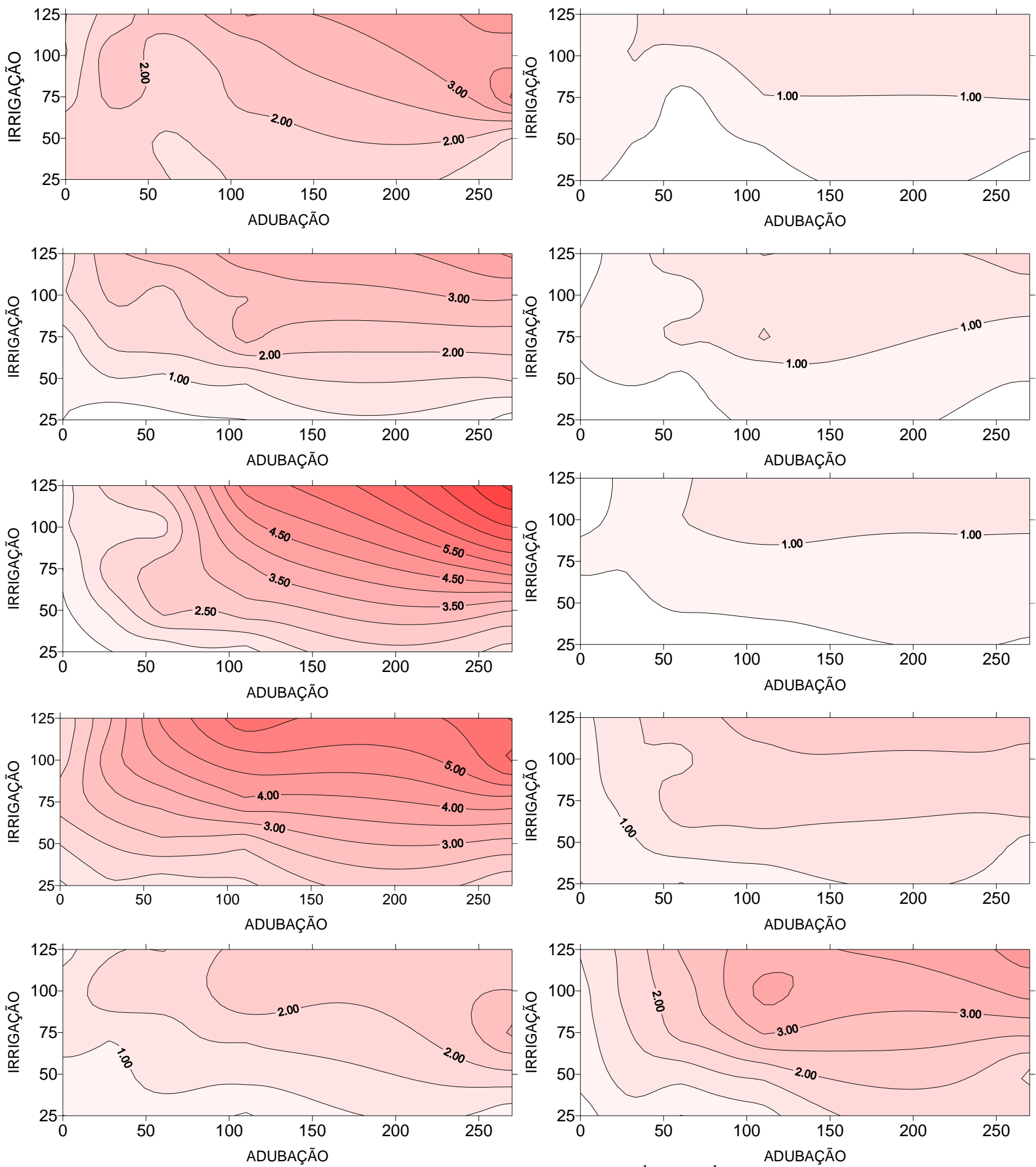

Figura 32 - Isolinhas da produção de forragem (t MS ha ${ }^{-1}$ ciclo $^{-1}$ ) em Capim Tanzânia em função do ciclo e quantidades de água e nitrogênio 


\subsection{Estacionalidade de produção do capim Tanzânia}

Através da divisão do ano em duas estações: "verão" - meados de outubro a meados de abril (ciclos 1, 2, 3, 4 e 10) e; "inverno" - meados de maio até meados de setembro (ciclos 5, 6, 7, 8 e 9), verifica-se que nos tratamentos $D_{0}$ e $D_{30}$, a produção foi de 65 e $35 \%$ no verão e inverno respectivamente, enquanto que no tratamento $\mathrm{D}_{270}$, a produção de forragem no verão foi de $71 \%$ e $28 \%$ no inverno (Tabela 5). Desta forma, quanto maior o nível de intensificação da exploração de forragem, com a utilização da irrigação e adubação nitrogenada, maior será a estacionalidade de produção. Segundo Balsalobre et al., (2002), em regiões onde a temperatura é limitante para o desenvolvimento das gramíneas forrageiras, a irrigação de pastagens aumenta o potencial de produção de forragem no período de verão, provocando aumento da estacionalidade de produção.

A ocorrência da estacionalidade na produção de massa seca total em Piracicaba é algo característico da região, onde o efeito da irrigação e o uso de nitrogênio são técnicas que não se mostraram capazes de diminuírem o efeito dos fatores climáticos na produção do capim Tanzânia no período do inverno (Soria, 2002).

Porém, não foi observada diferença significativa na estacionalidade de produção nos tratamentos sem deficiência hídrica $\left(\mathrm{L}_{100}\right.$ e $\left.\mathrm{L}_{125}\right)$, em relação aos tratamentos com deficiência hídrica $\left(\mathrm{L}_{75}, \mathrm{~L}_{50}\right.$ e $\left.\mathrm{L}_{100}\right)$.

A irrigação teve efeito positivo na produção de forragem sem, contudo sem alterar substancialmente a estacionalidade da produção (Soria, 2002, Pinheiro et al., 2001, Botrel et al., 1991, Machado et al., 1983, Ghelfi Filho, 1976; 1972).

Pedreira (1981), no Estado de São Paulo, estudando a estacionalidade de produção com quatro espécies, entre as quais o capim colonião verificou que $90 \%$ da produção anual de forragem estava concentrada no verão. Ghelfi Filho (1972), trabalhando com capim elefante irrigado, obteve $76 \%$ da produção de forragem no verão e $24 \%$ no inverno, resultados estes próximos aos tratamentos $\mathrm{D}_{0}$ e $\mathrm{D}_{30}$ (Tabela 5). 
Tabela 7 - Produção de forragem no período de verão (ciclos 1, 2, 3, 4 e 10) e inverno (ciclos 5, 6, 7, 8 e 9) em capim Tanzânia

\begin{tabular}{|c|c|c|c|c|c|c|}
\hline \multirow[t]{2}{*}{ Adubação } & \multirow{2}{*}{$\begin{array}{c}\text { Lâmina } \\
\text { \% }\end{array}$} & \multicolumn{2}{|c|}{ Verão } & \multicolumn{2}{|c|}{ Inverno } & \multirow{2}{*}{$\begin{array}{l}\text { Total } \\
\qquad \text { t ha }^{-1}\end{array}$} \\
\hline & & $\mathrm{tha}^{-1}$ & $\%$ & $\mathrm{t} \mathrm{ha}^{-1}$ & $\%$ & \\
\hline 0 & 0.25 & 5.71 & 65.7 & 2.98 & 34.3 & 8.69 \\
\hline 0 & 0.5 & 7.82 & 65.6 & 4.10 & 34.4 & 11.92 \\
\hline 0 & 0.75 & 9.03 & 60.0 & 6.02 & 40.0 & 15.05 \\
\hline 0 & 1 & 8.67 & 64.4 & 4.79 & 35.6 & 13.46 \\
\hline 0 & 1.25 & 8.61 & 66.2 & 4.40 & 33.8 & 13.01 \\
\hline 30 & 0.25 & 7.25 & 65.2 & 3.87 & 34.8 & 11.12 \\
\hline 30 & 0.5 & 9.74 & 63.5 & 5.60 & 36.5 & 15.34 \\
\hline 30 & 0.75 & 12.44 & 64.9 & 6.73 & 35.1 & 19.17 \\
\hline 30 & 1 & 13.92 & 64.0 & 7.83 & 36.0 & 21.75 \\
\hline 30 & 1.25 & 13.89 & 64.9 & 7.50 & 35.1 & 21.39 \\
\hline 60 & 0.25 & 7.07 & 66.4 & 3.57 & 33.6 & 10.63 \\
\hline 60 & 0.5 & 10.94 & 65.8 & 5.69 & 34.2 & 16.62 \\
\hline 60 & 0.75 & 16.16 & 66.5 & 8.15 & 33.5 & 24.30 \\
\hline 60 & 1 & 15.34 & 66.2 & 7.82 & 33.8 & 23.16 \\
\hline 60 & 1.25 & 17.59 & 64.9 & 9.51 & 35.1 & 27.11 \\
\hline 110 & 0.25 & 8.44 & 67.8 & 4.01 & 32.2 & 12.45 \\
\hline 110 & 0.5 & 12.16 & 65.5 & 6.40 & 34.5 & 18.56 \\
\hline 110 & 0.75 & 19.45 & 67.9 & 9.19 & 32.1 & 28.64 \\
\hline 110 & 1 & 21.18 & 68.1 & 9.94 & 31.9 & 31.11 \\
\hline 110 & 1.25 & 23.20 & 68.7 & 10.55 & 31.3 & 33.74 \\
\hline 270 & 0.25 & 9.08 & 67.8 & 4.31 & 32.2 & 13.38 \\
\hline 270 & 0.5 & 12.79 & 67.1 & 6.26 & 32.9 & 19.05 \\
\hline 270 & 0.75 & 22.30 & 71.0 & 9.13 & 29.0 & 31.43 \\
\hline 270 & 1 & 26.74 & 71.2 & 10.82 & 28.8 & 37.56 \\
\hline 270 & 1.25 & 28.59 & 74.5 & 9.77 & 25.5 & 38.36 \\
\hline
\end{tabular}




\subsection{Fator de reposta da cultura - ky}

O ky para o capim Tanzânia médio é de 0,77 a 1,18 para o tratamento $\mathrm{D}_{0}$ e, 0,76 a 0,81 para os tratamentos $D_{110}$ e $D_{270}$, porém observa-se que existe uma grande variação nos dados (Tabela 6). Segundo Doorembos \& Kassan (1979), uma avaliação dos dados experimentais de campo indica certa dispersão nos valores de ky, que se deve à imperfeição experimental e às variações de clima, nível de evapotranspiração e solo. A separação dos valores de ky, de acordo com a variação desses fatores, não contribui para a precisão atingível. Na maioria dos casos, pode-se explicar de 80 a 85\% da variação do rendimento de dados experimentais de campo.

O efeito generalizado do déficit hídrico sobre o rendimento de uma cultura é apresentado tanto para o período total de crescimento como para as fases específicas de crescimento; em geral, para o período total de crescimento a queda de rendimento tornase proporcionalmente menor ao se aumentar o déficit hídrico $(\mathrm{ky}<1)$ para culturas, tais como: alfafa e amendoim enquanto para culturas como milho e cana-de-açúcar é proporcionalmente maior $(k y>1)$. Para os períodos de específicos de crescimento, a queda de rendimento devido ao díficit hídrico durante determinado período de crescimento é relativamente pequena para o período vegetativo e o de maturação, sendo relativamente grande para o de floração e o de formação da colheita (Doorembos \& Kassan, 2000).

Observa-se que os tratamentos com menor nível de adubação nitrogenada, a resistência ao déficit hídrico do capim Tanzânia é maior e, a partir de doses com $30 \mathrm{~kg} \mathrm{~N}$ $\mathrm{ha}^{-1}$, a resistência ao déficit hídrico é menor. Este fato pode estar relacionado com o acúmulo do sistema radicular na superfície do solo, estimulado pelas adubações. Segundo Soria (2002) cerca de 80\% do sistema radicular do capim Tanzânia encontra-se nos $20 \mathrm{~cm}$ superficiais do solo. 
Tabela 8 - Coeficiente de resposta da cultura (ky) para capim Tanzânia submetido a diferentes doses de adubação nitrogenada

\begin{tabular}{|c|c|c|c|c|c|c|c|c|c|c|c|c|c|}
\hline \multirow{2}{*}{ Adub $^{1}$} & \multirow{2}{*}{ Lâmina² } & \multicolumn{10}{|c|}{ Amostragens } & \multirow{2}{*}{ Média } & \multirow{2}{*}{$\begin{array}{l}\text { Desvio } \\
\text { Padrão }\end{array}$} \\
\hline & & 1 & 2 & 3 & 4 & 5 & 6 & 7 & 8 & 9 & 10 & & \\
\hline 0 & 0.25 & 0.68 & 0.68 & 0.94 & 0.95 & 0.89 & 0.75 & 0.74 & 0.55 & 0.61 & 0.61 & 0.77 & 0.14 \\
\hline 0 & 0.5 & 1.25 & 1.30 & 1.60 & 1.24 & 1.45 & 0.90 & 1.00 & 0.68 & 0.70 & 0.90 & 1.18 & 0.30 \\
\hline 0 & 0.75 & 1.00 & 1.14 & 1.00 & 1.48 & 1.44 & 0.87 & 0.79 & 1.37 & 1.10 & 1.31 & 1.13 & 0.27 \\
\hline 30 & 0.25 & 0.78 & 0.73 & 0.94 & 0.60 & 0.72 & 0.95 & 0.24 & 0.96 & 0.64 & 0.53 & 0.74 & 0.24 \\
\hline 30 & 0.5 & 0.76 & 0.42 & 0.96 & 0.76 & 0.98 & 1.01 & 0.80 & 1.10 & 0.46 & 0.27 & 0.85 & 0.21 \\
\hline 30 & 0.75 & 0.86 & 0.79 & 0.74 & 1.08 & 0.80 & 0.45 & 0.82 & 0.47 & 0.07 & 0.50 & 0.75 & 0.21 \\
\hline 60 & 0.25 & 0.25 & 0.79 & 1.05 & 0.47 & 0.78 & 0.49 & 0.75 & 0.90 & 0.66 & 0.79 & 0.69 & 0.26 \\
\hline 60 & 0.5 & 0.42 & 0.75 & 1.07 & 0.36 & 0.57 & 0.63 & 0.95 & 0.34 & 0.68 & 1.04 & 0.64 & 0.27 \\
\hline 60 & 0.75 & 0.37 & 0.68 & 0.64 & 0.00 & 0.50 & 0.65 & 0.89 & 0.70 & 0.81 & 0.52 & 0.55 & 0.27 \\
\hline 110 & 0.25 & 0.29 & 0.82 & 0.98 & 0.52 & 0.87 & 0.92 & 0.84 & 0.84 & 0.78 & 0.95 & 0.76 & 0.23 \\
\hline 110 & 0.5 & 0.64 & 0.86 & 0.85 & 0.75 & 0.64 & 0.75 & 1.02 & 1.22 & 0.54 & 1.02 & 0.84 & 0.20 \\
\hline 110 & 0.75 & 1.00 & 0.63 & 1.20 & 1.30 & 0.76 & 0.61 & 0.62 & 0.58 & 0.97 & 1.05 & 0.84 & 0.29 \\
\hline 270 & 0.25 & 0.31 & 0.78 & 0.98 & 0.87 & 0.80 & 0.85 & 0.85 & 0.79 & 0.69 & 0.97 & 0.78 & 0.20 \\
\hline 270 & 0.5 & 0.42 & 1.12 & 1.17 & 0.38 & 0.83 & 0.61 & 0.61 & 1.02 & 0.81 & 1.01 & 0.77 & 0.31 \\
\hline 270 & 0.75 & 1.20 & 0.81 & 1.10 & 0.61 & 0.70 & 0.74 & 0.32 & 0.93 & 0.89 & 0.77 & 0.80 & 0.28 \\
\hline
\end{tabular}

1- Adubação kg N ha-1 ciclo $^{-1} ; 2$ - Deficiência hídrica - \% 


\subsection{Eficiência na utilização de água pelo capim Tanzânia}

Observa-se que quanto maior a disponibilidade de água, menor é a EUA do capim Tanzânia nos tratamentos $\mathrm{L}_{25}$ EUA foi de $36 \mathrm{~kg} \mathrm{MS} \mathrm{mm}^{-1} \mathrm{ha}^{-1}$, ou seja, para produção de $1000 \mathrm{~kg}$ de MS foram necessários $2.780 \mathrm{~m}^{3} \mathrm{ha}^{-1}$. No tratamento $\mathrm{L}_{125}$ a EUA observa foi de 16,6 $\mathrm{kg} \mathrm{MS} \mathrm{mm}^{-1} \mathrm{ha}^{-1}$, da mesma forma que seriam necessários $6.025 \mathrm{~m}^{3}$ ha $^{-1}$ (Tabela 7).

A natureza da resistência de gramíneas forrageiras à seca é complexa e envolve uma série de interações entre planta e ambiente (Klar et al., 1978). Machado et al., (1983) estudando a tolerancia de capim Bufel (Cenchrus ciliaris) e outras gramíneas a seca, observou que a resistência estomática deste capim conduzido sob regime seco não apresentou resistência estomática diferida em relação à testemunha (sem restrição hídrica), o autor comenta ainda que esta característica demonstra a alta adaptabilidade das gramíneas forrageias à deficiência hídrica.

Em condições de baixa disponibilidade de água no solo, as plantas utilizam diferentes mecanismos de ajuste, visando diminuir o consumo de água, para transpor o período adverso. O sistema radicular do capim Tanzânia é amplo e altamente adaptável (Pagoto, 2001), sendo um mecanismo fisiológico importante, ajudando a planta a atravessar períodos secos, sem sofrer danos visíveis (Kramer, 1969).

Segundo Rodrigues \& Rodrigues (1987) a importância da deficiência hídrica pode ser avaliada através do primeiro sintoma observado nas plantas, que seria a redução da taxa de alongamento foliar, que é um parâmetro fisiológico mais sensível à falta de água e, com a perda de turgor das células foliares tem-se imediata interrupção do processo de elongação, redução da fotossíntese, diminuição na área foliar e absorção de nutrientes.

A eficiência no uso de água é dada pela relação entre a produção de forragem e a quantidade de água utilizada. No caso da alfafa, para produção de feno com 10 a $15 \%$ de umidade, a eficiência de utilização é de 1,5 a $2,0 \mathrm{~kg}$ de $\mathrm{feno} / \mathrm{m}^{3}$ de água evapotranspirada depois do primeiro ano (Doorembos e Kassan, 1979). 
ABDUL-JABBAR (1983) constatou, em estudos de campo, que a produção de feno de alfafa foi sempre linearmente relacionada com a evapotranspiração e que a eficiência de uso da água não diferiu entre os cultivares testados, bem como com relação à resposta de rendimento à disponbilidade hídrica. Além disso, Paspecu e Gafiteanu (1990) verificaram que as diferenças são mínimas entre a eficiência no uso da água de cultivares irrigados e não irrigados.

Com base nos resultados obtidos e experiências vivenciadas na condução do experimento e com o propósito de contribuir para trabalhos futuros, algumas sugestões são apresentadas:

a) Observou-se que a evapotranspiração do capim Tanzânia aumenta em função da produtividade, desta forma, o controle da lâmina de referência por dose de adubação apresentaria uma precisão maior no controle da disponibilidade hídrica por tratamento.

b) Nos tratamentos com lâmina de irrigação reduzidas 25, 50 e 75\% da ET a extração da adubação nitrogenada provavelmente foi menor em relação aos tratamentos sem deficiência hídrica (100 e 125\%) onde observou-se maiores produções. Em condições de campo, uma possível explicação sobre o destino do N aplicado poderia auxiliar na tomada de decisão do produtor sobre parcelamentos da adubação nitrogenada para evitar perdas de adubo e contaminação do meio ambiente.

c) Devido as condições do experimento, não foi possível a avaliação da produção de forragem do capim Tanzânia em condições de temperatura média ao longo do ciclo de crescimento superior a $24{ }^{\circ} \mathrm{C}$, sendo que, em condições de maior temperatura a resposta da cultura em relação a deficiência hídrica e adubação nitrogenada pode ser superior, sendo uma justificativa para a utilização destas técnicas com maior freqüência nas regiões Centro-Oeste, Norte e Nordeste do Brasil. 
Tabela 9 - Média das EUA determinadas para diferentes lâminas de irrigação, em capim Tanzânia, durante o período experimental

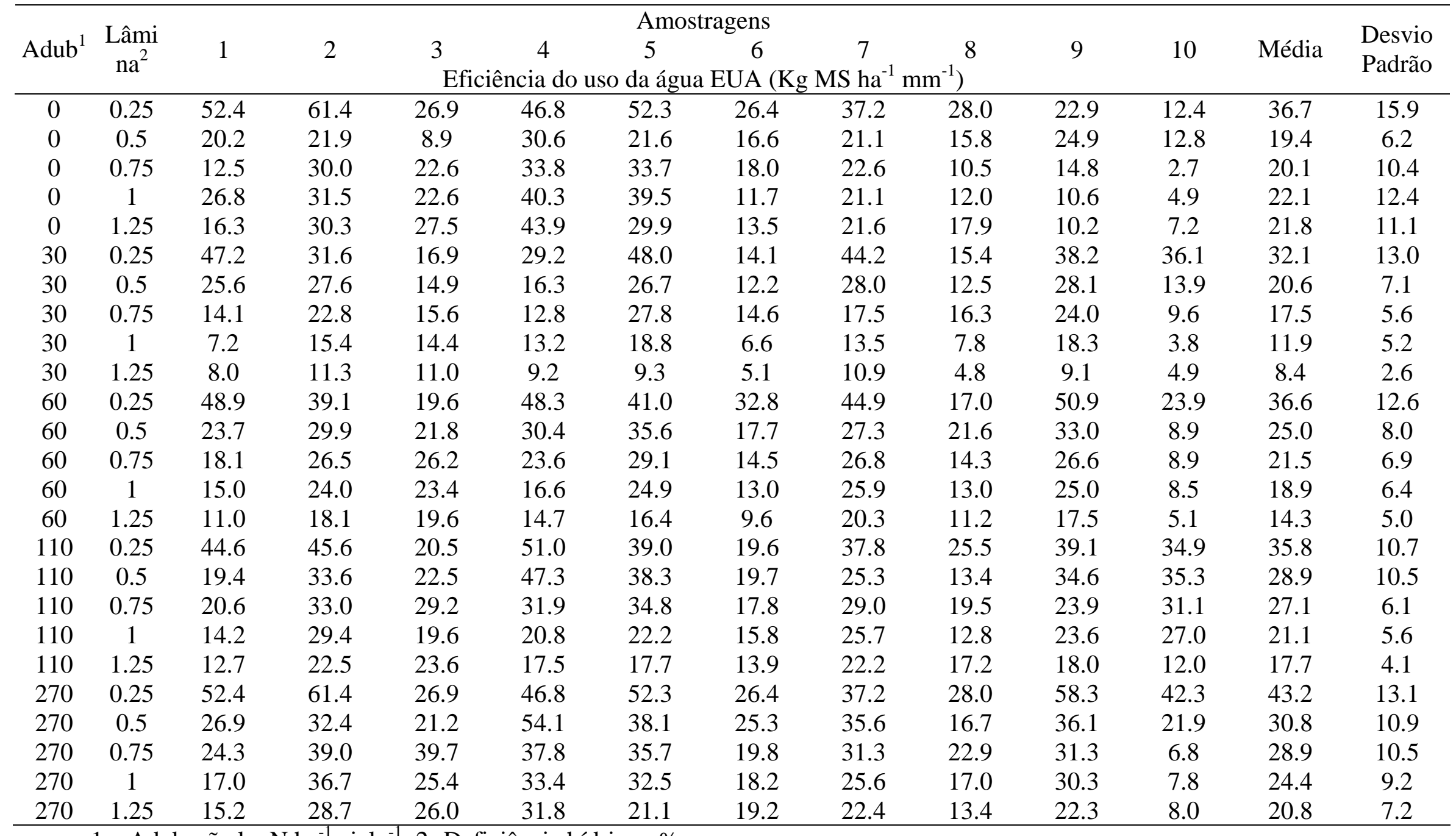

1- Adubação kg N ha ${ }^{-1}$ ciclo $^{-1}$; 2- Deficiência hídrica - \% 


\section{CONCLUSÕES}

Nas condições em que foi realizado o experimento, conclui-se que:

a) Para níveis equivalentes de adubação nitrogenada não ocorre diferença significativa na produção de forragem de capim Tanzânia, quando considerado a estacionalidade de produção em função dos níveis de irrigação.

b) A adubação nitrogenada em altas dosagens no período de inverno, não demonstrou resposta significativa de produtividade mesmo com a eliminação do déficit hídrico no solo (irrigação).

c) A estacionalidade de produção do capim Tanzânia (verão/inverno) foi praticamente equivalente (65/35\%) nos tratamentos intermediários de irrigação avaliados (50, 75 e 100\%). Para os tratamentos extremos de irrigação 25 e 125\%, a estacionalidade de produção aumentou: 67/33 e 75/25\%, respectivamente.

d) O capim Tanzânia apresenta eficientes mecanismos de resistência a seca, porém, quanto maior o nível da adubação nitrogenado, mais significativa é o efeito da deficiência hídrica na produtividade do capim Tanzânia.

e) O coeficiente de resposta da cultura à deficiência hídrica - Ky variou entre 0,75 e 0,80 . 
f) A eficiência de utilização da água do capim Tanzânia foi de 36,0 e 16,6 kg MS $\mathrm{mm}^{-1} \mathrm{ha}^{-1}$ respectivamente para os tratamentos L25 e L125.

g) Água e nitrogênio são elementos importantes para o incremento da produção de forragem no capim Tanzânia, porém, a temperatura média ao longo do ciclo é uma variável limitante ao sistema, desta forma, em regiões onde as temperaturas ao longo do ano são mais elevadas que em Piracicaba - SP, existirá maior probabilidade de eficiência da adubação nitrogenada e da irrigação na produção de forragem do capim Tanzânia. 
A N E X O 
Anexo A. Dados de produção de forragem do capim Tanzânia nos 10 ciclos de corte nos 5 blocos

\begin{tabular}{|c|c|c|c|c|c|c|c|c|c|c|c|c|c|c|}
\hline Caixa & BL & AD & $\mathbf{L}$ & 1 & 2 & 3 & 4 & 5 & 6 & 7 & 8 & 9 & 10 & Total \\
\hline 23 & 1 & 0 & 0.25 & 2.48 & 0.92 & 0.10 & 0.70 & 1.91 & 0.19 & 0.72 & 0.25 & 0.59 & 0.39 & 8.25 \\
\hline 47 & 2 & 0 & 0.25 & 2.12 & 1.80 & 0.57 & 1.82 & 1.36 & 0.41 & 0.75 & 0.86 & 0.48 & 0.81 & 11.00 \\
\hline 72 & 3 & 0 & 0.25 & 1.72 & 1.36 & 0.51 & 0.62 & 0.64 & 0.04 & 0.54 & 0.08 & 0.58 & 0.25 & 6.34 \\
\hline 84 & 4 & 0 & 0.25 & 2.41 & 1.23 & 0.77 & 1.09 & 0.49 & 0.39 & 0.64 & 0.43 & 0.58 & 0.62 & 8.65 \\
\hline 10 & 1 & 30 & 0.25 & 2.80 & 1.98 & 0.84 & 1.96 & 0.64 & 0.65 & 0.70 & 0.50 & 1.45 & 1.14 & 12.67 \\
\hline 44 & 2 & 30 & 0.25 & 2.13 & 1.51 & 0.40 & 1.96 & 1.29 & 0.71 & 0.80 & 0.45 & 1.70 & 1.15 & 12.09 \\
\hline 54 & 3 & 30 & 0.25 & 1.92 & 1.63 & 0.14 & 1.00 & 0.84 & 0.40 & 0.43 & 0.22 & 0.83 & 0.88 & 8.30 \\
\hline 89 & 4 & 30 & 0.25 & 2.21 & 1.44 & 0.89 & 2.08 & 1.00 & 0.63 & 0.76 & 0.61 & 0.86 & 0.92 & 11.40 \\
\hline 21 & 1 & 60 & 0.25 & 2.38 & 2.21 & 0.65 & 1.06 & 1.40 & 0.16 & 0.51 & 1.12 & 0.47 & 0.49 & 10.45 \\
\hline 50 & 2 & 60 & 0.25 & 2.72 & 1.92 & 0.90 & 2.65 & 0.51 & 0.51 & 0.84 & 0.60 & 1.87 & 0.77 & 13.30 \\
\hline 74 & 3 & 60 & 0.25 & 1.64 & 1.17 & 0.43 & 1.62 & 0.52 & 0.49 & 0.53 & 0.52 & 0.88 & 0.76 & 8.56 \\
\hline 77 & 4 & 60 & 0.25 & 1.52 & 2.36 & 0.39 & 2.06 & 1.16 & 0.26 & 0.39 & 0.45 & 1.09 & 0.56 & 10.23 \\
\hline 11 & 1 & 110 & 0.25 & 3.01 & 1.74 & 0.52 & 1.82 & 1.67 & 0.27 & 0.39 & 0.82 & 0.83 & 0.85 & 11.92 \\
\hline 30 & 2 & 110 & 0.25 & 2.79 & 3.70 & 0.50 & 1.27 & 1.49 & 0.65 & 0.76 & 0.60 & 1.23 & 1.07 & 14.06 \\
\hline 57 & 3 & 110 & 0.25 & 1.55 & 1.40 & 0.82 & 1.56 & 0.44 & 0.20 & 0.37 & 0.60 & 0.71 & 0.80 & 8.45 \\
\hline 98 & 4 & 110 & 0.25 & 2.35 & 3.49 & 1.29 & 2.13 & 1.22 & 0.81 & 0.71 & 0.91 & 1.34 & 1.11 & 15.35 \\
\hline 13 & 1 & 270 & 0.25 & 1.03 & 1.69 & 0.28 & 1.76 & 0.85 & 0.41 & 0.62 & 0.22 & 0.97 & 2.24 & 10.07 \\
\hline 38 & 2 & 270 & 0.25 & 2.20 & 2.01 & 0.95 & 2.68 & 1.71 & 0.52 & 0.80 & 1.23 & 0.96 & 2.97 & 16.04 \\
\hline 60 & 3 & 270 & 0.25 & 1.55 & 1.57 & 0.36 & 1.81 & 0.63 & 1.02 & 0.72 & 1.25 & 1.85 & 3.43 & 14.20 \\
\hline 78 & 4 & 270 & 0.25 & 2.67 & 2.08 & 0.48 & 2.63 & 0.79 & 0.47 & 0.39 & 0.61 & 1.20 & 1.90 & 13.23 \\
\hline 14 & 1 & 0 & 0.5 & 2.81 & 2.84 & 0.61 & 1.33 & 1.08 & 0.43 & 0.68 & 0.46 & 0.95 & 1.34 & 12.53 \\
\hline 40 & 2 & 0 & 0.5 & 1.88 & 1.93 & 1.00 & 1.35 & 1.20 & 0.51 & 0.84 & 0.80 & 0.89 & 1.39 & 11.79 \\
\hline 69 & 3 & 0 & 0.5 & 2.08 & 1.51 & 0.60 & 0.92 & 0.85 & 0.30 & 0.93 & 0.43 & 0.76 & 0.65 & 9.03 \\
\hline 88 & 4 & 0 & 0.5 & 2.68 & 2.98 & 1.25 & 1.13 & 1.77 & 0.54 & 0.91 & 0.94 & 1.11 & 0.99 & 14.32 \\
\hline 4 & 1 & 30 & 0.5 & 1.56 & 2.04 & 1.42 & 2.39 & 1.79 & 0.69 & 0.51 & 0.71 & 1.71 & 1.27 & 14.08 \\
\hline 41 & 2 & 30 & 0.5 & 2.40 & 3.11 & 1.14 & 1.99 & 1.93 & 0.88 & 1.08 & 2.38 & 1.54 & 2.03 & 18.49 \\
\hline 65 & 3 & 30 & 0.5 & 2.03 & 2.59 & 1.01 & 1.62 & 0.81 & 0.60 & 0.94 & 0.58 & 1.27 & 1.40 & 12.87 \\
\hline 95 & 4 & 30 & 0.5 & 2.76 & 2.32 & 1.48 & 2.83 & 2.01 & 0.41 & 0.74 & 0.88 & 0.93 & 1.57 & 15.93 \\
\hline 17 & 1 & 60 & 0.5 & 2.24 & 3.51 & 0.88 & 3.23 & 1.47 & 0.60 & 0.41 & 0.35 & 1.54 & 1.14 & 15.36 \\
\hline 45 & 2 & 60 & 0.5 & 1.41 & 2.83 & 1.05 & 3.80 & 2.41 & 0.71 & 0.60 & 0.51 & 1.88 & 1.68 & 16.88 \\
\hline 59 & 3 & 60 & 0.5 & 1.45 & 2.56 & 1.62 & 2.70 & 1.53 & 0.85 & 1.20 & 0.69 & 2.26 & 1.78 & 16.64 \\
\hline 82 & 4 & 60 & 0.5 & 2.08 & 2.38 & 1.66 & 3.99 & 1.63 & 0.71 & 0.83 & 1.27 & 1.31 & 1.74 & 17.62 \\
\hline 18 & 1 & 110 & 0.5 & 1.60 & 3.96 & 1.14 & 4.40 & 2.52 & 1.15 & 1.43 & 0.65 & 1.86 & 1.63 & 20.34 \\
\hline 39 & 2 & 110 & 0.5 & 2.79 & 2.56 & 1.09 & 3.95 & 1.48 & 1.11 & 1.45 & 0.91 & 2.21 & 1.89 & 19.44 \\
\hline 51 & 3 & 110 & 0.5 & 2.50 & 2.09 & 1.20 & 2.82 & 1.18 & 0.70 & 0.53 & 0.60 & 1.33 & 1.95 & 14.91 \\
\hline 87 & 4 & 110 & 0.5 & 3.06 & 2.25 & 1.49 & 4.51 & 1.82 & 0.74 & 0.85 & 1.35 & 1.71 & 1.78 & 19.56 \\
\hline 1 & 1 & 270 & 0.5 & 1.55 & 4.20 & 1.81 & 3.03 & 1.89 & 0.93 & 0.59 & 0.53 & 0.79 & 1.49 & 16.80 \\
\hline 32 & 2 & 270 & 0.5 & 2.27 & 4.69 & 1.84 & 4.74 & 2.93 & 1.10 & 1.84 & 1.19 & 0.82 & 1.36 & 22.78 \\
\hline 55 & 3 & 270 & 0.5 & 1.37 & 2.83 & 2.62 & 2.96 & 2.14 & 0.95 & 1.10 & 0.97 & 1.24 & 2.09 & 18.27 \\
\hline 83 & 4 & 270 & 0.5 & 1.73 & 3.42 & 1.60 & 3.97 & 2.35 & 0.95 & 0.54 & 0.62 & 1.58 & 1.58 & 18.36 \\
\hline 12 & 1 & 0 & 0.75 & 2.80 & 2.88 & 1.77 & 1.66 & 1.27 & 0.61 & 0.67 & 1.59 & 0.84 & 0.79 & 14.88 \\
\hline 31 & 2 & 0 & 0.75 & 1.49 & 3.99 & 1.29 & 1.06 & 2.39 & 0.91 & 0.78 & 0.56 & 1.41 & 0.83 & 14.71 \\
\hline 73 & 3 & 0 & 0.75 & 2.26 & 2.40 & 1.61 & 1.87 & 2.01 & 0.67 & 0.86 & 1.77 & 1.27 & 2.62 & 17.34 \\
\hline 97 & 4 & 0 & 0.75 & 1.26 & 2.22 & 0.76 & 0.99 & 2.00 & 1.01 & 0.85 & 1.20 & 1.41 & 1.59 & 13.29 \\
\hline 25 & 1 & 30 & 0.75 & 2.51 & 2.88 & 1.76 & 2.42 & 2.81 & 0.99 & 1.58 & 0.93 & 1.47 & 1.64 & 18.98 \\
\hline
\end{tabular}


Anexo A. Dados de produção de forragem do capim Tanzânia nos 10 ciclos de corte nos 5 bloco

\begin{tabular}{|c|c|c|c|c|c|c|c|c|c|c|c|c|c|c|}
\hline Caixa & BL & AD & $\mathbf{L}$ & 1 & 2 & 3 & 4 & 5 & 6 & 7 & 8 & 9 & 10 & Total \\
\hline 26 & 2 & 30 & 0.75 & 2.23 & 3.31 & 2.91 & 2.54 & 2.16 & 1.02 & 1.05 & 0.92 & 2.48 & 1.71 & 20.33 \\
\hline 62 & 3 & 30 & 0.75 & 3.02 & 2.80 & 2.52 & 2.83 & 1.02 & 0.52 & 1.22 & 1.59 & 1.10 & 2.09 & 18.70 \\
\hline 92 & 4 & 30 & 0.75 & 2.31 & 4.39 & 1.93 & 2.48 & 2.03 & 0.64 & 0.98 & 1.07 & 1.35 & 1.49 & 18.69 \\
\hline 5 & 1 & 60 & 0.75 & 1.88 & 4.41 & 1.90 & 3.28 & 3.72 & 0.80 & 0.28 & 1.20 & 1.95 & 2.20 & 21.63 \\
\hline 33 & 2 & 60 & 0.75 & 2.57 & 4.95 & 1.85 & 3.27 & 1.15 & 1.26 & 1.46 & 2.13 & 2.12 & 4.30 & 25.08 \\
\hline 61 & 3 & 60 & 0.75 & 3.64 & 3.12 & 3.35 & 2.76 & 1.40 & 0.94 & 0.76 & 1.68 & 1.84 & 2.95 & 22.44 \\
\hline 91 & 4 & 60 & 0.75 & 3.33 & 4.18 & 3.04 & 4.55 & 3.32 & 0.89 & 2.71 & 1.15 & 1.82 & 3.07 & 28.07 \\
\hline 20 & 1 & 110 & 0.75 & 3.00 & 3.91 & 2.76 & 4.44 & 2.00 & 1.01 & 1.40 & 1.60 & 1.82 & 3.06 & 25.00 \\
\hline 46 & 2 & 110 & 0.75 & 3.94 & 4.26 & 3.62 & 3.79 & 1.60 & 1.18 & 2.25 & 1.86 & 2.78 & 4.24 & 29.50 \\
\hline 66 & 3 & 110 & 0.75 & 4.32 & 5.51 & 3.78 & 3.38 & 1.88 & 0.92 & 1.01 & 2.14 & 2.63 & 3.51 & 29.08 \\
\hline 100 & 4 & 110 & 0.75 & 2.24 & 5.99 & 3.66 & 4.84 & 4.38 & 1.24 & 0.99 & 1.59 & 2.48 & 3.58 & 30.98 \\
\hline 7 & 1 & 270 & 0.75 & 4.08 & 5.57 & 2.34 & 5.39 & 4.17 & 0.92 & 1.63 & 1.13 & 1.98 & 3.02 & 30.21 \\
\hline 35 & 2 & 270 & 0.75 & 5.21 & 5.97 & 3.37 & 5.97 & 3.72 & 0.81 & 1.22 & 1.57 & 2.15 & 5.53 & 35.50 \\
\hline 68 & 3 & 270 & 0.75 & 4.88 & 5.39 & 2.31 & 6.35 & 3.12 & 0.82 & 1.03 & 0.64 & 2.30 & 3.21 & 30.05 \\
\hline 80 & 4 & 270 & 0.75 & 5.70 & 4.22 & 2.46 & 5.64 & 3.54 & 0.87 & 1.18 & 1.70 & 2.05 & 2.61 & 29.97 \\
\hline 2 & 1 & 0 & 1 & 1.03 & 1.75 & 1.48 & 2.00 & 1.24 & 0.45 & 0.67 & 0.44 & 1.10 & 0.86 & 11.02 \\
\hline 43 & 2 & 0 & 1 & 0.93 & 1.96 & 1.73 & 1.87 & 2.39 & 0.43 & 0.83 & 0.51 & 0.74 & 1.22 & 12.60 \\
\hline 70 & 3 & 0 & 1 & 1.36 & 2.74 & 1.81 & 1.48 & 1.58 & 0.55 & 0.88 & 0.99 & 1.18 & 1.42 & 13.98 \\
\hline 93 & 4 & 0 & 1 & 1.98 & 3.92 & 1.65 & 2.30 & 1.70 & 0.49 & 0.87 & 1.36 & 0.77 & 1.22 & 16.26 \\
\hline 19 & 1 & 30 & 1 & 2.84 & 5.73 & 2.11 & 2.91 & 2.90 & 1.05 & 1.82 & 1.12 & 1.77 & 1.72 & 23.97 \\
\hline 37 & 2 & 30 & 1 & 3.05 & 3.36 & 3.70 & 1.73 & 2.21 & 1.13 & 2.30 & 2.18 & 1.51 & 1.85 & 23.02 \\
\hline 71 & 3 & 30 & 1 & 2.54 & 3.54 & 2.60 & 2.26 & 2.10 & 0.61 & 1.03 & 1.22 & 1.62 & 2.02 & 19.52 \\
\hline 76 & 4 & 30 & 1 & 2.67 & 3.48 & 2.44 & 2.75 & 1.95 & 1.00 & 1.05 & 0.95 & 1.82 & 2.37 & 20.49 \\
\hline 24 & 1 & 60 & 1 & 2.94 & 4.92 & 2.05 & 4.36 & 2.11 & 1.01 & 2.09 & 1.13 & 2.35 & 2.20 & 25.17 \\
\hline 48 & 2 & 60 & 1 & 3.41 & 4.33 & 2.51 & 2.79 & 1.88 & 1.19 & 1.58 & 1.81 & 1.31 & 2.86 & 23.68 \\
\hline 52 & 3 & 60 & 1 & 2.66 & 4.04 & 2.77 & 3.19 & 2.23 & 1.00 & 0.94 & 1.73 & 1.93 & 2.44 & 22.93 \\
\hline 96 & 4 & 60 & 1 & 1.52 & 6.50 & 1.75 & 1.74 & 1.93 & 1.40 & 1.56 & 0.70 & 1.36 & 2.39 & 20.85 \\
\hline 8 & 1 & 110 & 1 & 2.10 & 7.48 & 2.45 & 4.64 & 2.49 & 1.73 & 1.45 & 1.15 & 2.80 & 3.90 & 30.18 \\
\hline 29 & 2 & 110 & 1 & 3.30 & 6.65 & 2.71 & 4.26 & 2.91 & 1.35 & 1.83 & 1.35 & 2.18 & 4.08 & 30.61 \\
\hline 58 & 3 & 110 & 1 & 3.56 & 4.76 & 2.94 & 5.03 & 2.72 & 1.14 & 1.24 & 2.49 & 1.81 & 3.72 & 29.39 \\
\hline 81 & 4 & 110 & 1 & 3.62 & 5.80 & 3.67 & 5.46 & 3.85 & 1.11 & 1.62 & 2.17 & 2.39 & 4.58 & 34.26 \\
\hline 6 & 1 & 270 & 1 & 4.34 & 6.65 & 3.08 & 7.07 & 2.50 & 1.09 & 1.47 & 2.48 & 2.53 & 4.06 & 35.27 \\
\hline 28 & 2 & 270 & 1 & 3.82 & 6.31 & 4.09 & 7.01 & 3.98 & 1.30 & 2.04 & 3.09 & 1.71 & 3.72 & 37.07 \\
\hline 63 & 3 & 270 & 1 & 3.66 & 6.33 & 3.60 & 8.49 & 3.31 & 1.19 & 1.43 & 1.37 & 2.12 & 4.41 & 35.91 \\
\hline 90 & 4 & 270 & 1 & 3.25 & 6.17 & 5.15 & 9.23 & 3.96 & 1.34 & 1.52 & 2.47 & 2.37 & 6.50 & 41.97 \\
\hline 3 & 1 & 0 & 1.25 & 0.98 & 1.57 & 1.16 & 1.76 & 1.42 & 0.31 & 0.74 & 0.21 & 2.04 & 1.02 & 11.21 \\
\hline 34 & 2 & 0 & 1.25 & 2.45 & 3.76 & 1.76 & 2.27 & 1.31 & 0.78 & 0.67 & 0.74 & 1.18 & 1.17 & 16.08 \\
\hline 75 & 3 & 0 & 1.25 & 1.34 & 2.47 & 1.72 & 1.34 & 0.76 & 0.29 & 1.12 & 0.88 & 1.60 & 1.33 & 12.86 \\
\hline 94 & 4 & 0 & 1.25 & 2.60 & 1.68 & 1.74 & 1.31 & 0.77 & 0.48 & 0.75 & 0.69 & 0.85 & 1.02 & 11.89 \\
\hline 16 & 1 & 30 & 1.25 & 1.71 & 4.26 & 3.46 & 3.08 & 2.49 & 0.80 & 2.07 & 2.12 & 1.76 & 1.72 & 23.46 \\
\hline 27 & 2 & 30 & 1.25 & 1.87 & 4.58 & 2.65 & 2.61 & 1.43 & 1.03 & 1.66 & 1.25 & 1.42 & 2.04 & 20.55 \\
\hline 53 & 3 & 30 & 1.25 & 2.70 & 2.93 & 2.44 & 2.68 & 1.54 & 0.62 & 1.37 & 0.82 & 1.70 & 2.27 & 19.06 \\
\hline 99 & 4 & 30 & 1.25 & 3.87 & 3.42 & 2.83 & 2.27 & 2.10 & 1.05 & 0.97 & 1.69 & 2.12 & 2.18 & 22.50 \\
\hline 22 & 1 & 60 & 1.25 & 2.34 & 4.72 & 2.72 & 2.65 & 1.46 & 0.93 & 1.23 & 3.44 & 1.82 & 2.55 & 23.87 \\
\hline 42 & 2 & 60 & 1.25 & 3.41 & 4.58 & 3.89 & 3.44 & 1.58 & 1.35 & 2.57 & 1.88 & 2.76 & 3.75 & 29.21 \\
\hline
\end{tabular}


Anexo A. Dados de produção de forragem do capim Tanzânia nos 10 ciclos de corte nos 5 bloco

\begin{tabular}{ccccccccccccccc}
\hline Caixa & BL & AD & $\mathbf{L}$ & $\mathbf{1}$ & $\mathbf{2}$ & $\mathbf{3}$ & $\mathbf{4}$ & $\mathbf{5}$ & $\mathbf{6}$ & $\mathbf{7}$ & $\mathbf{8}$ & $\mathbf{9}$ & $\mathbf{1 0}$ & Total \\
\hline 64 & 3 & 60 & 1.25 & 2.75 & 5.01 & 2.73 & 3.14 & 2.40 & 1.50 & 1.74 & 1.32 & 2.52 & 2.59 & 25.71 \\
85 & 4 & 60 & 1.25 & 3.23 & 4.57 & 4.37 & 3.44 & 2.69 & 1.30 & 1.12 & 2.41 & 2.02 & 4.48 & 29.64 \\
9 & 1 & 110 & 1.25 & 3.15 & 5.82 & 3.33 & 5.24 & 2.09 & 1.80 & 1.62 & 1.63 & 2.71 & 3.16 & 30.54 \\
36 & 2 & 110 & 1.25 & 3.04 & 6.00 & 3.45 & 5.26 & 2.21 & 2.19 & 2.23 & 1.63 & 3.52 & 4.36 & 33.90 \\
67 & 3 & 110 & 1.25 & 3.65 & 6.05 & 3.72 & 6.92 & 2.29 & 1.28 & 1.46 & 1.52 & 3.20 & 4.24 & 34.33 \\
86 & 4 & 110 & 1.25 & 4.22 & 6.21 & 4.55 & 5.65 & 3.10 & 1.73 & 1.41 & 2.25 & 2.31 & 4.78 & 36.21 \\
15 & 1 & 270 & 1.25 & 3.71 & 5.46 & 4.11 & 8.49 & 2.14 & 1.34 & 1.83 & 1.81 & 2.80 & 4.34 & 36.02 \\
49 & 2 & 270 & 1.25 & 4.82 & 6.76 & 4.10 & 8.16 & 2.16 & 1.22 & 1.41 & 1.80 & 2.47 & 4.52 & 37.43 \\
56 & 3 & 270 & 1.25 & 6.41 & 6.16 & 4.86 & 9.35 & 2.07 & 1.28 & 1.52 & 1.63 & 2.66 & 4.43 & 40.39 \\
79 & 4 & 270 & 1.25 & 5.38 & 6.08 & 4.72 & 8.25 & 2.82 & 1.48 & 1.85 & 1.92 & 2.86 & 4.22 & 39.59 \\
\hline
\end{tabular}




\section{REFERÊNCIAS BIBLIOGRÁFICAS}

ABDUL-JABBAR, A.S. Alfafa water use and growth under a gradient irrigation system. Dissertação Abstract International. v.44, n.3, p. 661., 1983.

ARONOVICH, S. O capim colonião e outros cultivares de Panicum maximum jacq.: Introdução e evolução do uso no Brasil. In: SIMPÓSIO SOBRE MANEJO DA PASTAGEM. 12., Piracicaba, 1995.Anais. Piracicaba: FEALQ, 1995. p.1-20.

ANUALPEC 2001 - Anuário estatístico da Produção animal, 2001, Editora Argos Comunicação, São Paulo, 359 p.

ALVIN, M.J.; BOTREL, M. A. de; NOVELLY, P. E. Produção de gramíneas tropicais e temperadas irrigadas na época da seca. Revista da Sociedade Brasileira de Zootecnia, Viçosa, v.15, n.5, p. 384-392, 1986.

BARIONI, L.G. Modelagem dinâmica e otimização metaheurística para apoio à tomada de decisões na recria e engorda de bovinos de corte. Piracicaba, 2002. 100 p. Tese (Doutorado) - Escola Superior de Agricultura “Luiz de Queiroz”, Universidade de São Paulo.

BALSALOBRE, M.A.A. SANTOS, P.M.; BARROS, A.L.M. Inovações tecnológicas, investimentos financeiros e gestão de sistema de produção animal em pastagens. In: SIMPÓSIO SOBRE MANEJO DA PASTAGEM, 19., Piracicaba, 2002. Anais. Piracicaba : FEALQ, 2002. p.1-30. 
BEGG, J.; TURnER, N. Crop water deficits. Advanced Agronomie., v.28, p.161-207, 1976.

BOTREL, M. de A.; ALVIM, M.J.; XAVIER, D.F. Efeito da irrigação sobre algumas características agronômicas de cultivares de capim Elefante. Pesquisa Agropecuária Brasileira, v.26, n. 10, p.1731-1736, 1991.

CECATO, U.; MARCO, A.A.F.B.; SAKAGUTI, E.S.; DAMASCENO, J.C.; SUZUKI, E.; MEURER, F. Avaliação de cultivares de Panicum maximum Jacq. In: REUNIÃO ANUAL DA SOCIEDADE BRASILEIRA DE ZOOTECNIA, 34., Fortaleza, 1996. Anais. Fortaleza: SBZ, 1996. p.403-406.

DIAS, P.F.; ROCHA. G.P.; OLIVEIRA, A.I.G.; PINTO, J..; ROCHA FILHO, R.R.; SOUTO, S.M. Produtividade e qualidade de gramíneas forrageiras tropicais sob adubação nitrogenada no final do período das águas. Pesquisa Agropecuária Brasileira,v.3, n.7, p.1191-1197, 1998.

DOOREMBOS, J.; KASSAN, A.H. Efectos del água sobre el rendimientos de los cultivos. Roma: FAO, 1979. 212p. (Riego y Drenage, 33).

DOURADO-NETO, D. FANCELLI, A.L.; MULLER, M.S. Manejo da irrigação em pastagens. In: SIMPÓSIO SOBRE MANEJO DA PASTAGEM, 19. Piracicaba, 2002. Anais. Piracicaba : FEALQ, 2002. p.189-216.

EUCLIDES, V.P.B.; MACEDO, M.C.M.; OLIVEIRA, M.P. Animal production in tropical pastures recovered by subsoiling and fertilization in the Cerrados of Brazil. In: INTERNATIONAL GRASSLAND CONGRESS, 19., São Pedro, 2001. Proceedings. São Pedro: FEALQ, 2001. p.841-842. 
FAGUNDES, J.L.; DA SILVA, S.C.; PEDREIRA, C.G.S., SBRISSIA, A.F.; CARNEVALLI, R.A., CARVALHO, C.A.B. PINTO, L.F.M. Índice de área foliar, interceptação luminosa e acúmulo de forragem em pastagens de Cynodon spp. sob diferentes intensidade de pastejo. Scientia Agrícola, v.56,n.4,p.1141-1150, 1999.

FORNI, S. MICHEL FILHO, L.C.; FAVORETTO, V.; MALHEIROS, E.B. Efeito de estratégias de adubação NPK sobre a produção, qualidade e estrutura das cultivares Tanzânia e Mombaça de Panicum maximum Jacq.. In: REUNIÃO ANUAL DA SOCIEDADE BRASILEIRA DE ZOOTECNIA, 37., Voçosa, 2000. Anais. Voçosa: SBZ, 2000. http://www.sbz.org.br/anais2000/Forragem/702.pdf . (15 dez. 2003).

CANTARELlA, H.; CORRÊA, L. de A. PRIMAVESI, O.;PRIMAVESI, A.C. Fertilidade do solo em sistemas intensivos de manejo de pastagens. SIMPÓSIO SOBRE MANEJO DA PASTAGEM 19², Piracicaba, 2002 Inovações tecnológicas no manejo de pastagens, anais. Piracicaba:FEALQ, 2002. 231.

CARVALHO, M.M., MARTINS, C.E., VERNEQUE, R. da S. et al. Resposta de uma espécie de braquiária à fertilização com nitrogênio e potássio em um solo ácido. Revista da Sociedade Brasileira de Zootecnia. v. 13, n. 2, p.243-253, 1988.

COOPER, J.P.; TAINTON, N.M. Light and temperature requirements for the growth of tropical and temperate grasses. Herbage Abstracts,v.38, p.167-176, 1968.

CORSI, M. Effects of nitrogen rates and harvesting intervals on dry matter productivity, tillering and quality of the tropical grass Panicum maximun (Jacq.). Ohio, EUA, 1984, 125 p. Tese (PhD.) - Ohio State University.

CORSI, M. Pastagem de alta produtvidade. In: SIMPÓSIO SOBRE MANEJO DE PASTAGENS, 8. Piracicaba, 1986. Anais. Piracicaba: FEALQ, 1986, p.499-512. 
CORSI, M. Manejo de plantas forrageiras do gênero Panicum. In: SIMPÓSIO SOBRE MANEJO DA PASTAGEM. 9., Piracicaba, 1988.Anais. Piracicaba: FEALQ, 1988. p.57-77.

CORSI, M.; NASCIMENTO JÚNIOR, D. Princípios de fisiologia e morfologia de plantas forrageiras aplicados no manejo das pastagens. In: Pastagens: fundamentos da exploração racional. PEIXOTO et al. (Ed.) Piracicaba: FEALQ, 1994,p.15-47.

CORSI, M.; MARTHA JÚNIOR, G.B. Manutenção da fertilidade do solo em sistemas intensivos de pastejo rotacionado. In: SIMPÓSIO SOBRE MANEJO DA PASTAGEM. 15., Piracicaba, 1998b.Anais. Piracicaba: FEALQ, 1998. p.55-83.

CORSI, M.; NUSSIO, L.G. Manejo do capim elefante: correção e adubação do solo. In: SIMPÓSIO SOBRE MANEJO DA PASTAGEM. 10., Piracicaba, 1993.Anais. Piracicaba: FEALQ, 1988b. p.87-116.

COSSA, C.A.; PEDRAS, J.F. Efeitos de três potenciais de água na produção de Medicago sativa, l. In: REUNIÃO ANUAL DA SOCIEDADE BRASILEIRA DE ZOOTECNIA, 34, Juiz de Fora, MG, 1987. Anais. Juis de Fora: SBZ, 1997, p. 122123.

CUNHA, G.R. Evapotranspiração e função de resposta à disponibilidade hídrica da alfafa. , Porto Alegre, RS, 1991, 197 p. Tese (Doutorado) - Universidade Federal do Rio Grande do Sul.

DAVIES, D.A.; FURTHERGILL, M.; MORGAN, C.T. Assessment of contrasting perennial ryegrasses and white clover under continuous stocking in the uplands. 5. Herbage production quality and intake in years 4-6. Grass and Forage Science, v.48, n.3, p. 213-222, 1993. 
DIAS FILHO, M.B., CORSI, M. CUSATO, S. Respostas morfológicas e Panicum maxumun jacq. cv. Tobiatã ao estresse hídrico. Pesquisa Agropecuária Brasileira, v.24, n.7, p. 893-898, jul. 1989.

FAGUNDES, J.L. Efeito de intensidade de pastejo sobre o índice de área foliar, interceptação luminosa e acúmulo de forragem em pastagens de cynodom spp. Piracicaba, 1999. 69p. Dissertação (Mestrado) - Escola Superior de Agricultura “Luiz de Queiroz”, Universidade de São Paulo.

FRANKE, A.E.; DORFMAN, R. Viabilidade econômica da irrigação, sob condições de risco, em regiões de clima tropical. Pesquisa Agropecuária Brasileira, v. 33, n. 12, p. 2003-2013, dez. 1998.

GARABET, S.; WOOD, M.; RYAN, J. Nitrogen and water effects on wheat yield in a Mediterranean-type climate I. Growth, water-use and nitrogen accumulation. Field Crops Research , v. 57, p.309-318, 1998.

GARCIA, J. A. R. Efeito de diferentes lâminas d'água sobre a cultura da aveia irrigada por inundação temporária. Lavras , 1993. 71 p. Dissertação (Mestrado) - Escola Superior de Agricultura de Lavras.

GHELFI FILHO, H. Efeito da irrigação sobre a produtividade do capim Elefante (Pennisetum purpureum Schum) variedade Napier. Piracicaba, 1972. 77p. Dissertação (Doutorado) - Escola Superior de Agricultura "Luiz de Queiroz" , Universidade de São Paulo.

GHELFI FILHO, H . Efeito da irrigação sobre o capim colonião (Panicum maximum Jacq.). O solo, v. 58, n. 1 p.12-16, 1976. 
GOMIDE, C.A. de M.; GOMIDE, J.A. Análise de crescimento de cultivares de Panicum maximum Jacq. Revista Brasileira de Zootecnia., v.28, n. 4, p. 675-680, 1999.

GRANDINI, D. V. Produção de bovinos a pasto com suplementação protéico e/ou energéticos. Sociedade brasileira de zootecnia. Edit. por Wilson Roberto Soares Mattos et al. Piracicaba: FEALQ, p. 235-252, 2001.

HERLING, V.R., ZANETTI, M.A., GOMIDE, C.A. et al. Influência de níveis de adubações nitrogenadas e potássica e estádios de crescimento sobre o capim setária. I. Produção de matéria seca e fisiologia de perfilhamento. Revista da Sociedade Brasileira de Zootecnia. v.20, n. 6, p.561-571, 1991.

JANK, L. Melhoramento e seleção de variedades de Panicum maximum. In: SIMPÓSIO SOBRE MANEJO DA PASTAGEM, 12., Piracicaba, 1995. Anais. Piracicaba: FEALQ, 1995. p.21-58.

JARVIS, S.C.; SCHOLEFIELD, D.; PAIN, B. Nitrogen cycling in grazing systems. In: BACON, P.E. (Ed.). Nitrogen fertilization in the environment. New Yrok: Marcel Dekker, 1995. p.381-419.

KALAPOS, T.; BOOGAARD, R.; LAMBERS, H. Effect of soil drying on growth, biomass allocation and leaf gas exchange or two annual grass species. Plant and Soil, v. 185, p.137-149, 1996.

KLAR, A.E.; USBERTI, J.A.; HENDERSON, D.W. Differential response of Guinea grass populations to drought stress. Croop Science., v. 18, p. 853-857, 1978.

KRAMER, P.J. Plant and soil water relationship: a modern synthesis. New York, McGrow-Hill, 1969. 
LOURENÇO, L. F., COELHO, R. D. SORIA, L.G.T., PINHEIRO, V.D., CORSI, M. Coeficiente de cultura (Kc) do capim tanzânia (Panicum maximum Jacq) irrigado por pivô central. IN: Congresso Brasileiro de Engenharia Agrícola, Foz do Iguaçu, 2001a.

LOURENÇO, L.F.; COELHO, R.D.; SORIA. L.G.T. PINHEIRO, V.D.; CORSI, M. Coeficiente de cultura (Kc) do capim Tanzânia (Panicum maximum Jacq) irrigado por pivô central. In: REUNIÃO ANUAL DA SOCIEDADE BRASILEIRA DE ZOOTECNIA, 38., Piracicaba, 2001. A produção animal na visão dos brasileiros: Anais. Piracicaba: SBZ, 2001b. p.1013-1017.

MACHADO, R.C.R.; SOUZA, H.M.F.; MORENO, M.A.; ALVIM, P. de T. Variáveis relacionadas com a tolerância de gramíneas forrageiras ao déficit hídrico. Pesquisa Agropecuária Brasileira, v. 18 n. 6, p.603-608, 1983.

MARTHA JÚNIOR, G.B. Produção de forragem e transformação do nitrogênio do fertilizante em pastagem irrigada de capim Tanzânia. Piracicaba, 2003. 149p. : il. Tese (Doutorado). Escola Superior de Agricultura “Luiz de Queiroz” - Universidade de São Paulo.

MARTHA JÚNIOR, G.B.; VILELA L. Pastagens no cerrado: baixa produtividade pelo uso limitado de fertilizantes em pastagens. Planaltina: Embrapa Cerrados, 2002. 32p. (Documentos, 50).

MAYA, F.L.A. Produtividade e viabilidade econômica da recria e engorda de bovinos em pastagens adubadas intensivamente com e sem o uso da irrigação. Piracicaba, 2003. 83p. : il. Dissertação (Mestrado). Escola Superior de Agricultura "Luiz de Queiroz” - Universidade de São Paulo. 
MANNETJE, L.t'; PRITCHARD, A.J. The effect os daylenght and temperature on introduced legumes and grasses for topics and subtropics of Coastal Australia. I.Dry matter production, tillering and leaf area. Australian Journal of Experimental Agriculture and Animal Husbandry, v.14,p.173-181, 1974.

McINTYRE, G.A. Statical aspects of vegetation sampling. In: MANNETJE, L. Measurement of grassland vegetation and animal production, $\mathrm{CAB}$ International Bureau of Pasture and Field Crops, Hurley, Berkshire, p. 8-21. 1987.

MELLO, A.C.L. Efeito de três massas de forragem pós pastejo em Panicum maximum Jacq cv Tanzânia sobre a taxa fotossintética, índice de área foliar e ângulo foliar. Piracicaba, 2002. 67p. Tese (Doutorado) - Escola Superior de Agricultura “Luiz de Queiroz”, Universidade de São Paulo.

MONTEIRO, F.A., WERNER, J.C. Efeitos das adubações nitrogenadas e fosfatadas de capim-colonião, na formação e em pasto estabelecido. Boletim da Indústria Animal, v. 34, n. 1 p. 91-101, 1977.

MÜLLER, M. dos S. Desempenho de Panicum maximun (cv. Monbaça) em pastejo rotacionado sob sistema de irrigação por pivô central, na região de cerrado. Piracicaba, 2000. Dissertação (Mestrado). Escola Superior de Agricultura "Luiz de Queiroz” - Universidade de São Paulo.

PAGOTTO, D.S. Comportamento do sistema radicular do capim Tanzânia (Panicum maximun, Jacq.) sob irrigação e submetido a diferentes intensidades de pastejo. Piracicaba, 2001. Dissertação (Mestrado). Escola Superior de Agricultura "Luiz de Queiroz” - Universidade de São Paulo. 
PASPECU, C.; GAFITEANU, D. Water efficiency evaluation in some irrigated crop in Moldavia. Cecetori Agronomie Moldova, v.23, p.21-29, 1990.

PATERNIANI, R.S. Respostas de seis híbridos de capim-colonião (Panicum maximum Jacq.) a níveis de adubação com N, P, K. Piracicaba, 2000. 211p. Teses (Doutorado) - Escola Superior de Agricultura “Luiz de Queiroz”, Universidade de São Paulo.

PAULINO, V.T. Efeito da fertilização fosfatada, da calagem e micronutrientes no desenvolvimento de plantas forrageiras. Piracicaba, 1990. 281 p. Tese (Mestrado) Escola Superior de Agricultura “Luiz de Queiroz”, Universidade de São Paulo.

PARSCH, L.D.; POPPI, M.P.; LOEWER, O.J. Stocking rate risk for pasture-fed steers under weather uncertainty. Journal of Range Management, v.50, p,541-549, 1997.

PINHEIRO, V.D. Viabilidade econômica da irrigação de pastagem de capim Tanzânia em diferentes regiões do Brasil. Piracicaba, 2002. 85 p. Tese (Mestrado) - Escola Superior de Agricultura “Luiz de Queiroz”, Universidade de São Paulo.

PINHEIRO, V.D.; COELHO, R.D.; LOURENÇO, L.F. Viabilidade econômica da irrigação de pastagem de capim Tanzânia em diferentes regiões do Brasil. In: SIMPÓSIO SOBRE MANEJO DA PASTAGEM, 19, Piracicaba, 2002. Anais. Piracicaba : FEALQ, 2002. p.159-188.

PENATI, M.A. Estudo do desempenho animal e produção do capim Tanzânia (Panicum maximun Jacq.) em um sistema rotacionado de pastejo sob irrigação em três níveis de resíduo pós pastejo. Piracicaba, 2002. 117 p. Tese (Doutorado) - Escola Superior de Agricultura “Luiz de Queiroz”, Universidade de São Paulo. 
PENATI, M.A., CORSI, M., DIAS, C.T.S, MAYA, F.L.A. Efeito do número de amostras e da relação dimensão-formato da moldura sobre o coeficiente de variação da determinação de massa de forragem em pastagens de capim Tanzânia. REUNIÃO ANUAL DA SOCIEDADE BRASILEIRA DE ZOOTECNIA 38. Piracicaba, 2001. Anais

PIETERSE, P.A.; RETHMAN, N.F.G.; VAN BOCH, J. Production, water use efficiency and quality of four cultivars of Panicum maximum Jacq. at different levels of nitrogen fertilization. Tropical Grassland, 31:117-123, 1997.

PINHEIRO, V.D. Viabilidade econômica da irrigação em pastagem de capim Tanzânia em diferentes regiões do Brasil. Piracicaba, 2002. Dissertação (Mestrado). Escola Superior de Agricultura “Luiz de Queiroz”.

PINHEIRO, V.D.; COELHO, R.D.; SORIA, L.G.T.; LOURENÇO, L.F. Previsão da produtividade do capim Tanzânia em função da unidade fototérmica e adubação nitrogenadas. Sciencia Agrícola (no prelo).

PINTO, L.F.M. Dinâmica do acúmulo de matéria seca em pastagens de Cynodon spp. Submetidas a pastejo. Piracicaba, 2000. 124 p. Teses (mestrado) - Escola Superior de Agricultura “Luiz de Queiroz”, Universidade de São Paulo.

PRIMAVESI, O., PRIMAVESI A.C., LUCIANO, A., CANTARELLA, H., SILVA, A.G. Eficiência agronômica de uréia aplicada superficialmente em pastagem de capim coastcross. REUNIÃO ANUAL SOCIEDADE BRASILEIRA DE ZOOTECNIA, 38 . Piracicaba, 2001a. IN: A produção animal na visão dos brasileiros: Anais. Piracicaba: SBZ, 2001b. p.327-362. 
PRIMAVESI, O.; CORRÊA, L. de A.; PRIMAVESI A.C.; CANTARELLA, H.; CANTARELLA, H.; SILVA, A.G da; FREITAS. A.R. de. Adubação com uréia em pastagem de Cynodon dactylon cv Coastcross sob manejo rotacionado: eficiência e perdas. São Carlos: Embrapa - Pecuária Sudeste. 2001b, 42p. (Circular técnica, 30).

PRIMAVESI, O.; PRIMAVESI A.C.; CARMARGO, A.C. Conhecimento e controle, no uso de corretivos e fertilizantes, para manejo sustentável de sistemas intensivos de produção de leite de bovinos a pasto. Verde Agricultura, v. 74, n.2, p. 249-265, 1999.

QUEIROZ, NETO, F.; MARTHA JÚNIOR, G.B. PENATI, M.A. et al. Impact of increasing nitogem fertilizer rates upon na irrigated Tanzania grass pasture. 1. Dry matter yield. (compact disc). In: INTERNATIONAL GRASSLAND CONGRESS, 19., São Pedro, 2001. Proceeding. São Pedro: FEALQ, 2001.

RASSINI, J.B. Avaliação das respostas das forrageiras Tanzânia (Panicum maximum) e capim Elefante (Pennisetum purpureum) à irrigação na região Sudeste do Brasil. (compact disc). In: REUNIÃO ANUAL SOCIEDADE BRASILEIRA DE ZOOTECNIA, 34., Recife, 2002. Anais. Recife: SBZ, 2002.

REICHARDT, K.; LIBARDI, P.L.; MEIRELLES, N.M.F.; FERREIRA, F.F.H.; ZAGATTO, E.A.G.; MATSUI, E. Extração e análise de nitratos em solução de solo. Revista Brasileira de Ciencia do Solo, v. 1, p.130-132, 1977.

ROLIM, F. A. Estacionalidade de produção de forrageiras. In: Peixoto, A.M.; Moura, J.C. de; Faria, V. P. de (Ed.) Pastagens - fundamentos da exploração racional. - 2 ed. Piracicaba: FEALQ, 1994. p.533-565. (Série atualização em zootecnia, 10). 
SANTOS, P.M. Controle do desenvolvimento das hastes do capim Tanzânia: um desafio. Piracicaba, 2002. 98 p. Teses (Doutorado) - Escola Superior de Agricultura “Luiz de Queiroz”, Universidade de São Paulo.

SANTOS, P.M.; BALSALOBRE, M.A.A.; CORSI, M. Efeito da freqüência de pastejo e da época do ano sobre a produção e a qualidade de Panicum maximum cvs. Tanzânia e Mombaça. Revista Brasileira de Zootecnia, v.28, p.244-249, 1999.

SCHULZ,A. Phloem transport and differential unloading in pea seedlings after source and sink manipulations. Planta, v.192, p.239-248, 1994.

SANTOS, P. M. Estudo de algumas características agronômicas de Panicum maximum Jacq cvs. Tanzânia e Mombaça para estabelecer seu manejo. Piracicaba, 1997. 62p. Dissertação (Mestrado) - Escola Superior de Agricultura "Luiz de Queiroz" , Universidade de São Paulo.

SANTOS, P. M. Controle do desenvolvimento das hastes no capim Tanzânia : um desafio. Piracicaba, 2002. 98p. Tese (Doutorado) - Escola Superior de Agricultura "Luiz de Queiroz", Universidade de São Paulo.

SENTELHAS, P.C.; PERERIRA, A.R.; ANGELACCI, L.R. Meteorologia agrícola. Piracicaba: ESALQ, 1999, 125 p.

SORIA, L.G.T. Produtividade do capim Tanzânia Panicum maximum Jacq. cv. Tanzânia em função da lâmina de irrigação e adubação nitrogenada. Piracicaba, 2002. 170 p. Tese (Doutorado) - Escola Superior de Agricultura “Luiz de Queiroz”, Universidade de São Paulo. 
TASHIMA, H. Influência dos níveis de água e teor de potássio no desenvolvimento vegetativo e na produtividade de alfafa (Medicago sativa, L.). Botucatu, 1995. 76p. Dissertação de (Mestrado). Faculdade de Ciências Agrícolas, Universidade Estadual Paulista "Júlio de Mesquita F”".

TATIZANA, S.A. Um modelo conceitual de simulação da produção de gado de corte. Piracicaba, 1995. 95p. Dissertação (Mestrado) - Escola Superior de Agricultura "Luis de Queiroz”, Universidade de São Paulo.

TURNER, N.C.; BEGG, J.E. Responses of pasture plants to water deficits. In: WILSON, J.E. (ed.) Plants relations in pastures. Commonwealth scientific and industrial research organization. E. Melbourne, 1978, p.50-66.

VICENTE-CHANDLER, J. Intensive grassland management in Puerto Rico. Revista da Sociedade Brasileira de Zootecnia, v.2, n.2, p.173-215, 1973.

VIEIRA, J.M.; KICHEL, A.N. Estabelecimento e recuperação de pastagens de Panicum maximum. In: SIMPÓSIO SOBRE MANEJO DA PASTAGEM., 12., Piracicaba, 1995. Anais. Piracicaba: FEALQ, 199. p.147-196.

Van RAIJ, B.; CANTARELlA, H.; QUAGGIO, J.A.; FURLANI, A.M.C. Recomendações de adubação e calagem para o Estado de São Paulo. IAC, 1997. (Boletim técnico, 100)

VILLA NOVA, N.A., BARIONI, L.G., PEDREIRA, C.G.S., PEREIRA, A.R. Modelo para previsão da produtividade do capim elefante em função de temperatura do ar, fotoperído e freqüência de desfolha. Revista Brasileira de Agrometeorologia, v.7, n.1, p.75-79, 1999. 
VILELA, L.; GUERRA, A.L.; LEITE, G.G. Manejo da irrigação e do nitrogênio em gramíneas forrageiras no Cerrado. Planaltina: Embrapa Cerrados, 2003. 21p. (Relatório Final de Pesquisa - Projeto 01.2000.347-03).

WERNER, J.C. Adubação de pastagens. Nova Odessa: Instituto de Zootecnia, 1984. 49 p. (Boletim técnico, 18).

WERNER, J.C.; PEDREIRA, J.V.S.;CAIELE, E.L. Estudo de parcelamento e níveis de adubação nitrogenada com capim pangola (Digitaria decumbens Stent). Boletim da Indústria animal, v.24, p.147-151, 1967.

WHITEHEAD, D.C. Volatilization of ammonia. In: Whitehead, D.C. Grassland nitrogen. Wallingford: CAB International, 1995. p.152-179. 